IBIMA Publishing

International Journal of Renewable Energy \& Biofuels

http://www.ibimapublishing.com/journals/IJREB/ijreb.html

Vol. 2014 (2014), Article ID 506376, 56 pages

DOI: $10.5171 / 2014.506376$

Research Article

\title{
A Comprehensive Review on Biomass Torrefaction
}

\author{
Daya Ram Nhuchhen ${ }^{1}$, Prabir Basu ${ }^{1}$ and Bishnu Acharya ${ }^{2}$ \\ ${ }^{1}$ Mechanical Engineering, Dalhousie University, Morris Street, Halifax, Canada \\ ${ }^{2}$ Greenfield Research Incorporated, Bayview Road, Halifax, Canada
}

Correspondence should be addressed to: Daya Ram Nhuchhen; dayashyad@hotmail.com

Received Date: 30 October 2013; Accepted Date: 9 January 2014; Published Date: 30 April 2014

Academic Editor: Mingjie Jin

Copyright (C) 2014 Daya Ram Nhuchhen, Prabir Basu and Bishnu Acharya. Distributed under Creative Commons CC-BY 3.0

\begin{abstract}
Biomass is a versatile energy resource that could be used as a sustainable energy resource in solid, liquid and gaseous form of energy sources. Torrefaction is an emerging thermal biomass pretreatment method that has an ability to reduce the major limitations of biomass such as heterogeneity, lower bulk density, lower energy density, hygroscopic behavior, and fibrous nature. Torrefaction, aiming to produce high quality solid biomass products, is carried out at 200-300 ${ }^{\circ} \mathrm{C}$ in an inert environment at an atmospheric pressure. The removal of volatiles through different decomposition reactions is the basic principle behind the torrefaction process. Torrefaction upgrades biomass quality and alters the combustion behavior, which can be efficiently used in the co-firing power plant. This paper presents a comprehensive review on torrefaction of biomass and their characteristics. Despite of the number of advantages, torrefaction is motivated mainly for thermochemical conversion process because of its ability to increase hydrophobicity, grindability and energy density of biomass. In addition to this, torrefied biomass could be used to replace coal in the metallurgical process, and promoted as an alternative of charcoal.
\end{abstract}

Keywords: Biomass Pretreatment, Torrefaction, Properties, Advantages.

\section{Introduction}

The world primary energy demand, reported as 505 quadrillion BTU in 2008, is expected to increase by $53 \%$ in 2035 (IEO, 2011). Energy security and environmental sustainability are the major emerging issues in the world that can only be addressed through the diversification in the energy resources and clean fuels. The promotion of indigenous renewable energy sources and the low carbon fuels could be a win-win solution while addressing issues of the global warming and climate change. Kyoto Protocol, legally binding EU 20-2020 targets, and volatility of oil prices have encouraged the global community to reduce the dependence on oil and replace it with a clean and renewable energy resources (Deutmeyer et al., 2012). Biomass energy - a renewable energy could be a good candidate for replacement of fossil fuels. It can be used in three forms, such as solid (briquette, pellet, char), liquid (ethanol, biodiesel), and gaseous (producer gas, biogas) (Koh and Hoi, 2003).

Cite this Article as: Daya Ram Nhuchhen, Prabir Basu and Bishnu Acharya (2014), "A Comprehensive Review on Biomass Torrefaction," International Journal of Renewable Energy \& Biofuels Vol. 2014 (2014), Article ID 506376, DOI: 10.5171/2014.506376 
A blanket use of any type of biomass may not be good for a sustainable source. For example, the rapid increase in food-based fuel has strained the food supplies in some countries. Lignocellulose biomass on the other hand free from this problem is an alternative source of bioenergy. The use of lignocellulosic biomass has increased significantly in producing bio-oil and synthetics chemicals. The lignocellulosic biomass, in spite of all its positive attributes, is associated with the different shortcomings like structural heterogeneity, non-uniform physical properties, low energy density, hygroscopic nature, and low bulk density. These limitations create difficulties in transportation, handling, storage, and conversion processes (Arias et al., 2008; Phanphanich and Mani, 2011; Medic et al., 2011; Uemura et al., 2011; Wannapeera et al., 2011). These properties limit the use of biomass to replace fossil fuels for energy production. Therefore, biomass needs to be pretreated before it can be used in any thermochemical conversions processes. Torrefaction is emerging as such pretreatment method that removes many of the above limitations associated with raw biomass.

This paper presents a comprehensive review of biomass torrefaction. Starting with an introduction in the first section, and an overview of biomass properties is presented in section 2 . A detailed review of dry torrefaction is presented in section 3 . The effect of torrefaction in different conversion process is discussed in section 4. The explosivity of torrefied biomass, commercial development, potential application of torrefied biomass, and a sustainability approach on torrefaction technology are presented in subsequent sections. Finally, conclusions are presented in section 9.

\section{Overview of Biomass}

Biomass is any organic materials derived from plants or animals, excluding materials that take millions of years to produce such as: coal or petroleum (Basu, 2010). The energy produced from biomass does not contribute acid rain gases due to the negligible sulfur, and nitrogen contents of biomass (Demirbas, 2008). Biomass stores sun's energy through photosynthesis process. Human being extracts the stored energy with the help of different conversions routes as shown in Fig. 1. It is noted that biomass can be used directly for energy conversion or upgraded into superior energy carriers such as bio-char, producer gas, and bio-oil through different routes like pyrolysis, gasification, fermentation, transesterification, and anaerobic digestion.

According to the Energy Statistics of International Energy Agency 2009, biomass energy contributed around $10 \%$ of the world's total primary energy supply (IEA, 2009). Biomass can be used as a feedstock for liquid or a gaseous fuel for the transport sector through thermochemical and biological routes, and is therefore considered as a promising renewable energy resource (Demirbas, 2008). Table 1 presents a classification of biomass types by their sources. Forestry and agriculture sector are two main resources as the primary source of biomass. Industry and waste are the secondary sources, as these are derived from biomass from primary source.

Traditional use of biomass has been limited to cooking and heating purpose, which has caused adverse impacts such as land degradation and desertification. However, modern use of biomass - a high quality energy carrier converted from raw biomass - for electricity, and heat production can substantially reduce emissions from the conventional power plants (Hoogwijk et al., 2005). This ability to convert raw biomass into convenient energy carriers increases the interest on biomass use for energy purpose, especially the lignocellulosic biomass. 


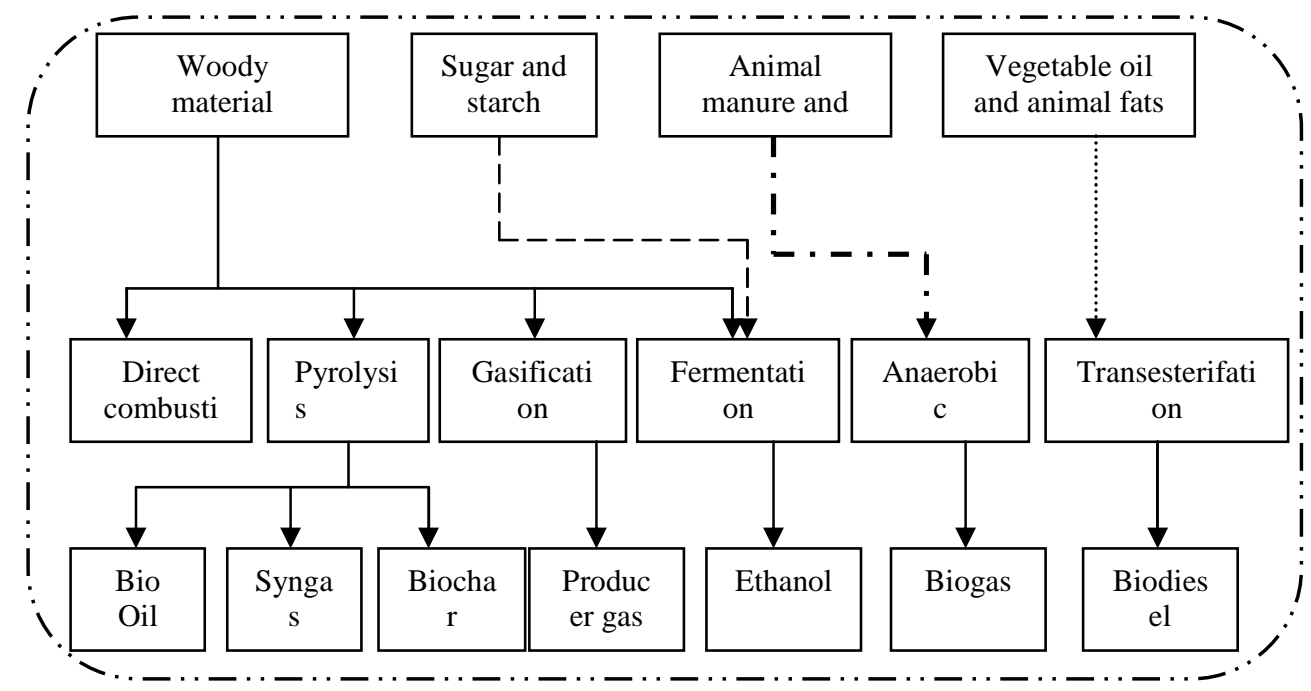

Figure 1: Biomass Energy Conversion Routes

Table 1: General Classification of Biomass Resources

\begin{tabular}{|c|c|c|}
\hline $\begin{array}{l}\text { Supply } \\
\text { sector }\end{array}$ & Type & Examples \\
\hline \multirow{2}{*}{ Forestry } & - Dedicated forestry & $\begin{array}{l}\text { - Short rotation plantations (Willow, poplar and } \\
\text { eucalyptus) }\end{array}$ \\
\hline & $\begin{array}{l}\text { - Forestry by } \\
\text { products }\end{array}$ & - Wood blocks and wood chips from thinning \\
\hline \multirow{6}{*}{ Agriculture } & $\begin{array}{l}\text { - Dry lingo-cellulosic } \\
\text { energy crops }\end{array}$ & $\begin{array}{l}\text { - Herbaceous crops (Miscanthus, reed canary } \\
\text { grass and giant reed) }\end{array}$ \\
\hline & \multirow{3}{*}{$\begin{array}{l}\text { - Oil, sugar and } \\
\text { starch energy crops }\end{array}$} & $\begin{array}{l}\text { - Oil seeds for methylesters (Rape seed and } \\
\text { sunflowers) }\end{array}$ \\
\hline & & $\begin{array}{l}\text { - Sugar crops for ethanol (Sugarcane and sweet } \\
\text { sorghum) }\end{array}$ \\
\hline & & - Starch crops for ethanol (Maize and wheat) \\
\hline & $\begin{array}{l}\text { Agriculture } \\
\text { residues }\end{array}$ & - Straw, prunings from vineyards and fruit trees \\
\hline & - Livestock & - Wet and dry manure \\
\hline \multirow{2}{*}{ Industry } & \multirow{2}{*}{ - Industrial residues } & - Industrial waste wood, sawdust from sawmills \\
\hline & & - Fibrous vegetable waste from paper industries \\
\hline \multirow{5}{*}{ Waste } & - Dry lingo-cellulosic & $\begin{array}{l}\text { - Residues from parks and gardens (Prunings and } \\
\text { grasses) }\end{array}$ \\
\hline & \multirow{4}{*}{$\begin{array}{l}\text { - Contaminated } \\
\text { waste }\end{array}$} & - Demolition wood \\
\hline & & - Organic fraction of municipal solid waste \\
\hline & & - Biodegradable landfill waste, landfill gas \\
\hline & & - Sewage sludge \\
\hline
\end{tabular}

Source: Adapted from EUBIA (2007)

\section{The Structure of the Lignocellulosic Biomass}

Biomass can be lignocellulosic or nonlignocellulosic materials. The lignocellulosic material is the non-starch and fibrous part of the plants that consists mainly of cellulose, hemicellulose, and lignin (Basu, 2010). The non-lignocellulosic material, on the other hand, is noncellulosic organic material, which is used mainly for nutritional purpose. Sugar, starch, protein, and fat content of any crops are the non-lignocellulosic materials. These 
materials can be easily hydrolyzed to produce upgraded bioethanol (Doelle, 2012.).

An efficient conversion of lignocellulosic biomass needs better understanding of the cell wall structure and their compositions. Plant's cell wall, which consists of four major macro components namely primary wall, secondary wall, plasma membrane, and middle lamella, are made of cellulose, hemicellulose, lignin, and some extractives as shown in Fig. 2. Such plants are referred as the lignocellulosic material (Foster et al., 2010). These polymers give a rigid structure to the plant. Table 2 presents a comparison of range of these polymer constituents for some principal types of lignocellulosic materials. Here we note that biomass from animal waste is rather poor in these three polymers. As such their classification under lingo-cellulose, biomass is questionable. A brief introduction to the polymeric constituents of the plant cell is presented here.

\section{$\underline{\text { Lignin }}$}

Lignin is a three-dimensional polymer made up of predominantly $\mathrm{C}-\mathrm{O}-\mathrm{C}$ and $\mathrm{C}-\mathrm{C}$ linkages (Rowell, 2005). Lignin could be of different types such as: (i) lignin of hardwood (angiosperms); (ii) lignin of softwood (gymnosperms); and (iii) lignin of grasses (non-woody or herbaceous crops) (Buranov and Mazza, 2008).

Lignin is the generic term for a large group of aromatic polymers (Vanholme et al., 2010), Lignin is a co-polymer of three phenyl propane monomer units (monolignols) such as para-coumaryl alcohol, coniferyl alcohol, and sinapyl alcohol (Fig. 3). $\beta$-0-4-aryl ether bonds are the most common coupling linkages in the polymerization process of lignin monomers (Pandey and Kim, 2011). Lignin thermally decomposes over a broad temperature range, because various oxygen functional groups from its structure have different thermal stabilities, their scission occurring at different temperatures (Brebu and Vasile, 2009). The lignin is thermally stable over a wide temperature range from $100{ }^{\circ} \mathrm{C}$ to $900{ }^{\circ} \mathrm{C}$ (Yang et al., 2007). Thus, in the torrefaction process, lignin remains less modified and a biomass with higher lignin content yields more solid products.

\section{Cellulose}

Cellulose is a long chain polymer of glucose that can establish intra-molecular and inter-molecular hydrogen bonds. Cellulose $\left(\mathrm{C}_{6} \mathrm{H}_{10} \mathrm{O}_{5}\right)_{\mathrm{n}}$ is characterized by its large molecular weights of 500,000 units monomers (Basu, 2010). D-glucoses are the major constituents of cellulose, which are linked by $\beta-(1 \rightarrow 4)$-glucosidic bonds (Rowell, 2005). The structure of the cellulose is crystalline in nature that has higher packing density that helps to increase the strength of biomass structure. Figure 4 shows the typical chemical structure of cellulose, showing different hydroxyl groups in the chain. The hydroxyl group increases its ability of forming hydrogen bonds that is responsible for hygroscopic behavior of raw biomass. The hygroscopic nature of cellulose increases the gap between cellulose chains, resulting in the swelling of biomass. Thus, during the thermal treatment period, the solid product undergoes the shrinkage phenomena, causing dimensional variations.

\section{Hemicellulose}

Hemicelluloses are composed mainly of heteropolysaccharides such as hexoses (glucose, mannose, and galactose) and pentoses (xylose and arabinose) (Pollex et al., 2012). Hemicelluloses are polysaccharides of plant's walls, which strengthen the primary cell walls. Xyloglucans, xylans, mannans, glucomannans and $\beta-(1 \rightarrow 3,1 \rightarrow 4)-$ glucans are important constituents in the hemicellulose (Scheller and Ulvskov, 2010). It has random amorphous structure, and is the weakest constituent of biomass cells (Basu, 2010). Hemicellulose is made predominantly of acetyl- and methylsubstituted groups (Rowell, 2005). These groups are responsible for releasing light volatiles gases such as $\mathrm{CO}_{2}$ and $\mathrm{CO}$, upon low temperature thermal pretreatment. Hemicellulose, which has a lower degree of polymerization compared to cellulose, undergoes to substantial thermal 
degradation, and has significant effect on mass yield in the torrefaction process. Figure 5 shows the structure of hemicellulose in a hardwood.

\section{Biomass for Energy Generation}

With the growing energy demand and emerging environmental issues, the new and clean energy sources are being explored to avoid possible damages from global warming and climate change. Biomass is widely distributed around the world, and it is often available at relatively low price. It could therefore become the world's important renewable energy resource. Biomass can help replace the fossil fuels in transportation, and the power generation sector because it has the ability of producing biofuels such as biodiesel, methanol, and hydrogen through the Fisher-Tropsch Synthesis process (Ptasinski, 2008). However, some of its inherent limitations like low energy density, fibrous nature, and hygroscopic nature, use of biomass for energy generation have so far been restricted. Currently, co-firing technology has gained wide acceptance for reducing fossil fuel consumption and corresponding emission in thermal power plants by replacing a part of fossil fuel with biomass. But the share of biomass in the mix has been limited to 5$10 \%$. A higher percentage is not economically feasible unless the properties of biomass are upgraded.

\section{Shortcomings of Biomass as Energy Source}

Despite all its advantages, biomass has some shortcomings that often create difficulties in its wide scale use as an energy source. Compared to other fuels like coal, biomass has higher oxygen content, lower calorific value, lower bulk density, higher hygroscopic nature, and higher moisture content. Thus, biomass faces some technical challenges in energy conversion systems (van der Stelt et al., 2011).
The low bulk density of raw biomass causes storage and handling problems. It also reduces the energy density of biomass that in turn increases the volume of biomass feed into a conversion system to produce a given amount of power. The low bulk density of biomass also increases the cost associated with storage, transportation, and handling of materials at the conversion plant (Arias et al., 2008; Tumuluru et al., 2011).

The higher oxygen content reduces the heating value and thereby makes it a lower-grade fuel. The higher oxygen content is responsible for producing a large volume of the flue gas during combustion (van der Stelt et al., 2011) that requires much bigger size of plants and auxiliary equipment.

The higher moisture content (45-60\%) of raw biomass has significant negative impact on the bioenergy production and its consumption chain (Ratte et al., 2011). Though, moisture adds some benefits in biological conversion methods, it remains as one of the major obstacles for thermochemical conversion. A modest amount of moisture, however, shows some benefits in the gasification process in which the steam produced from the moisture assists in increasing the hydrogen concentration in the producer gas (Acharjee et al., 2011). At the same time, higher moisture also decreases the overall gasification temperature, resulting in a lower gasification efficiency and higher tar formation. Moist biomass on the other hand also shows a greater tendency to undergo the natural decomposition. This alters the physical, chemical, and microbiological properties and degrades the fuel quality (Tumuluru et al., 2011). A wet biomass, when stored could lose some solid mass due to the microbial decaying process (Medic et al., 2011). 


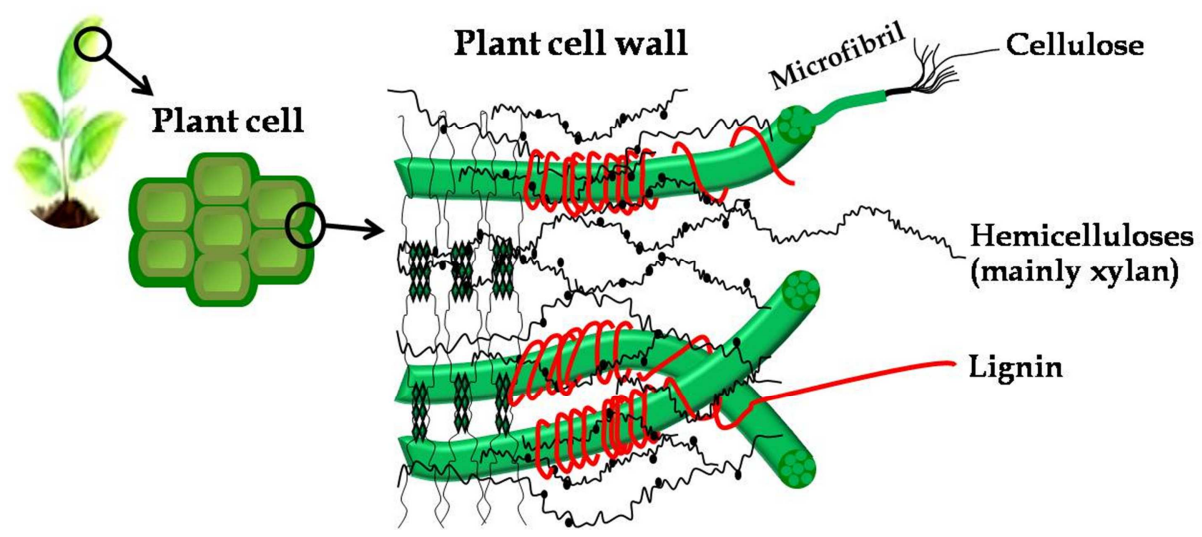

Figure 2: Structure of Primary Cell Wall of Plant Cell Source: Adapted from Tomme et al. (1995)

Table 2: Polymeric Constituents of Different Biomass Sources

\begin{tabular}{|l|l|l|l|}
\hline Lignocellulosic materials & Cellulose (\%) & Hemicellulose (\%) & Lignin (\%) \\
\hline Hardwood stems & $40-55$ & $24-40$ & $18-25$ \\
\hline Softwood stems & $45-50$ & $25-35$ & $25-35$ \\
\hline Nut shells & $25-30$ & $25-30$ & $30-40$ \\
\hline Corn cobs & 45 & 35 & 15 \\
\hline Grasses & $25-40$ & $35-50$ & $10-30$ \\
\hline Paper & $85-99$ & 0 & $0-15$ \\
\hline Wheat straw & 30 & 50 & 15 \\
\hline Sorted refuse & 60 & 20 & 20 \\
\hline Leaves & $15-20$ & $80-85$ & 0 \\
\hline Cotton seed hairs & $80-95$ & $5-20$ & 0 \\
\hline Newspaper & $40-55$ & $25-40$ & $18-30$ \\
\hline $\begin{array}{l}\text { Waste papers from chemical } \\
\text { pulps }\end{array}$ & $60-70$ & $10-20$ & $5-10$ \\
\hline Primary wastewater solids & $8-15$ & & $24-29$ \\
\hline Swine waste & 6 & NA & NA \\
\hline Solid cattle manure & $1.6-4.7$ & 28 & $2.7-5.7$ \\
\hline Coastal Bermuda grass & 25 & $1.4-3.3$ & 6.4 \\
\hline Switch grass & 45 & 35.7 & 12 \\
\hline Source: Adapted from Sun and Cheng $(2002)$ & 31.4 & \\
\hline
\end{tabular}




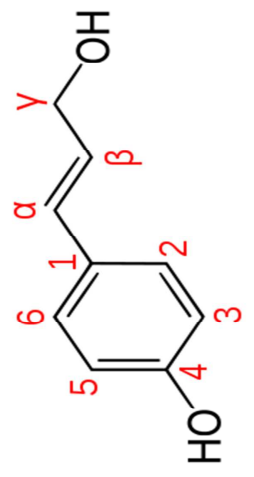

(a)

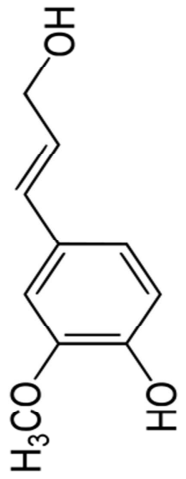

(h)

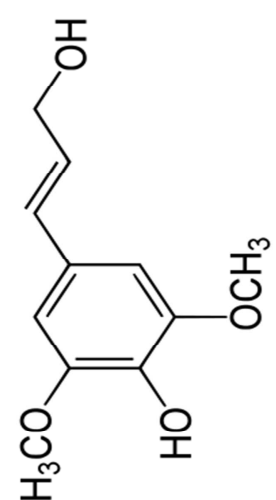

$(n)$

Figure 3: Three Major Monomers of Lignin: (a) Paracoumaryl Alcohol; (b) Coniferyl Alcohol; and (c) Sinapyl Alcohol

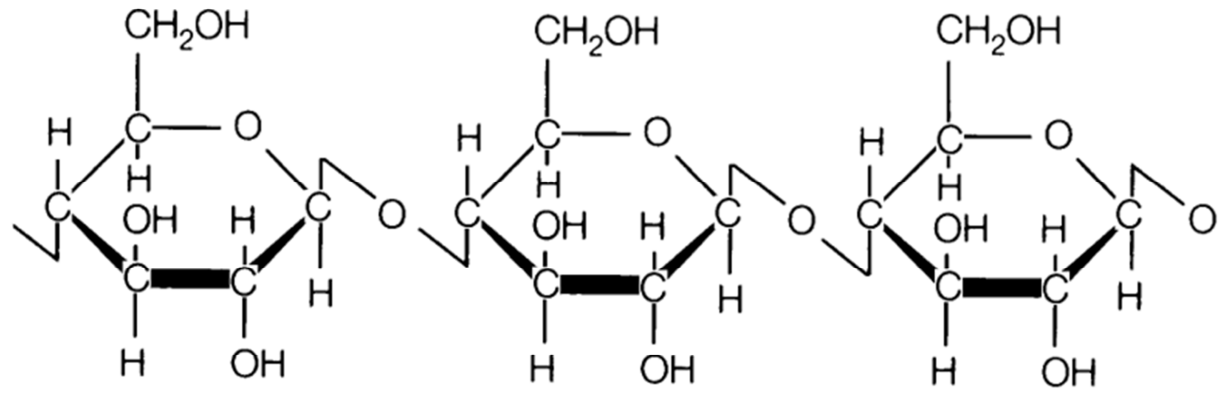

Figure 4: Structure of Cellulose Compositions

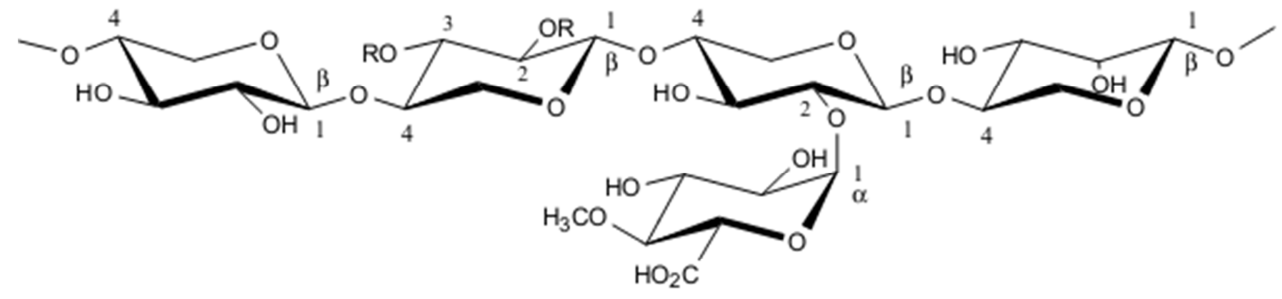

Figure 5: The Structure of Hemicelluloses (Xylan)

The hygroscopic nature is another major drawback of biomass. Though, biomass can be dried before its use, the hygroscopic nature makes it to reabsorb the moisture from the surrounding atmosphere even if it is stored indoors.

The fibrous nature of biomass increases the difficulties in pulverizing it into a fine powder as required for co-firing in pulverized coal fired boiler. This results in higher grinding costs, or reduces the generation capacity of the plant (Ratte et al., 2011; Wannapeera et al., 2011). The fibrous nature of biomass not only increases its grinding cost, but it is also responsible for the inconsistency in the particle sizes (Tumuluru et al., 2011). The pulverized particles from raw biomass are coarse and slender in nature $(100-10 \mathrm{~mm})$ with a low sphericity values (Phanphanich and Mani, 2011). Such lower sphericity reduces its flowability, reducing the performance of the entrained flow gasifier (Melkior et al., 2011). 


\section{Biomass Pretreatment Methods}

The above limitations of biomass are hindering the wide-scale use of biomass. This limitation can be reduced to some extent by pretreatment. Pretreatment alters the biomass such that enzymatic hydrolysis of cellulose, and hemicellulose can be achieved more rapidly and with a greater yield (Harmsen et al., 2010). The pretreatment also enhances its physical properties making it suitable for use in the existing energy conversion systems. However, for such process to be commercially viable, the technology should be well developed and economical feasible. Biomass pretreatment methods are classified into five categories: a) Chemical, b) Mechanical, c) Thermal, (d) Hydrothermal (wet), and (e) Biological. These pretreatment methods facilitate biomass conversion process, increasing the economical and environmental viability of biomass use (Almeida et al., 2010; Harmsen et al., 2010). The study on the chemical, mechanical, and hydrothermal pretreatment of biomass is beyond the scope of this paper; only a short discussion on them is presented here.

\section{Chemical or Hydrolysis}

The primary goal of the chemical pretreatment is to improve the biodegradability of cellulose in biomass by removing the lignin and hemicellulose (Zheng et. al. 2009). The Common chemical pretreatment techniques are catalyzed steam-explosion, acid, alkaline, ammonia fiber/freeze explosion, organosolv, $\mathrm{pH}$ controlled liquid hot water, and ionic liquids pretreatments. In ethanol production, the chemical pretreatment separates lignin and hemicellulose, and enhances the hydrolysis of cellulose, increasing ethanol production (Sun and Cheng, 2002). The chemical pretreatment also changes the morphological structure, as well as the arrangement of different functional groups. For example, an alkali based on chemical pretreatment reduces the degree of polymerization, disturbs lignin structure, and breaks the linkages in different cell compositions (Agbor et al., 2011).

\section{Mechanical}

The mechanical pretreatment brings about only physical change of biomass. Milling, extrusion, and grinding are the major mechanical pretreatment methods (Harmsen et al., 2010). Milling increases the accessible surface area of biomass for it conversion processes. A comparative study of sugar yield of two mechanically pretreated biomass namely extrusion and grinding, found that the extrusion treated biomass shows higher sugar yield compared to the grinding for wheat bran (Lamsal et al., 2010). Similarly in the screw press pretreatment method, an increase in the pressure and temperature improves the extent of softening of biomass and, reduces the moisture level. However, mechanically pretreated biomass does not increase the hydrophobicity of biomass. One very poplar pretreatment method is pelletization, but it does not necessarily increases the surface area. During pelletization, the ground biomass is compressed with at a specified temperature into a regular shape. Such regular greatly increases the handling ease of biomass, but it does not have the ability to avoid the moisture reabsorption capacity.

\section{Thermal}

The thermal pretreatment is a slow heating process in which biomass releases its volatiles. This process modifies the physical, structural, and chemical properties of biomass. Torrefaction, which is a thermal pretreatment method, produces a carbon rich solid product. This process is different from the drying, because in addition to removal of moisture it involves some chemical transformations within the polymer constituents of the cell wall. These transformations reduce the mechanical strength of the biomass, and produce more brittle and less fibrous products. The thermal pretreatment also increases biodegradability of waste biomass in the biological conversion process. For instance, the thermally pretreated biomass at $70{ }^{\circ} \mathrm{C}$ and $90{ }^{\circ} \mathrm{C}$ increased the anaerobic biodegradability in a methane production process by $24 \%$ and 
$48 \%$, respectively when compared with the raw biomass (Gonzalez-Fernandez et al., 2012). The thermal treatment enhances the fuel flexibility making a wide range of fuels suitable for firing in pulverized coal fired plant. For example, the microalgae produced, using the flue gas from a thermal power plant can be made suitable for cofiring in a PC boiler by the torrefaction process (Wu et al., 2012).

The thermal pretreatment, which mainly refers to the torrefaction process, can be divided into a dry and wet (hydrothermal) torrefaction (Yan et al., 2009). Table 3 gives different characteristics of the wet and dry torrefaction. The dry torrefaction is usually carried out in a dry inert environment and is described in more details in section 3 .

\section{The Hydrothermal}

The hydrothermal carbonization may be defined as a thermochemical conversion process in which biomass is kept with water under a high pressure at moderate temperatures $\left(180-230^{\circ} \mathrm{C}\right.$ ) (Roman et al., 2012). The hydrothermal or the wet torrefaction uses either compressed water in a liquid form (Yan et al., 2010) or water mixed with acetic acid and lithium chloride (Lynman et al., 2011). The hydrothermal (wet) torrefier is an innovative reactor that could be used for treating a wet biomass such as animal manures, human waste, sewage sledges, municipal solid waste, aquaculture residues and microalgae. This overcomes the major limitation of dry torrefaction where the moisture content is limited to 15\% (Koppejan et al., 2012).

The hydrothermal torrefaction is usually carried out in an autoclave or a specially made custom steel reactor. The hydrothermal torrefaction of biomass is mainly characterized by its ability to bring instability in the structure of lignocellulosic biomass, initializing the decomposition reactions at a low temperature. Hydrolysis is the primary reaction that alters physical structure of biomass in the hydrothermal torrefaction. Decarboxylation, dehydration, condensation, and aromatization are the four major reactions of the hydrothermal torrefaction (Funke and Ziegler, 2010).

The hydrothermal torrefaction can increase the energy density of biomass by up to $36 \%$ above that for the raw biomass (Yan et al., 2010). Though, the hydrothermal torrefaction adds more steps such as filtration and drying process compared to the dry torrefaction, its ability to treat the wet biomass increases the fuel flexibility making it more commercially attractive. For example, hydrothermal torrefaction can pretreat digested sludge from the anaerobic digester, increasing waste to the energy recovery from the agriculture residue (Oliveira et al., 2013). An aqueous waste stream from hydrothermal torrefaction contains substantial level of potentially valuable organic chemicals, such as sugars, furans, furfurals, and organic acids. The solution can also be used as a nutritional product that is applicable in growing algae (Jena et al., 2011). One potential major attraction of hydrothermal torrefaction is that it could lead to reduction in corrosion, and agglomeration causing elements in the biomass. A preliminary work of Dutta (2013) found an evidence of the major reduction in sodium and potassium content in the torrefied biomass. 
Table 3: The Characteristics of the Thermal Pretreatment Methods

\begin{tabular}{|c|c|}
\hline Thermal pretreatment methods & Characteristics \\
\hline Wet torrefaction & $\begin{array}{l}\text { - } \text { Temperature ranges: } 200-260^{\circ} \mathrm{C} \\
\text { - } \text { Media: hot compressed water } \\
\text { - } \text { Pressure range: } 200-700 \mathrm{psi} \\
\text { - } \text { Biomass sample size: } 2 \mathrm{~g} \\
\text { - } \text { Residence time: } 5 \mathrm{~min} \\
\text { - } \text { Cooling process: rapidly immersion in an } \\
\text { ice bath } \\
\text { - } \text { Need filtration and evaporation process } \\
\text { - } \text { Higher energy density than dry torrefaction }\end{array}$ \\
\hline Dry torrefaction & $\begin{array}{l}\text { - Temperature ranges: } 250-300^{\circ} \mathrm{C} \\
\text { - Media: inert gas (Nitrogen) } \\
\text { - Pressure: atmospheric pressure } \\
\text { - Biomass sample: } 5 \mathrm{~g} \\
\text { - Residence time: } 80 \mathrm{~min} \\
\text { - Cooling process: flowing nitrogen/indirect } \\
\text { water cooling }\end{array}$ \\
\hline
\end{tabular}

Source: Adapted from Yan et al. (2009)

Another major advantage of hydrothermal torrefaction is its ability to produce an energy dense product in a relatively short period (5 minutes) of residence time (Coronella et al., 2012), while that for dry torrefaction it is between 30-60 minutes. The heat transfer rate in aqueous media is very high (Hoekman et al., 2013). This reduces the residence time of the hydrothermal torrefaction compared to the dry torrefaction. For instance, Yan et al. (2010) is able to perform the wet torrefaction of loblolly pine only within 5 minutes of residence time. In addition to this, the high working pressure around 20 bars reduces the carbon loss during the pretreatment (Libra et al., 2011). The solid product yield is further enhanced by the recondensation reactions in aqueous solution. The re-condensation of liquid increases the carbon content in the torrefied biomass under the hydrothermal torrefaction. Thus, a hydrothermal torrefaction could produce a higher solid yield. The carbon loss per unit mass of feedstock increases with the amount of water mixed in the hydrothermal torrefaction, causing to a low net energy yield (Libra et al., 2011). For instance, a typical study on hydrothermal (wet) torrefaction results $10 \%$ reduction in energy yield compared with that of a dry method under the similar operating conditions (Chen et al., 2012).
To widen the range of moisture in feedstock for torrefaction technology, the PCS biofuels of Canada developed a hydrothermal polymerization process. This system consists of a reactor with liquid catalyst in which biomass is kept under moderately high pressure at a temperature around $250 \stackrel{\circ}{\circ}$ for a certain period of time. Biomass inside the reactor undergoes series of chemical reactions, forming water, carbon dioxide, and solid biofuels. Depending upon the type of catalyst used, different compositions of biomass, which are soluble in the liquid catalyst, are liberated out. In addition to this, the ability to recycle the liquid catalyst using cascaded reactor systems could reduce the thermal energy required for the process. Using an appropriate and hazards free catalyst also helps to use an aqueous solution of catalyst as a natural nutritional fertilizer for growing crops (PCSB, 2013).

\section{The Biological Pretreatment}

The biological pretreatment uses microorganism to modify the chemical composition and the structure of the lignocellulose biomass for making it suitable for the enzymatic digestion. The microorganisms used are white and brown soft-rot fungi, and bacteria (Zheng et al., 2009). The white-rot fungi, a major degrader of wood in the forest ecosystems, 
are the most effective microorganisms for the biological pretreatment of lignocellulose biomass (Akin et al., 1995; Chaturvedi and Verma, 2013). The biological treatment process seems to be a promising technology, as it avoids the use of chemicals, consumes less energy, produces minimal byproducts, works at mild operating conditions, and does not harm environmental (Wingreini et al. 2005). However, the biological pretreatment process is very slow and it requires a large space and a controlled environment for the effective pretreatment, which makes the process costly compared to other pretreatment methods (Zheng et. al. 2009).

\section{Overview of Torrefaction}

Torrefaction is a partial pyrolysis of biomass which is carried out under atmospheric pressure in a narrow temperature range of $200-300{ }^{\circ} \mathrm{C}$, and under an inert environment (Bergman et al., 2005; Clausen et al., 2010; Medic et al., 2011; Prins et al., 2006). It produces three major products such as dark color solid products, yellowish color acidic aqueous products, and non-condensable gaseous products. Torrefaction is usually performed at a low heating rate, which gives a higher yield of solid product (Deng et al., 2009). Unlike pyrolysis, the major motivation of torrefaction is the maximization of the solid yield. Decomposition, devolatilization and depolymerization are the three major reactions that occur during the torrefaction process. This process releases condensable hydrocarbon, hydrogen, oxygen, and some carbon content from the biomass in the form of water, carbon monoxide, and carbon dioxide (Pach et al., 2002). During the torrefaction process, drying is considered to be a more destructive as it breaks inter- and intra-molecular hydrogen, $\mathrm{C}-\mathrm{O}$, and $\mathrm{C}-\mathrm{H}$ bonds (Tumuluru et al., 2011). This leads to emissions of hydrophilic and oxygenated compounds, forming a blackened hydrophobic energy dense product.

\section{Motivations for Torrefaction}

The main motive of torrefaction is to upgrade the fuel quality of biomass to make it more suitable for the thermochemical conversion. A torrefied biomass can be used in briquetting, pelletization, gasification, and co-firing thermal power plants (Bridgeman et al., 2010; Felfli et al., 2005; van der Stelt et al., 2011). The torrefaction of biomass destructs the tenacity and fibrous structure of the biomass, and also increases its energy density. Numerous studies concluded that the torrefied biomass can avoid many limitations associated with the raw biomass because it produces moisture free hydrophobic solid products (Acharjee et al., 2011), decreases $0 / C$ ratio (Prins et al., 2006), reduces grinding energy (Repellin et al., 2010; Phanphanich and Mani, 2011), enhances energy density (Yan et al., 2009), increases bulk density and simplifies storage and transportation (Bergman, 2005; Phanphanich and Mani, 2011), improves particle size distribution (Phanphanich and Mani, 2011), intensifies combustion with less smoke (Pentananunt et al.,1990), shifts combustion zone to the high temperature zone in a gasifier (Ge et al., 2013), and increases the resistance to the biological decay (Chaouch et al., 2010). Many of these improvements make the torrefied biomass more suitable than the raw biomass for co-firing in the conventional coal power plants, with minor modifications (Clausen et al., 2010).

The removal of volatiles (light gases) during the torrefaction leads to a decreased in $\mathrm{O} / \mathrm{C}$ ratio, and increased the energy density of the biomass. The losses of carbonyl and the carboxyl groups from cellulose, the carboxyl group from hemicellulose, and the aromatic ring and the methoxyl groups from lignin are the major sources of mass loss during this thermal treatment of biomass (Yang et al., 2007). These components have less energy content than the biomass as a whole. 
Thus, their loss increases the energy density of biomass after torrefaction. The increase in the energy density in the torrefied product may also be due to the higher fraction of lignin (heating value of $25 \mathrm{MJ} / \mathrm{kg}$ ), and a reduced fraction of hemicellulose and cellulose with heating value $18.6 \mathrm{MJ} / \mathrm{kg}$ (Gupta and Demirbas, 2010).

The hydroxyl group, which can establish ions and attract water molecules, is responsible for the hydrophilic behavior of biomass. The hydrophilic nature of biomass decreases as the torrefaction reduces the hydroxyl groups through decomposition reactions. The removal of hydroxyl groups also decreases the capability of forming hydrogen bonds that in turn reduces the moisture-absorbing capacity of biomass. This effect leads to the transformation of polar molecules into non-polar unsaturated molecules and produces a hydrophobic product.

The tenacious and fibrous nature of raw biomass established due to a complex structure of interlinked polymeric components increase the grinding cost of biomass. The heat applied during the torrefaction process modifies the complex structures of the interlinked polymeric components. It thus breaks down the hemicellulose matrix, and depolymerizes the cellulose structure, resulting in a decrease in the fiber length (Bergman and Kiel, 2005). The decomposition of the hemicellulose matrix produces mainly a light volatiles gases such as $\mathrm{CO}_{2}, \mathrm{CO}, \mathrm{CH}_{4}$ and traces of $\mathrm{H}_{2}$ (Prins et al., 2006a). The decomposition and the depolymerization of the macro-polymeric components to the micro-monomers, which decreases fiber length as well as increases porosity, increase the grindability of biomass. The improvement in the grindability reduces slenderness in the ground particles, producing a uniform particle size distribution suitable for co-firing power plants.

\section{The Mechanism of Torrefaction}

In the torrefaction process, the major changes and the transformation occurring inside the biomass can be predicted mainly by understanding the behavior of three polymeric constituents. For example, the hemicellulose - a highly reactive component - undergoes decomposition and devolatilization, and contributes a major part of mass loss in the torrefaction process. Therefore, the biomass materials with a high hemicellulose content have a lower solid product yield compared with that of the biomass with a low hemicellulose. The acetic acid and the methanol from acetoxy- and methoxygroups are the major constituents of the volatiles gases released during the thermal degradation of the hemicellulose (Prins et al., 2006a). Although, only a small portion of the cellulose degrades within the torrefaction temperature range (200-300 ${ }^{\circ} \mathrm{C}$ ), the water vapor and the acids released from the hemicellulose may also enhance the degradation of cellulose. The lignin that has more carbon than the other two polymeric constituents of biomass (Table 4) is thermally more stable and takes a larger share in the final solid product. The solid product with higher carbon content produces an energy dense product after the torrefaction.

Dry torrefaction comprises of four simple steps (Fig. 6) such as:

(a) Drying, in which only the surface (free) moisture is removed,

(b)Post - drying, in which the bound moisture as well as some of the light hydrocarbons are removed,

(c) Torrefaction - isothermal heating - in which supplied heat establishes the depolymerization, partial devolatilization, and partial carbonization reactions

(d)Cooling process (up to an ambient temperature, $\mathrm{T}_{\mathrm{a}}$ ).

The overall cycle time of the dry torrefaction process is the sum of the time taken by drying, post-drying, torrefaction and cooling process. As one can see from Figure 6, the temperature remains unchanged during the drying, and the 
torrefaction with an important distinction that the energy used during drying is highest, and that during the torrefaction is much lower. As the destructive torrefaction starts only above $200{ }^{\circ} \mathrm{C}$, the duration of the torrefaction, known as the residence time, is usually measured from the instant when the temperature of biomass exceeds that temperature (Basu, 2013).

While the wet torrefaction uses the concept of solubility of different compositions of biomass in hot and aqueous solutions, the dry torrefaction is characterized mainly by the thermal degradation of the polymeric constituents of the biomass. The degradation of the biomass during the dry torrefaction, therefore, can be explained through the drying and devolatilization process.

\section{Drying}

Drying is the major and the most energy intensive step in the torrefaction process. The drying process refers to the process of removing a surface and bound water from the raw biomass. Drying is classified as a non-reacting and a reactive process. Drying of biomass in the temperature range of 50$150{ }^{\circ} \mathrm{C}$ is known as non-reactive drying, when it mainly removes the surface water, resulting shrinkages in the product size (Tumuluru et al., 2011). The non-reactive drying is followed by the reactive drying in the temperature range of $150-200{ }^{\circ} \mathrm{C}$ at which the breakage of hydrogen, and the carbon bonds occur, emitting lipophilic extractives. This phase is characterized by a permanent structural deformation. The reactive drying substantially removes the bound water from the biomass.

\section{Devolatilization}

Devolatilization may be defined as a process of removing oxygen and volatile content of biomass. It generally occurs once the temperature of the biomass is above $200{ }^{\circ} \mathrm{C}$ at which volatiles (both gases and tar) start leaving the solid matrix of biomass (Basu and Kaushal, 2009; van de Weerdhof, 2010). It is also known as the destructive drying process, which is characterized by the devolatilization and carbonization of hemicellulose, depolymerization, devolatilization, and softening of lignin, and depolymerization and devolatilization of cellulose. However, it may be noted that the devolatilization is rarely complete during the torrefaction. The torrefied biomass always contains some volatile matters unlike the char produced from a pyrolysis process.

Table 4: Typical Elemental Analyses of Lignin, Cellulose and Hemicellulose

\begin{tabular}{|l|l|l|l|l|l|}
\hline \multirow{2}{*}{$\begin{array}{l}\text { Constituents } \\
\text { of biomass } \\
\text { cells }\end{array}$} & \multicolumn{5}{|l}{ Ultimate analysis (wt. \%, dry basis) } \\
\cline { 2 - 6 } & $\mathrm{C}$ & $\mathrm{H}$ & $\mathrm{O}$ & $\mathrm{N}$ & $\mathrm{S}$ \\
\hline Lignin & 57.70 & 4.38 & 34.00 & 0.11 & 3.22 \\
\hline Cellulose & 42.96 & 6.30 & 50.74 & 0.00 & 0.00 \\
\hline $\begin{array}{l}\text { Hemicellulose } \\
\text { (xylan) }\end{array}$ & 43.25 & 6.20 & 49.90 & 0.00 & 0.00 \\
\hline
\end{tabular}

Source: Pasangulapati et al. (2012) 


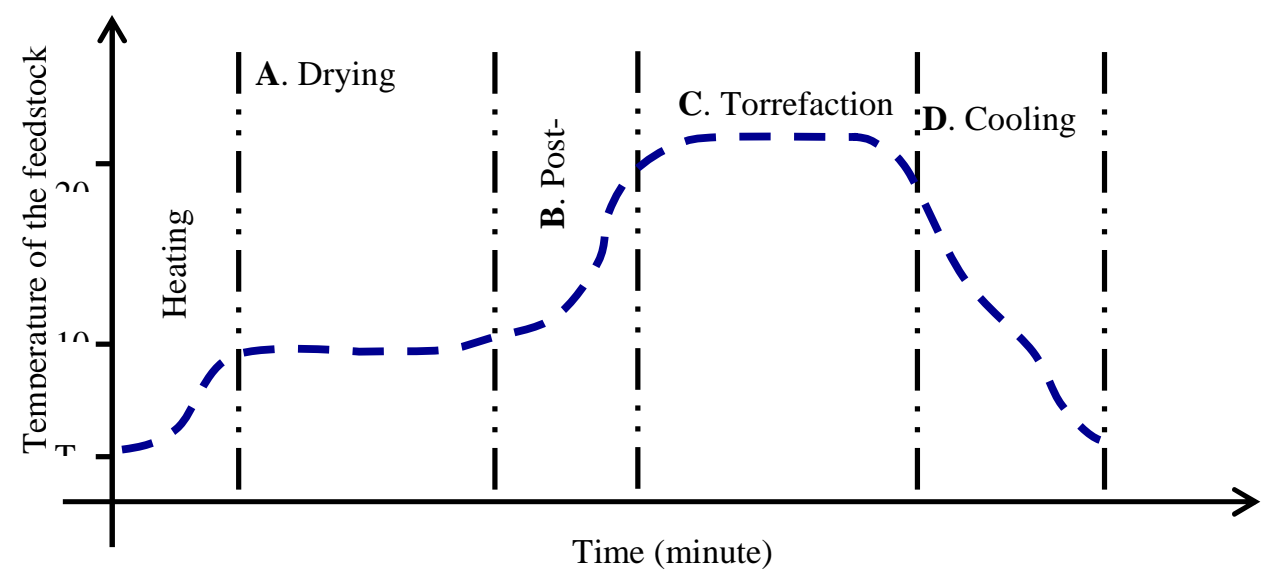

Figure 6: Stages of Torrefaction Process

\section{The Effect of Design and Operating Parameters}

\section{Temperature}

The mode of a torrefaction process may be classified as a light, mild, and severe torrefaction based on the torrefaction temperature range around $230^{\circ} \mathrm{C}, 260^{\circ} \mathrm{C}$, and $290^{\circ} \mathrm{C}$, respectively (Chen and Kuo, 2010). The temperature shows a dominant influence on the product quality of torrefaction. Solid yield of torrefaction product depends on the temperature. For instance, in one case the solid yield decreased from $94 \%$ to $56 \%$ when the torrefaction temperature increased from $220{ }^{\circ} \mathrm{C}$ to $275^{\circ} \mathrm{C}$ (Felfli et al., 2005). On the other hand, Acharya (2013) in his study of the torrefaction of Oats, reported a decrease in the energy yield but an increase in the energy density when the temperature of the torrefaction increased from $210{ }^{\circ} \mathrm{C}$ to $300{ }^{\circ} \mathrm{C}$. The mass loss or solid yield at different torrefaction temperatures can be explained mainly through the impact of the temperature on (i) polymeric compositions, and (ii) devolatilization rate.

The polymeric composition of the lingocellulosic biomass, to some extent influences the nature of the torrefied products. Table 5 presents the temperature ranges over which the thermal degradation of the hemicellulose, cellulose, and the lignin takes place during the pyrolysis process. It indicates that the lignin decomposes over a wider temperature range than the other two components. The stability of the lignin is due to the thermal stability of its different functional groups containing oxygen (Brebu and Vasile, 2009). On the other hand, hemicellulose is highly sensitive in the narrow temperature range of torrefaction. The mass loss during the torrefaction therefore, it depends highly on the devolatilization of hemicellulose. The hemicellulose shows significant effects in the initiation and propagation of different pyrolysis reactions (Rousset et al., 2011). The composition of the hemicellulose also affects the degradation rate of the biomass. For example, biomass with higher xylan in hemicellulose is more temperature sensitive than the one with a mannan based hemicellulose (Basu, 2013). The celluloss are relatively stable to the temperature than the hemicellulose, because of the crystalline structured of the cellulosic fibrils. Breakage of these crystalline fibrils, which affects glucosidic bonds between glucose monomers, and inter and intra-molecular hydrogen bonds at a higher torrefaction temperature, reduces the strength of solid products (Emsley and Stevens, 1994). Table 6 presents typical mass loss percentages of the hemicellulose, cellulose and the lignin at different torrefaction temperatures.

The devolatilization rate is defined as the rate of mass loss during the thermal 
degradation of the biomass and will be more at a high temperature. A higher heating rate of biomass at a higher operating temperature usually produces more volatile gases during the pyrolysis process, and increases the devolatilization rate. This reduces the solid product yield from the process. Figure 7 shows the effect of the temperature in the product distributions during the process of torrefaction of cotton stalk and wheat straw. The volatiles, which include both condensable, as well as non-condensable product, increased at a higher temperature torrefaction. In addition to this, the higher heating rate also affects the morphological structure of the solid product. More round pores are formed during the pyrolysis when the temperature increased from 600 ${ }^{\circ} \mathrm{C}$ to $800{ }^{\circ} \mathrm{C}$ (Guerrero et al., 2008). This establishes a larger internal cavity and more open structures.

\section{The Residence Time}

The residence time of the feedstock in the reactor is an important parameter for designing reactors. Compared to many other thermo-chemical conversion processes like combustion, gasification or pyrolysis, the reaction time for torrefaction is much longer. It is nearly an order of magnitude longer than that for other processes. Such a long reaction time requires the biomass feed to reside within the reactor for a very long time. This naturally increases the volume requirement of the reactor for a given output. The residence time has thus a greater impact on the reactor size. For example, the length and the rotational speed of the screw in a screw type reactor, and the belt speed in the conveyer belt reactor are mainly determined by the required residence time (Koppejan et al., 2012). The residence time also determines the solid space velocity and the reactor height of a moving bed torrefier.

Although, the net effect of the residence time is not as prominent as that of the temperature, the residence time influences the torrefied product at longer residence time. The solid mass loss increases with residence time, resulting in a lower solid product yield (Chen et al., 2011, Acharya et al., 2012). This is due to an increase in the extent of devolatilization (Prins et al., 2006a). Condensable product contributes significantly to the solid mass loss at a higher residence time, as it increases with time as shown in Fig. 8. On the other hand, non- condensable product such as $\mathrm{CO}_{2}$ and CO reaches the peak value at a residence time of 10 minutes, and then starts declining (Bates and Ghoniem, 2012). The amount of methanol and lactic acid, which are produced during the decomposition of acetoxy- and methoxy-, groups (Tumuluru et al., 2012), increase up to 10 minutes and then remain unchanged (Bates and Ghoniem, 2012).

With an increase in the residence time, one expects an increase in the carbon content, and a decrease in the hydrogen and oxygen content of the torrefied product. For example, the carbon content of a palm kernel shell increased from $55 \%$ to $58 \%$ at a torrefaction temperature of $250{ }^{\circ} \mathrm{C}$, when the residence time was increased from 30 to 90 minutes (Felfli et al., 2005). At the same condition, the oxygen content of the product was decreased from $31 \%$ to $29 \%$. It is interesting that though the carbon content increases with the residence time, the absolute value of the carbon always decreases due to the increase in the reaction of carbon dioxide and the steam with the porous char (Prins et al., 2006a). They reported that a gradual decrease in $\mathrm{CO}_{2}$ and an increase in $\mathrm{CO}$ composition were found in the non-condensable volatiles when the residence time increased from 5 to 30 minutes. This suggests that the formation of $\mathrm{CO}$ increases in the secondary reactions occurring at a longer residence time, which increases the energy content of the volatile gas and reduces the overall torrefaction efficiency, especially if volatiles were not utilized. The quantity of $\mathrm{CO}_{2}$ and $\mathrm{CO}$ in volatile gases is significant only at higher torrefaction temperature (Deng et al., 2009). On the other hand, the relative amount of the carbon loss with that of the oxygen also increases with the rise in the residence time. For instance, Bates and Ghoniem (2012) found that the amount of carbon and oxygen losses was $11 \%$ and $40 \%$ in 15 
minutes compared to $26 \%$ and $69 \%$ in 40 minutes, resulting more carbon loss per a unit of oxygen loss (from 0.275 to 0.377 ). This suggests that the rate of de- oxygenation of biomass slows down at the higher residence time, which increases the carbon content in the volatiles.

Table 5: Temperature Range for Peak Thermal Degradation of Hemicellulose, Cellulose, and Lignin

\begin{tabular}{|l|l|l|l|}
\hline \multicolumn{2}{|l|}{ Degradation temperature range $\left({ }^{\circ} \mathrm{C}\right)$} & \multirow{2}{*}{ Source } \\
\hline Hemicellulose & Cellulose & Lignin & \\
\hline $220-315$ & $315-400$ & $160-900$ & Yang et al. (2007) \\
\hline $225-325$ & $305-375$ & $250-500$ & Shafizadeh (1985) \\
\hline $200-400$ & $275-400$ & $200-500$ & Sorum et al. (2001) \\
\hline $250-350$ & $300-430$ & $250-550$ & Raveendran et al. (1996) \\
\hline $227-327$ & $327-407$ & $127-477$ & Giudicianni et al. (2013) \\
\hline
\end{tabular}

Table 6: Weight Losses in Polymer Components with Temperatures

\begin{tabular}{|l|l|l|l|}
\hline $\begin{array}{l}\text { Torrefaction } \\
\text { temperature }\left({ }^{\circ} \mathrm{C}\right)\end{array}$ & Hemicellulose (wt \%) & Cellulose (wt \%) & Lignin (wt \%) \\
\hline 230 & 2.74 & 1.05 & 1.45 \\
\hline 260 & 37.98 & 4.43 & 3.12 \\
\hline 290 & 58.33 & 44.82 & 6.97 \\
\hline
\end{tabular}

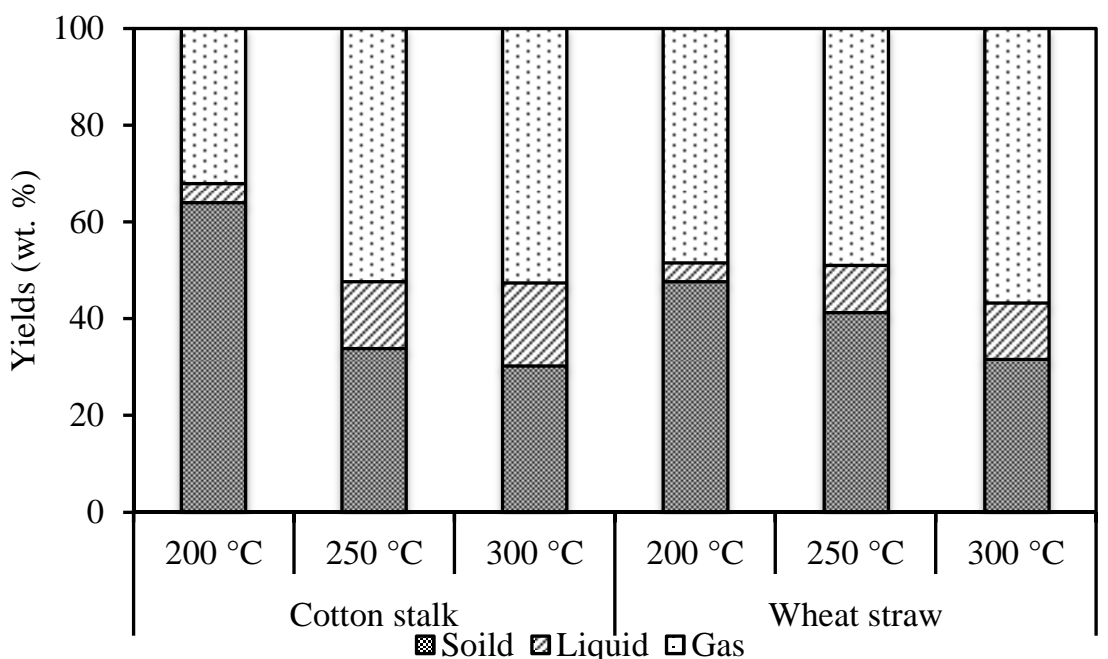

Figure 7: Effect of Torrefaction Temperature in Product Distribution of Cotton Stalk and Wheat Straw (Residence Time $=30$ Minutes)

Source: Adapted from Wang et al. (2011) 


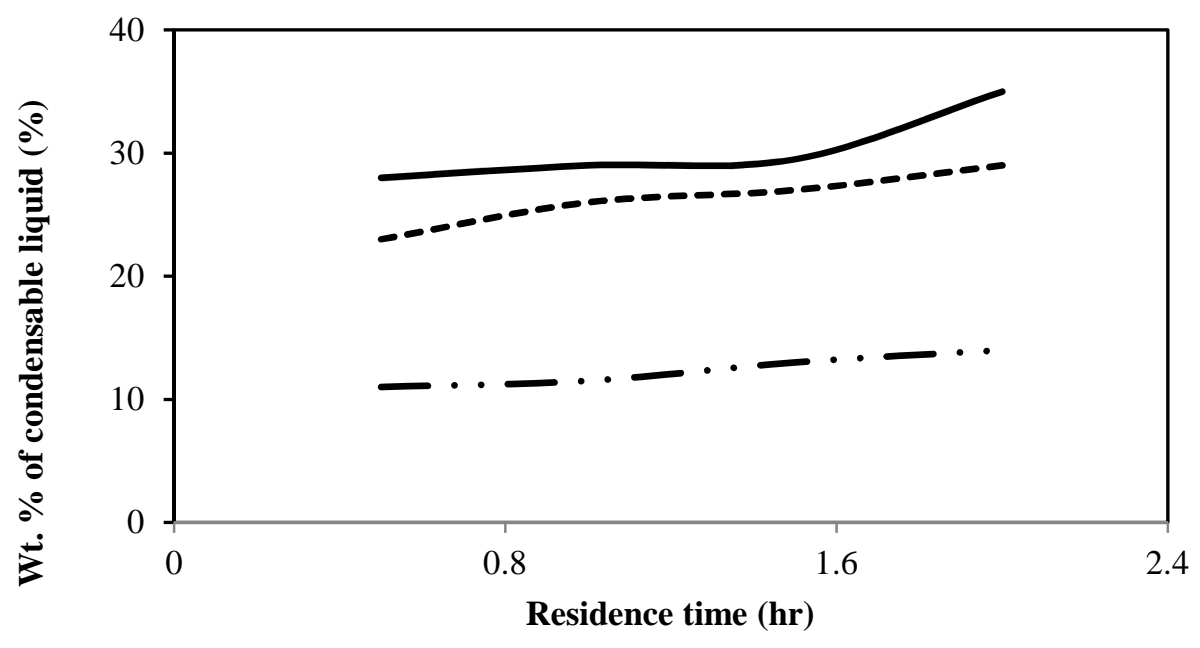

$\longrightarrow 220---250 \longrightarrow 280$

Figure 8: Variations in Condensable Liquid with Torrefaction Temperature Source: Adapted from Chen et al. (2011)

\section{Oxygen Concentration}

The presence of oxygen in the torrefaction media increases the extent of the combustion reactions, which converts a carbon into a flue gas instead of leaving it in a solid form. Additionally, the combustion in the reactor could increase the temperature of the product endangering the safety of the unit. Therefore, oxygen is not desirable for the safe and efficient operation of the torrefaction process. So, torrefaction would require either indirect heating or a continuous supply of hot inert gas. The latter option is not economically feasible. To minimize the energy cost, in a commercial torrefaction unit, the flue gas could be used as both a heat source and a working media. But the flue gas form a combustion process which is always associated with some free oxygen. To get more insight into the effect of this oxygen on the torrefaction, a brief review of this is presented below.

The solid product yield of torrefaction decreases when the oxygen is present in the working media. Uemura et al. (2013) and Basu et al. (2013) noted appreciable effect of oxygen on solid yield at $250{ }^{\circ} \mathrm{C}$. The extent of this depends on the torrefaction temperature, but. Rousset et al. (2012) observed only negligible changes in the torrefied solid yield at around 250 ${ }^{\circ} \mathrm{C}$.

The presence of the oxygen in the working media increases the devolatilization reactions that have the higher ability to remove the oxygen from the sample compared to that of the nitrogen media. But Rousset et al. (2012) observed only a slight change in the values of $\mathrm{O} / \mathrm{C}$ and $\mathrm{H} / \mathrm{C}$ for eucalyptus wood under the air and the nitrogen media. The $\mathrm{O} / \mathrm{C}$ and $\mathrm{H} / \mathrm{C}$ ratios decreased with the rise in the oxygen concentration.

However, some studies (Basu et al., 2013; Rousset et al., 2012; Uemura et al., 2013; Wang et al., 2012) found that oxidative media shows only a minor effects on the heating value of the solid product. Tumuluru et al. (2011) noted some increase in the heating value of willow, the red canary grass and the wheat straw with a rise in the torrefaction temperature in an inert medium. Lu et al. (2012) noted that the heating value of the oil palm fiber torrefied in the nitrogen is higher than that in the air, which agrees with the observation of Tumuluru, but that did not happen for eucalyptus, where oxygen had minor effect on HHV except above $300{ }^{\circ} \mathrm{C}$. The other differences between these two 
biomass are that HHV of the air-torrefied oil palm fiber decreased steadily with the torrefaction temperature, while the torrefaction temperature had minor effect on HHV of eucalyptus torrefied in air. The data point being limited are not certain if this can be taken as an effect of the type of biomass.

Lu et al. (2012) made a comparative study of the torrefaction using the eucalyptus wood and the oil palm fiber in the nitrogen and air media. Both, solid and energy yield were less in the air media than that in the nitrogen for both oil palm fiber and eucalyptus wood, but the yields decreased with the torrefaction temperature for both types. Lu et al. (2012) used a new parameter (energy-mass co-benefit index to assess the effectiveness of a torrefaction process. Using this index, they concluded that the use of the air is suitable for the eucalyptus wood but not for the oil palm fiber.

The torrefaction under the oxidative media, however, reduces to the torrefaction process time required for a given mass loss (Wang et al., 2012). Table 7 presents the torrefaction time required for a torrefaction process at $280{ }^{\circ} \mathrm{C}$ with different oxygen concentration in the working media. In addition to the time saving, Wang et al. (2012) also proved that the flue gas with the oxygen could be used as a working media without any significant changes in the torrefaction process and the product. This reduction in the torrefaction could have much practical significance, as it might reduce the size of the torrefaction reactor, and therefore the capital investment required.

\section{The Particle Size}

The heat source is required to preheat, dry, and devolatilize the biomass for the torrefaction process. The amount of the heat required depends on the size, shape, and biomass properties. These parameters affect both the convective and the conductive heat transfer rate from the reactor to the biomass and within the biomass, respectively. A larger piece of biomass will have less surface area per unit mass, reducing the convective heat transfer rate. The larger particle may also have nonuniform heat distribution within the biomass due to the anisotropic and heterogeneous properties of the biomass. In addition to this, the larger particle may face difficulties with the volatile diffusion through it because of the high mass transfer resistance. Thus, the quality of the torrefaction process may not be identical for all particle sizes. In this context, the effect of the particle size may be analyzed by estimating the Biot and the Pyrolysis number of the process.

The Mass loss due to the torrefaction in the smaller particles (size varies from 0.23 to $0.81 \mathrm{~mm}$ ) is higher than that in the larger particles (Peng et al., 2012) due to both, the lower resistances to the diffusion of volatiles and the higher heat transfer rate in small particles. For example, Medic et al. (2011) noted a higher mass loss in the ground corn Stover compared to that of the whole Stover. Even in a bubbling bed reactor that is characterized by a high heat transfer rate, Kokko et al. (2012) found a higher mass loss in the smaller particle compared to that of the bigger particle. A finer particle size also increases the mass losses in the microwave-assisted torrefaction process (Wang et al., 2012a). They observed the mass reduction ratios of $65 \%, 69 \%$, and $72 \%$, when the particle sizes were in the range of $0.149-0.297 \mathrm{~mm}$, 0.149-0.074 $\mathrm{mm}$, and $<0.074 \mathrm{~mm}$, respectively. The greater intra-particle effect and the heat transfer area in the fine particles causes a higher reaction temperature, enhancing the devolatilization reactions. The effect of the particle size on the mass and energy yields in torrefaction at different temperature and time is shown in Fig. 9. It shows a small but consistent increase in the mass and energy yields.

On the other hand, a study on a large cylindrical particle (size varies from 5 to 25 $\mathrm{mm}$ diameter with a constant length of 65 $\mathrm{mm}$ ) observed a lower solid product yield when the diameter of the particle size increased (Basu et al., 2013a). They also found that in the large particle size the core temperature of the particle was greater 
than that of the furnace it was in, indicating the exothermicity of the torrefaction process. This is due to the higher heat transfer resistance in the large particles compared with that of the smaller particles.

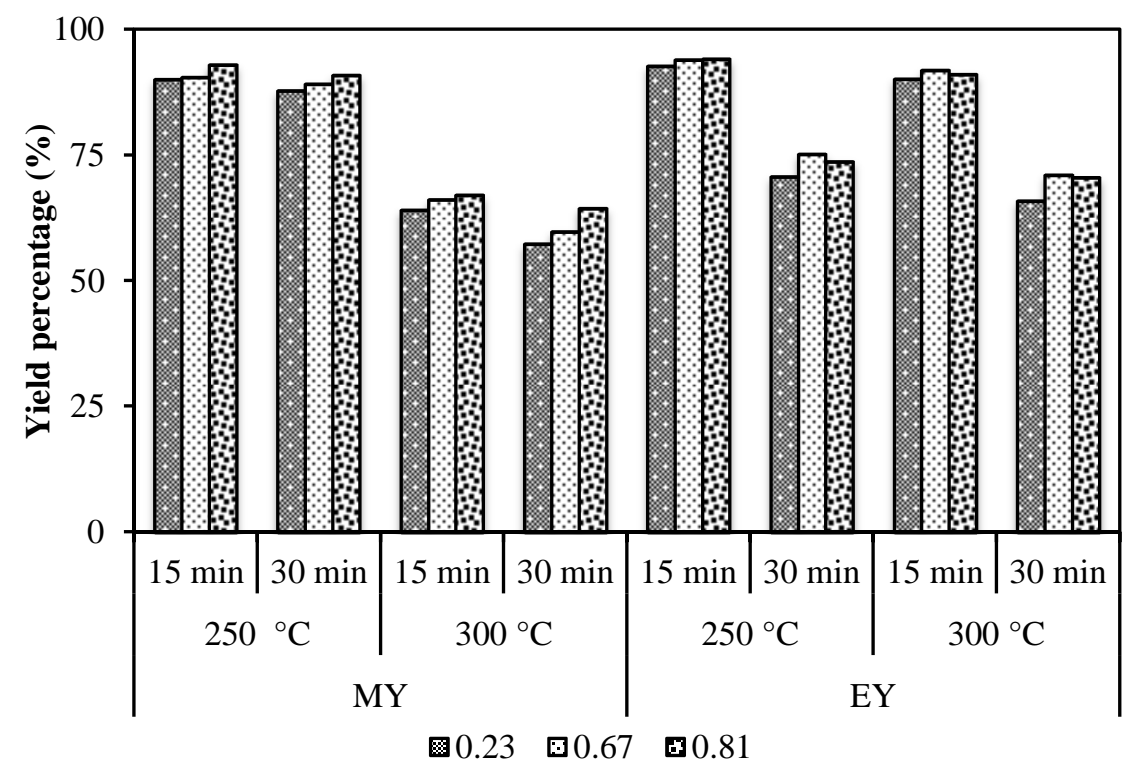

Figure 9: Particle Size (mm) Effect on Mass and Energy Yield at Different Temperature and Time

Source: Adapted from Peng et al. (2012)

Table 7: Reduction of Process Time for Similar Output in Torrefaction Process under Oxidative Environment at $280{ }^{\circ} \mathrm{C}$

\begin{tabular}{|l|c|c|c|c|c|}
\hline & \multicolumn{5}{|c|}{ Oxygen concentration in working media (vol. \%) } \\
\cline { 2 - 6 } & 0 & 3 & 6 & 10 & 21 \\
\hline $\begin{array}{l}\text { Time for 70\% } \\
\text { solid product yield } \\
\text { (sec) }\end{array}$ & 2640 & 1690 & 1540 & 1260 & 840 \\
\hline $\begin{array}{l}\text { Solid product } \\
\text { yield at 2640 sec } \\
(\%)\end{array}$ & 70 & 61.4 & 56.8 & 48.6 & 42.4 \\
\hline
\end{tabular}

Source: Adapted from Wang et al. (2012)

\section{The Reactor Type}

The torrefier - based on the mode of heat transfer - is broadly classified into two types: (i) direct heating and, (ii) indirect heating (Dhungana et al., 2012a). the most common reactors such as moving bed, augur, entrained bed, microwave, fluidized bed, hydrothermal, and rotary drum reactors fall within one of these two categories. The movement of biomass, the working media, and the heat transfer mechanism are the most important distinguishing features of the reactors. These features determine the nature of the torrefied products, as well as the total torrefaction time. For example, the rotational speed, length of the drum, and the tilt of the drum characterizes the rotary drum torrefier (Koppejan et al., 2012). The rotational speed determines the heat transfer rate, whereas the drum length affects the residence time. In Torbed (fluidized bed) reactor, where the heat carrier fluid move at a relatively high velocity, is characterized by its intense heat 
transfer rate. This reactor can produce the torrefied biomass at a very shorter residence time (around $80 \mathrm{sec}$ ), while using fine particles (Koppejan et al., 2012). The major advantages and disadvantages on different types of reactors are presented in Table 8.

A comparative study between different reactors - keeping all other conditions the same is presented in Dhungana et al. (2012a) in which they observed that rotary drum reactor has lower solid product yield compared to that for convective reactor and fluidized bed reactor. This could be due to the differences in the gas to the particle heat transfer in the specific reactor type. In the rotary drum reactor, the primary heat transfer from the reactor to the particle is through the thermal conduction between the reactor wall and particles. The possibility of a high heat transfer rate to the particle due to a continuous tumbling action of the particle with the rotational movement of the reactor, may be one of the reasons behind the lower solid product yield in rotary drum reactor. Additionally, the high heat transfer to surface of the large particles could give a higher temperature in the particle core. This may also increase the mass loss.

The microwave torrefaction uses the microwave irradiation as a heat source, which is characterized by its fast internal and uniform heating properties (Ren et al., 2012). The microwave heating can be achieved by two mechanisms viz. the rotation of dipoles, and the migration of ions (Huang et al., 2012). The microwave torrefaction requires moisture content less than $10 \%$ but it is not necessary the particle to be small (Wang et al., 2012a). the characteristics of the microwave torrefaction depend on the type of materials and their ability in absorbing the microwave radiation. Since the microwave torrefaction is powered by the microwave irradiation, torrefaction temperature; and the biomass-heating rate depend highly on the power of the microwave. This alters both physio-chemical properties of torrefied product, especially in the morphological structure. A higher microwave power could achieve the torrefaction temperature of biomass in the reactor in a very short period of time, and thus significantly reduce the processing time (Huang et al., 2012). However, in the large particles there may be significant temperature gradient in the particle resulting in a non-uniform torrefaction (Dhungana, 2011). Huang et al. (2012) did not notice this effect as they used small particles of average diameter $0.297 \mathrm{~mm}$.

Figure 10 shows how the mass and energy yields decrease with the increase in the microwave power. A significant loss in the masses of rice husk and Pennisetum at a higher microwave power is due to the higher torrefaction temperature obtained at 25 minutes residence time. The temperature of biomass in the reactor rose well above $300{ }^{\circ} \mathrm{C}$ at 25 minutes when the microwave power was in the range 250350 W. Huang et al. (2012) also showed that the biomass temperature increased with both, the time and microwave power. At higher microwave power, the torrefaction temperature exceeded $300{ }^{\circ} \mathrm{C}$ within 10 minutes and such fast heating rate is known to reduce solid yield (Basu, 2010). Thus, being an energy efficient heating method and a high potential to release volatiles in a short time interval, the microwave torrefaction has a higher possibility of enhancing the porosity of products, and improves the combustion properties of the biomass. The information on the morphological changes in the biomass with the microwave power, and the combustion and gasification characteristics of the solid product under the microwave torrefaction are still unavailable in literatures. 
Table 8: Advantages and Limitations of Different Types of Torrefaction Reactors

\begin{tabular}{|c|c|c|}
\hline Reactor type & Advantages & Limitations \\
\hline Rotary drum & $\begin{array}{l}\text { - Proven relatively } \\
\text { simple equipment } \\
\text { - Low pressure drop } \\
\text { - Possibility of both } \\
\text { direct and indirect heating }\end{array}$ & $\begin{array}{l}\text { - Lower heat transfer (specially in } \\
\text { indirect heating) } \\
\text { - } \quad \text { Difficult to measure and control } \\
\text { temperature } \\
\text { - } \quad \text { Less plug flow compared with } \\
\text { other reactors } \\
\text { - } \quad \text { Bigger system size } \\
\text { - } \quad \text { Necessary proper drum sealing } \\
\text { - } \quad \text { Difficult in scaling up the system }\end{array}$ \\
\hline Moving bed & $\begin{array}{l}\text { - Simple reactor and its } \\
\text { construction } \\
\text { - Very good heat transfer } \\
\text { - } \quad \text { High bed density }\end{array}$ & $\begin{array}{l}\text { - Significant pressure drop } \\
\text { - Difficult to control temperature }\end{array}$ \\
\hline Screw type & $\begin{array}{l}\text { - Possibility for plug flow } \\
\text { - Mature technology for } \\
\text { torrefaction }\end{array}$ & $\begin{array}{l}\text { - } \text { Indirect heating only } \\
\text { - } \text { Higher possibility of hot spots } \\
\text { - } \quad \text { Lower heat transfer rate } \\
\text { - } \quad \text { Scale up problem } \\
\text { - } \quad \text { Require shaft sealing }\end{array}$ \\
\hline $\begin{array}{l}\text { Multiple heart } \\
\text { furnace }\end{array}$ & $\begin{array}{l}\text { - Proven equipment } \\
\text { design } \\
\text { - Higher possibility of } \\
\text { scale up } \\
\text { - Close to plug flow } \\
\text { - Good temperature and } \\
\text { residence time control } \\
\text { - Possibility of adding } \\
\text { fines }\end{array}$ & $\begin{array}{l}\text { - } \quad \text { Lower heat transfer rate } \\
\text { compared with other direct reactors } \\
\text { - } \quad \text { Limited volumetric capacity } \\
\text { - Relatively larger reactors } \\
\text { - } \quad \text { Require shaft sealing }\end{array}$ \\
\hline Fluidized bed & $\begin{array}{l}\text { - Excellent heat transfer } \\
\text { rate } \\
\text { - Easily scalable }\end{array}$ & $\begin{array}{l}\text { - Require smaller particle size } \\
\text { - Necessary to have additional gas } \\
\text { equipment to supply fluidizing fluids } \\
\text { - Possibility of attrition (fines } \\
\text { formation) } \\
\text { - Difficult to get plug flow }\end{array}$ \\
\hline
\end{tabular}

Source: Adapted from Bi (2012) 


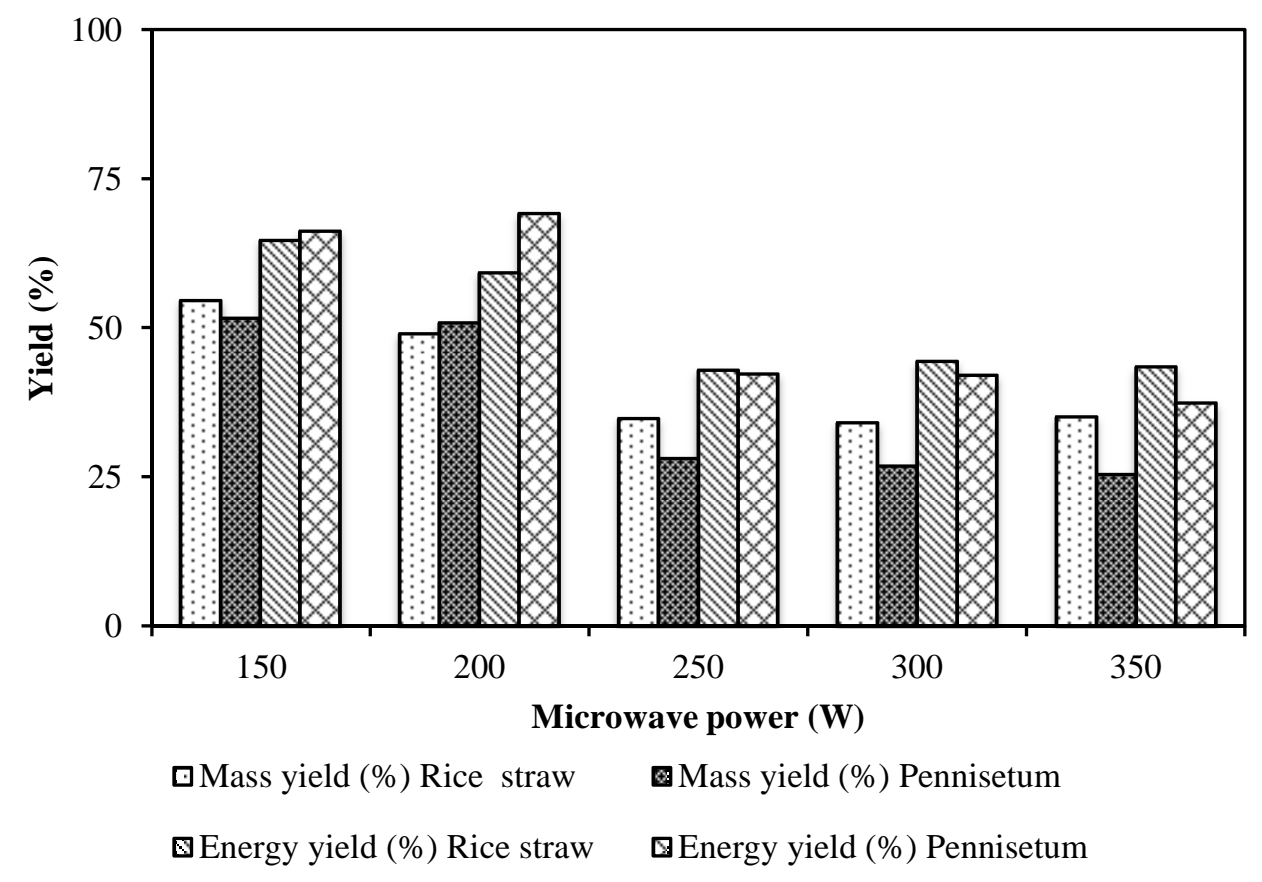

Figure 10: Effect of Microwave Power in Solid Product (Mass) and Energy Yields of Rice Straw and Pennisetum under the Microwave Torrefaction at Residence Time of 25 Minutes

Source: Adapted from Huang et al. (2012)

\section{The Effect of the Torrefaction on the Biomass Properties}

The torrefaction process has significant effects on the different properties of the biomass such as the proximate analyses, ultimate analyses, solid residue, heating values, hydrophobicity, grindability, density and the volume of the sample. In the following sub-sections, the changes in these properties of the biomass due to the torrefaction process are discussed.

\section{Proximate and Ultimate Analysis}

The torrefaction process converts the complex polymers of biomass into the smaller monomers, and then the smaller monomer into condensable and noncondensable volatile gases. This transformation alters both, the proximate and ultimate analyses of the biomass. The Torrefaction drives away the volatile matter, as well as fixed carbon from a biomass due to the decomposition and the devolatilization reactions. Although, the absolute amount of the fixed carbon decreases after the torrefaction process, the fraction of the fixed carbon in the torrefied biomass increases. However, the fraction of ash, the inert and noncombustible material in biomass increases even more, because none of it is driven away during the torrefaction.

The decrease in the volatiles along with the chemical transformation of the remaining polymeric components produces a brittle carbonaceous coal like solid torrefied products. The torrefied product would, therefore, have a proximate and ultimate composition different from that of the parent biomass. The change in the proximate composition of the torrefied biomass is influenced by both temperature and residence time of torrefaction. The increase in time and temperature reduces the volatile content of biomass (Arias et al., 2008). The typical proximate analyses of the torrefied Pine chips, Laucaena, and Eucalyptus wood at different torrefaction temperature is shown in Fig. 11. 
Moisture loss, which is one of the components in condensable products, makes a major contribution to the total mass reduction. The typical condensable products including tars were observed more than $50 \%$ of the total mass loss at all operating conditions (Chen et al., 2011). Longer residence time releases more volatiles gases and leads to the evolution of a secondary volatiles gases, which has relatively a higher energy value than the first stage volatiles. For instance, Bates and Ghoniem (2013) found that the first stage volatile in the two-step torrefaction kinetics has heating the value of only 4.4 $\mathrm{MJ} / \mathrm{kg}$ compared to $16 \mathrm{MJ} / \mathrm{kg}$ in the second stage volatiles.

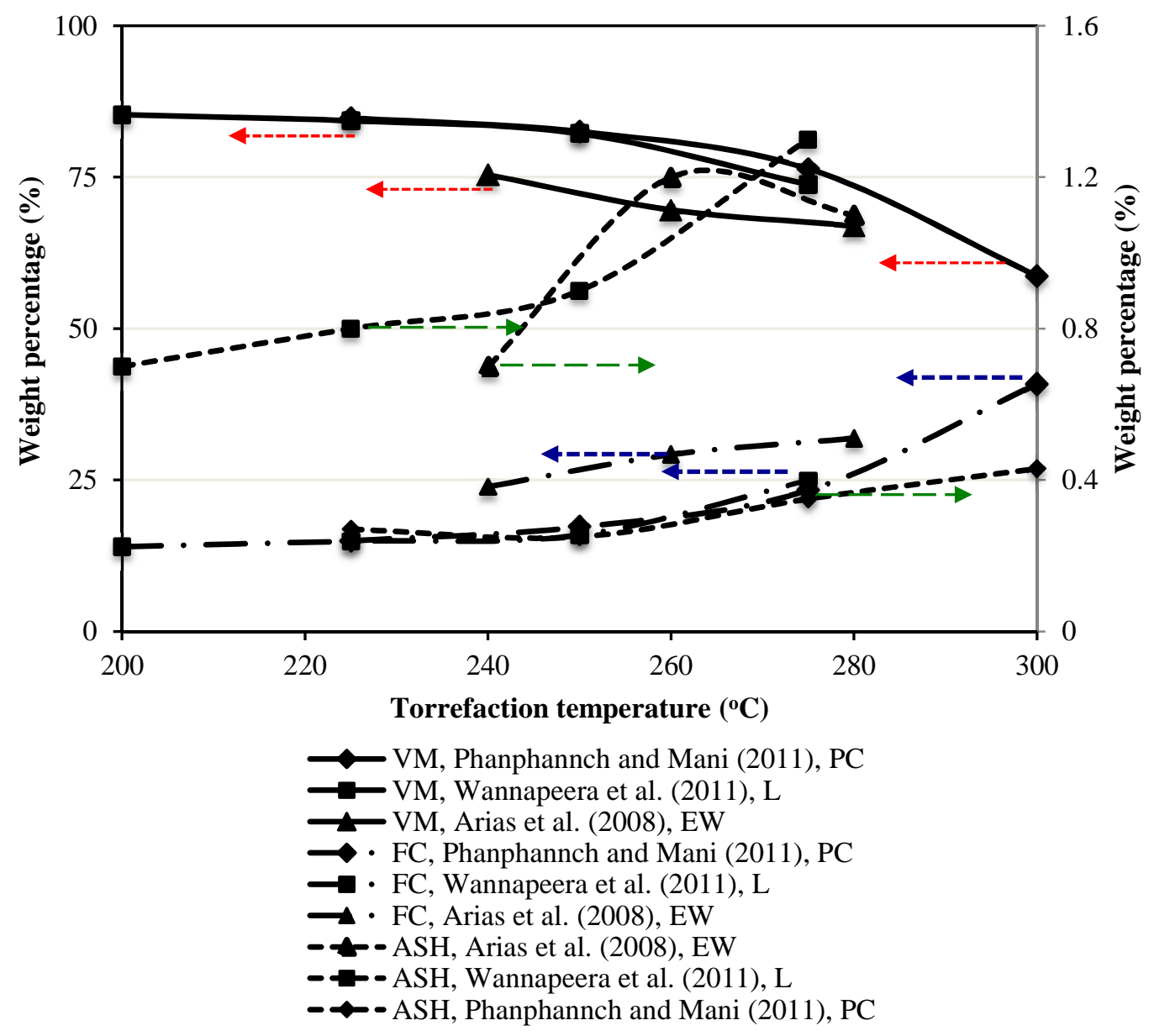

Figure 11: Volatile Matter (VM), ash Content (ASH), and Fixed Carbon (FC) Content of Biomass in wt. \% Dry Basis with Torrefaction Temperature at a Residence Time of 30 Min (PC=Pine Chips, L=Laucaena, and EW=Eucalyptus Wood)

The carbon usually contributes $60-85 \%$ of the total mass of the coal composition, whereas the oxygen content ranges from 5$20 \%$ (Prins et al., 2007). Biomass on the other hand contains much lower carbon (50\%) but much higher oxygen (45\%). This indicates that $0 / \mathrm{C}$ ratio of biomass is very high compared with that of coal. This significantly reduces the energy density of biomass. Therefore, torrefaction $-a$ technology capable of reducing $0 / C$ in biomass - has a greater impact on the energy density of biomass.

Arias et al. (2008) found about 26\% reduction in the oxygen and $24 \%$ increment of carbon content in the eucalyptus wood after it is torrefied at 280 ${ }^{\circ} \mathrm{C}$ for 3 hours. These changes are in contrast with that of Chen et al. (2011) who 
observed around $45 \%$ less oxygen and $44 \%$ more carbon content in the Lauan block after it is torrefied at $280{ }^{\circ} \mathrm{C}$ in 2 hours. This indicates that the longer residence time alone does not necessarily have a major effect on the change with carbon and oxygen content in a biomass. Other than operating conditions, changes in the ultimate analyses also depend on the particle size, type of materials, and the method of torrefaction. The rate of increasing carbon content is higher in severe torrefaction condition. For instance, the carbon increment rate was found 0.88 wt. \% of dry ash free carbon per hour at $220{ }^{\circ} \mathrm{C}$, while it was $1.55 \%$ and $3.66 \%$ per hour at $250{ }^{\circ} \mathrm{C}$ and $280{ }^{\circ} \mathrm{C}$, respectively. While the carbon content was increased in the torrefied products, both oxygen and hydrogen were decreased (Bridgeman, et al., 2008; Felfli et al., 2005). A typical chemical composition of briquettes after torrefaction is shown in Fig. 12. The one easily notes here that while the carbon percentage increases, the hydrogen decreases with both temperature and residence time.

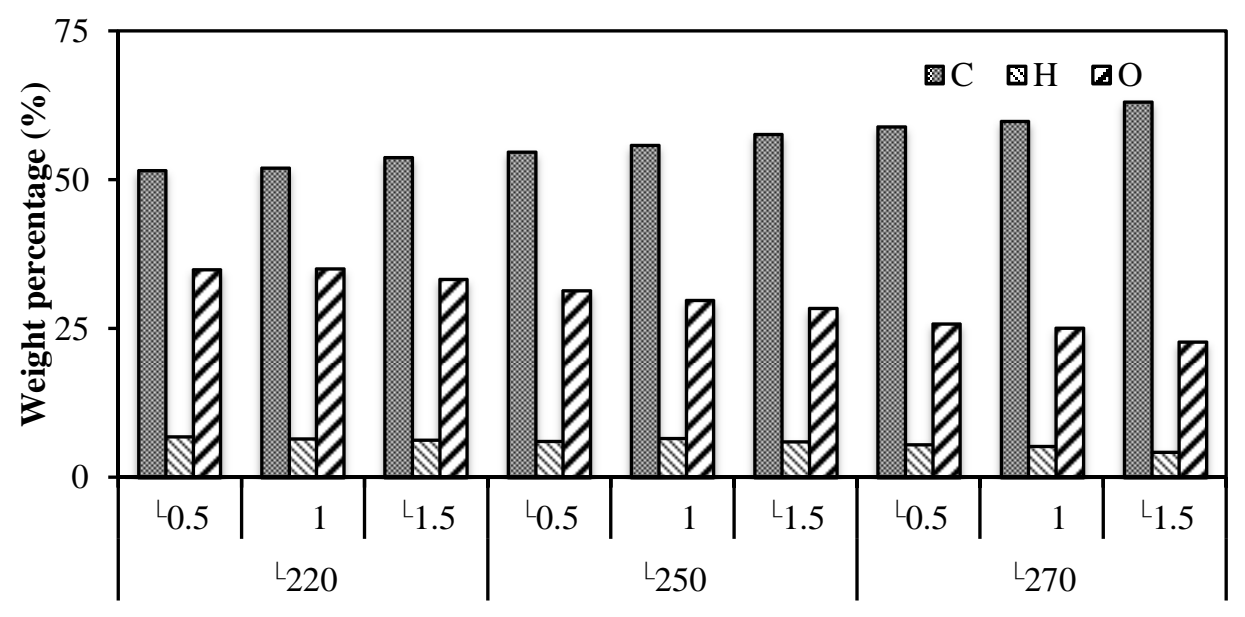

Residence time (hrs) and torrefaction temperature $\left({ }^{\circ} \mathrm{C}\right)$

Figure 12: Chemical Composition (in Dry and Ash Free Basis) of Briquette at Different Torrefaction Temperature and Residence Time Source: Adapted from Felfli et al. (2005)

\section{Solid Product and Energy Yield}

The solid product yield and the energy yield are important quantitative and qualitative measures of a torrefaction process. The solid product yield is defined as a ratio of the final mass of the solid torrefied product to the initial mass, whereas the energy yield is a ratio of the final energy in the solid product to the initial energy content of the raw biomass. Both the solid product and the energy yields are expressed in dry basis or in dry and ash free (DAF) basis.

\section{Solid Product Yield}

The torrefaction process yields solid, condensable (liquid), and non-condensable products (light volatiles) among which solid is the desired product (Wang et al., 2011). The fractions of the individual products vary with operating conditions. The solid product is made of original sugar structures, modified sugar structures, newly formed polymeric structures, and ash content, whereas the condensable products comprise mainly of water, organics (sugars, poly-sugars, acids, alcohols, furans, and ketones), and lipids (tarpenes, phenols, waxes, fatty acids, and tannins). The non-condensable product is a mixture of gases like $\mathrm{CO}_{2}, \mathrm{CO}, \mathrm{CH}_{4}, \mathrm{C}_{\mathrm{x}} \mathrm{H}_{\mathrm{y}}$, toluene, and benzene (Bergman, et al., 2005a; Yang et al., 2007). The condensable product contains water vapor and heavy tars. This liquid fraction of the torrefaction product depends on the process 
temperature and time. Figure 8 shows how the fraction of the condensable product changed with the residence time and temperature in a typical case. This effect might be due to the decomposition of the molecules with hydroxyl groups, releasing more water vapor. For instance, an increase in water vapor from $7.6 \%$ to $17.8 \%$ was reported in Wannapeera et al. (2011) when the torrefaction temperature increased from $200^{\circ} \mathrm{C}$ to $275^{\circ} \mathrm{C}$.

The fraction of solid product yields varies widely from $50 \%$ to $97 \%$ (Felfli et al., 2005) depending on the temperature and residence time. The solid yield also depends on the type of the biomass materials (Prins et al., 2006a). Figure 13 shows how the solid product yield depends on the hemicellulose content of the biomass. It reveals that the lignocellulosic biomass with higher hemicellulose composition has lower solid product yield. For instance, the willow, which has the least hemicellulose content of $14 \%$ compared to $30 \%$ with that of reed canary grass and $31 \%$ with that of wheat straw, shows the highest solid product yield (Bridgeman et al., 2008). The high-pressure like a pressurized torrefaction system could increase the solid product yield. This could be due to the possible trapping of the heavy volatiles within the pores of biomass. However, the trapped heavy volatiles may devolatilize into light volatiles that easily escape from the biomass when the torrefaction temperature, and the residence time are increased. For instance, Wannapeera and Worsauwannarak (2012) found an increase in the solid product yield from $88.2 \%$ to $89.9 \%$ at $200{ }^{\circ} \mathrm{C}$, when the reactor pressure increased from the atmospheric condition $(0.1 \mathrm{MPa})$ to $4 \mathrm{MPa}$. But they also observed a gradual decrease in the solid product yield with a rise in the temperature from $225^{\circ} \mathrm{C}$ to $250{ }^{\circ} \mathrm{C}$.

\section{Energy Yield}

The losses in the quantitative measure (solid product yield) do not show any importance while selecting an operating condition of the torrefaction process. The higher mass loss could be desirable if the qualitative measure (energy yield) is within an acceptable range. Therefore, the quality of the solid product, which is measured in term of the energy density of torrefied biomass, is of a greater importance.

The heating value of the torrefied biomass increases because it has more $\mathrm{C}-\mathrm{C}$ and $\mathrm{C}-\mathrm{H}$ bonds with the aromatic molecules (Ben and Ragauskas, 2012) with an ability to release more energy than $\mathrm{O}-\mathrm{H}$ and $\mathrm{C}-\mathrm{O}$ bonds in the raw biomass. The reduction in the hydrogen and oxygen reduces the $0 / C$ and the $\mathrm{H} / \mathrm{C}$ ratios of biomass. This moves the torrefied biomass towards the coal side in the Van Krevelen diagram (Fig. 14). The higher torrefaction temperature and residence time decrease $\mathrm{O} / \mathrm{C}$ and $\mathrm{H} / \mathrm{C}$ ratios and move the torrefied product close to that of the coal. This suggests that the formation of $\mathrm{CO}_{2}$ and $\mathrm{H}_{2} \mathrm{O}$ increases with the temperature and residence time due to the release of oxygen from biomass. For example at different residence time and temperature, the $\mathrm{O} / \mathrm{C}$ of the deciduous wood decreases from 0.70 to 0.52 (Prins et al., 2006). The biomass with higher hemicellulose, which has the highest oxygen compositions, is more likely to produce an energy dense product. This indicates that the energy density of the solid product also depends on the type of the biomass. But the question is how the energy density varies with the type of biomass. Higher the lignin content, the more energy will be extractable from the biomass. Thus, the torrefied solid product from a biomass with higher lignin content becomes more energy dense fuel compared to others with lower lignin content. Thus, a complete elimination of both cellulose and hemicellulose contents of the wood produces a product that could have energy density similar with that of the coal. Ben and Ragauskas (2012) noted that the energy density of the loblolly pine increased to $32.34 \mathrm{MJ} / \mathrm{kg}$ when the torrefaction was carried out at $300{ }^{\circ} \mathrm{C}$ for 4 hours. 


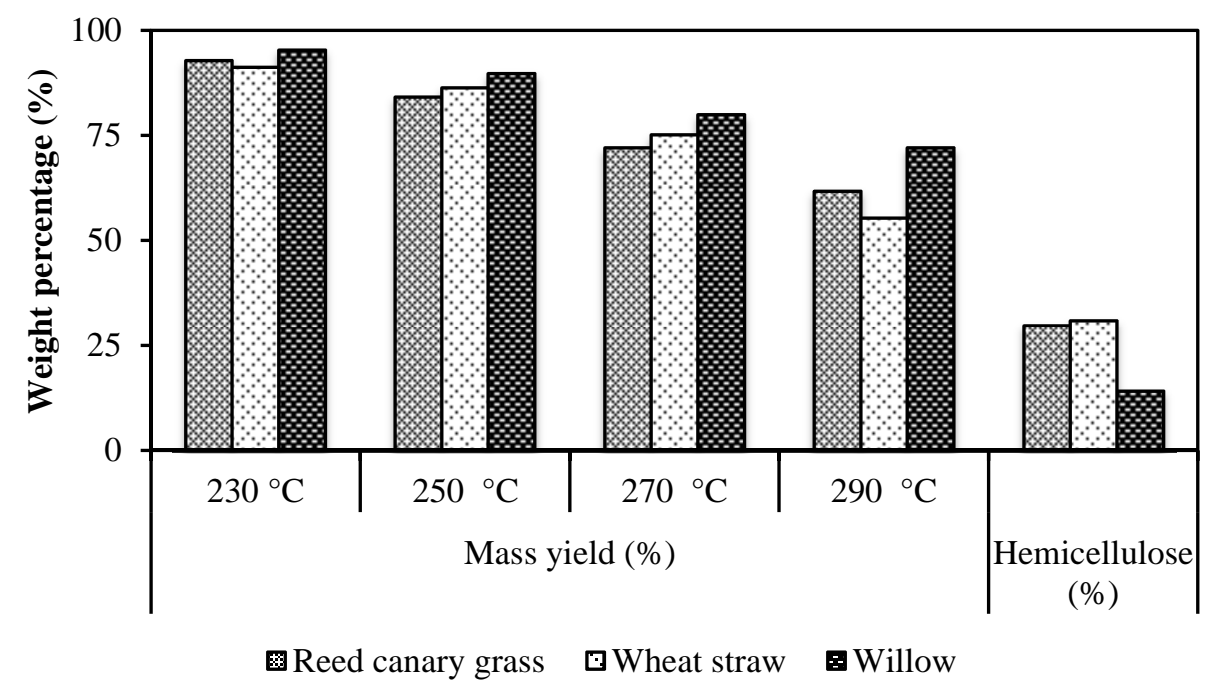

Figure 13: Energy Yield and Solid Product Yield (Mass Yield) in Dry and Ash Free Basis from the Torrefaction of Reed Canary Grass, Willow and Wheat Straw (Residence Time of 30 Minutes) Showing Effect of Temperature and Biomass Type

Source: Adapted from Bridgeman et al. (2008)

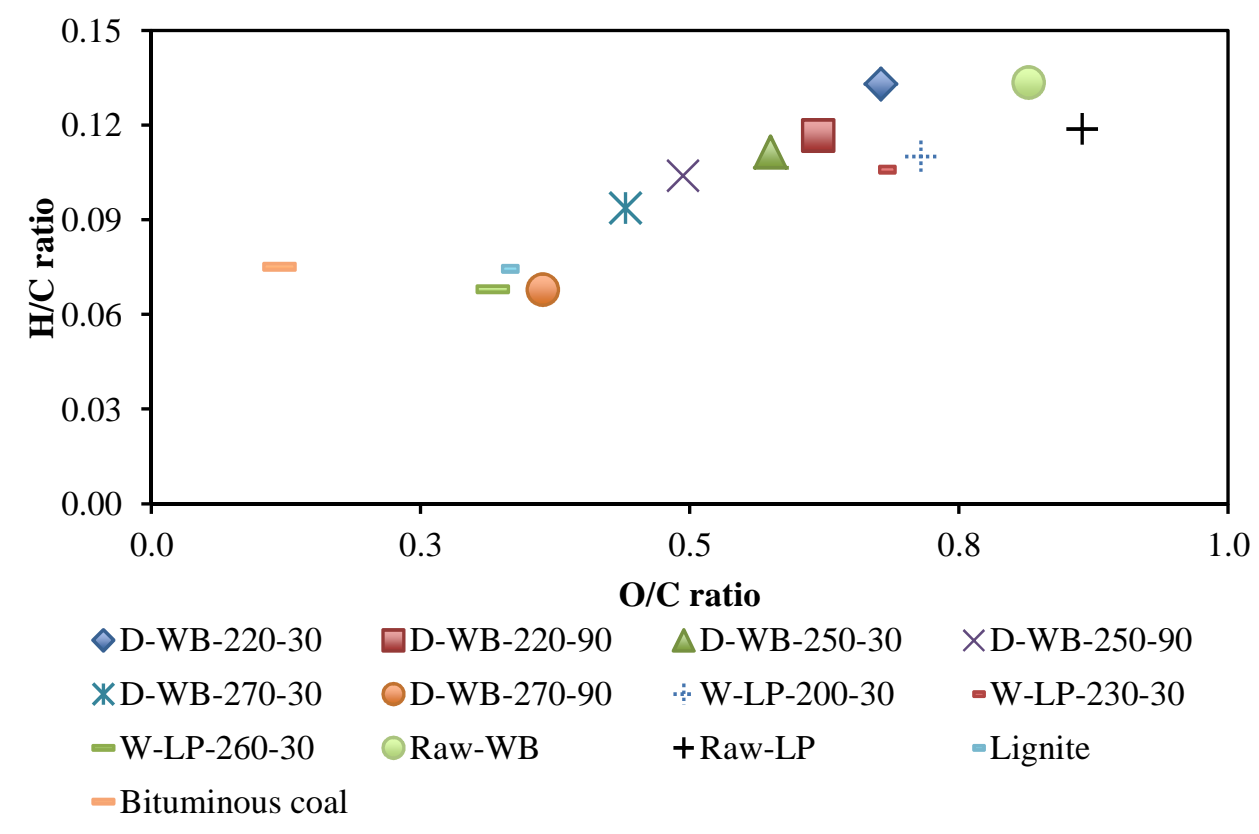

Figure 14: Van Krevelen Diagram of Different Fuels (Notation: Type of TorrefactionBiomass Type-Temperature-Time; $D=D$ ry Torrefaction; $W=W e t$ Torrefaction; $W B=$ Briquette of Wood (Felfli et al., 2005); LP= Loblolly Pine (Yan et al., 2010); and Lignite and Bituminous (McKendry, 2002))

An increase in the energy density of torrefied solid product could be expressed as an energy enhancement factor (EDF), which is defined as a ratio of higher heating value of torrefied to that of the raw biomass. This is different from the energy yield, but could be used to determine it. The energy yield of a torrefaction process also varies with the type of biomass. The biomass with higher lignin content produces higher energy yield because they have higher solid product yield, as well as a 
higher energy density enhancement factor. For instance, Bridgeman et al. (2008) observed the energy yields of $77 \%, 78 \%$ and $86 \%$ for wheat straw $(7.7 \%$ lignin), reed canary grass (7.6\% lignin), and willow (20\% lignin), respectively after they are torrefied at $270{ }^{\circ} \mathrm{C}$ for 30 minutes. The willow with $20 \%$ initial lignin content attained the energy density enhancement factor of 1.196 compared to 1.095 by reed canary grass and 1.118 by wheat straw.

\section{Hydrophobicity}

Torrefaction substantially removes both free and bound moisture of biomass. The free moisture inside capillaries of fibers shows the surface wetness, whereas the bound moisture determines the hydrophilic or hygroscopic (affinity for water) nature of biomass. Though, drying could remove the surface moisture as well as some of the bound moisture of biomass, its hydrophilic property makes it regain the moisture from the surrounding air when stored. Equilibrium moisture content (EMC) of raw biomass influences its hygroscopic nature. Lowering the EMC reduces the moisture absorbing capacity, and thereby increases the hydrophobicity of biomass. The equilibrium moisture content also depends on the chemical composition and functional groups of biomass (Acharjee et al., 2011). The EMC highly varies with the relative humidity of air. Table 9 shows how a variation in EMC of a hydrothermally torrefied biomass is influenced by the temperature and relative humidity of the air in an atmospheric pressure. The torrefaction process has a positive effect on the humidity uptake from the air. The torrefied pellets can be considered more hydrophobic than the reference biomass pellets. A higher torrefaction temperature also has a favorable influence on the hydrophobicity. The wood and straw pellets are known to disintegrate quite rapidly when exposed to water. After 15 minutes of immersion water, absorption in the wood pellet is $76 \%$ while that of the torrefied pellet reduces it to $55 \%$ (Torrent, 2011).

The ability to resist the bound moisture is known as a hydrophobic nature of biomass.
Hydrophobicity is also related to its ability to destruct hydrogen bonds. Decomposition of hydroxyl groups and lignin coating in biomass particles are believed to be the major causes of increasing hydrophobicity in torrefied biomass (Li et al., 2012). Torrefaction can reduce the EMC of biomass down to about 3\% (Lipinsky et al., 2002). Equilibrium moisture content is directly related to the moisture absorption capacity of biomass. Li et al. (2012) found a reduction in the moisture adsorption capacity from $20.7 \%$ wt. to $13.6 \%$ wt. in the torrefied pellets. Similarly, Sule (2012) analyzed the effect of the temperature on the moisture absorption capacity and they found about $20 \%$ drop in the moisture absorption when the torrefaction temperature increased from $230{ }^{\circ} \mathrm{C}$ to $270{ }^{\circ} \mathrm{C}$. the reduction in the moisture reabsorption capacity of biomass is due to the ability to break and remove carboxyl and hydroxyl groups during torrefaction. This type of pretreatment of biomass will be a good as it converts biomass into non-polar substances, which are less capable of forming hydrogen bonds. For instance, Shoulaifar et al. (2012) clearly noted a decrease in the EMC of torrefied spruce wood with a destruction of the carboxylic groups.

\section{Grindability}

Biomass possessing visco-elastic and plastic behaviors dissipates much energy before failure, increasing the energy cost of grinding (Repellin et al., 2010). The energy required for grinding process of any materials could be defined as its grindability. The main limitations in the grinding of the raw biomass are fibrous and tenacious natures, which create difficulties in the grinding. Thus, the process that reduces fibrous and tenacious behavior of biomass enhances the overall performance of the size reduction equipment.

Grindability is characterized by the nature of the particle size distribution, and the sphericity of the particles. Grindability is usually expressed by the Hardgrove Grindability Index (HGI) that measures the level of difficulty in the grinding solid 
sample into the powder form (Wu et al., 2012). The higher the value of HGI, the more easily a solid fuel can be reduced to the fine powder (Shang et al., 2012; Wu et al., 2012). The value of HGI of the torrefied biomass increases with the residence time and the torrefaction temperature ( $\mathrm{Wu}$ et al., 2012). This is due to the harder and more brittle nature of the torrefied product. Wu et al. (2012) speculates that the rearrangement of the structure and the depolymerization of different molecules during the thermal treatment are one of the reasons of producing such hard and brittle product. Shang et al. (2012), on the other hand, reported that the removal of the hemicellulose during the torrefaction process is the main reason of increasing the HGI value of the torrefied product than the raw biomass.

The decrease in the fibrous nature of the torrefied biomass produces more spherical and isolated particles when grinded. This improves in the co-milling and blending of biomass with coal, and then increases the co-firing potential of biomass in coal-fired power plants (Bridgeman et al., 2010). An increase in the sphericity of the particle or a decrease in the slenderness of particle was also presented in Arias et al. (2008). Figure 15 shows the changes in the particle size distribution of biomass torrefied at different residence time and torrefaction temperature. It shows that the fraction of the finest particle size $(<75 \mu \mathrm{m})$ is maximum at the torrefaction temperature of $280{ }^{\circ} \mathrm{C}$ and residence of 30 minutes.

As discussed before, the torrefaction with an ability to reduce fibrous nature in the torrefied biomass, it significantly reduces the energy required for grinding wood (Bergman et al., 2005). For instance, Svoboda et al. (2009) reported a decrease in the milling energy by 3-7 times than the untreated biomass. However it varies with operating conditions of the torrefaction. Repellin et al. (2010) found that the grinding energy of torrefied spruce is reduced to around $100 \mathrm{kWh} /$ tonne and $400 \mathrm{kWh} /$ tonne at $280{ }^{\circ} \mathrm{C}$ and $200{ }^{\circ} \mathrm{C}$, respectively compared with that of 750 $\mathrm{kWh} /$ tonne for the raw spruce. The energy required for grinding or milling also varies with the type of biomass, the level of the moisture content, and the extent of fineness. A decrease in a specific grinding energy by one-tenth (from 237.7 $\mathrm{kWh} /$ tonne to $23.9 \mathrm{kWh} /$ tonne) for pine chips, and one-sixth (from $236.7 \mathrm{kWh} / \mathrm{t}$ to $36.7 \mathrm{kWh} / \mathrm{t}$ ) for logging residues was noted when the biomass was torrefied at $300{ }^{\circ} \mathrm{C}$ for 30 minutes (Phanphanich and Mani, 2011). Similar results were also reported for rice straw and rape stalked in Deng et al. (2009). Figure 16 shows the changes in the specific grinding energy consumption, and the mean particle diameter of the pine chips, and the logging residues at different torrefaction temperatures. It shows that both mean particle size specific grinding energy consumption decreases with temperature. The effect was more prominent in the torrefied pine chips than in the logging residues.

Along with the grinding energy, the particle size distribution, sphericity and particle internal surface area also determine the flowability and combustion behavior in the co-firing plants (Tumuluru et al., 2011). The mean particle size of the ground torrefied biomass as shown in the Fig. 16 decreases with the torrefaction temperature (Deng et al., 2009; Phanphanich and Mani, 2011). The particle size distribution curve also skews more towards lower particle sizes at different torrefaction temperature compared to untreated biomass (Phanphanich and Mani, 2011; Repellin et al., 2010). Repellin et al. (2010) suggested a linear relationship between the particle size and the anhydrous weight loss during the torrefaction. The fineness of particle after the torrefaction of the raw biomass not only depends on the operating condition but also varies with the type of biomass. For example, Phanphanich and Mani (2011) found the fineness fraction of the particle $82 \%$ in the pine chips, and $51 \%$ in the logging residues. This difference in the fineness of the particle, though the solid product yields are similar for both pine chips and logging residues, is not well explained in literatures. Thus, torrefaction because of its potential to reduce the fibrous and tenacious nature, the net grinding energy, the slenderness ratio, and 
the particle size is being promoted as one of the important biomass pretreatment methods.

Table 9: Variation of the Equilibrium Moisture Content (EMC) with Hydrothermal Torrefaction Temperatures at Different Relative Humidity

\begin{tabular}{|l|l|l|l|}
\hline Materials & $\begin{array}{l}\text { Torrefaction } \\
\text { temperature }\left({ }^{\circ} \mathrm{C}\right)\end{array}$ & $\begin{array}{l}\text { EMC (\%) at relative } \\
\text { humidity } 11.3 \%\end{array}$ & $\begin{array}{l}\text { EMC (\%) at relative } \\
\text { humidity 83.6\% }\end{array}$ \\
\hline Raw biomass & - & $3.5 \pm 0.5$ & $15.6 \pm 0.9$ \\
\hline \multirow{3}{*}{ Torrefied biomass } & 200 & $1.8 \pm 0.5$ & $12.8 \pm 0.7$ \\
\cline { 2 - 4 } & 230 & $0.9 \pm 0.3$ & $8.2 \pm 0.7$ \\
\cline { 2 - 4 } & 260 & $0.4 \pm 0.3$ & $5.3 \pm 0.03$ \\
\hline
\end{tabular}

Note: $\mathrm{EMC}=\left(\mathrm{W}_{\mathrm{e}}-\mathrm{W}_{\mathrm{dry}}\right) / \mathrm{W}_{\mathrm{dry}}{ }^{*} 100 \%$; where $\mathrm{W}_{\mathrm{e}}$ and $\mathrm{W}_{\text {dry }}$ refer to weight of sample at equilibrium condition and the weight of bone dry sample, respectively.

Source: Adapted from Acharjee et al. (2011)

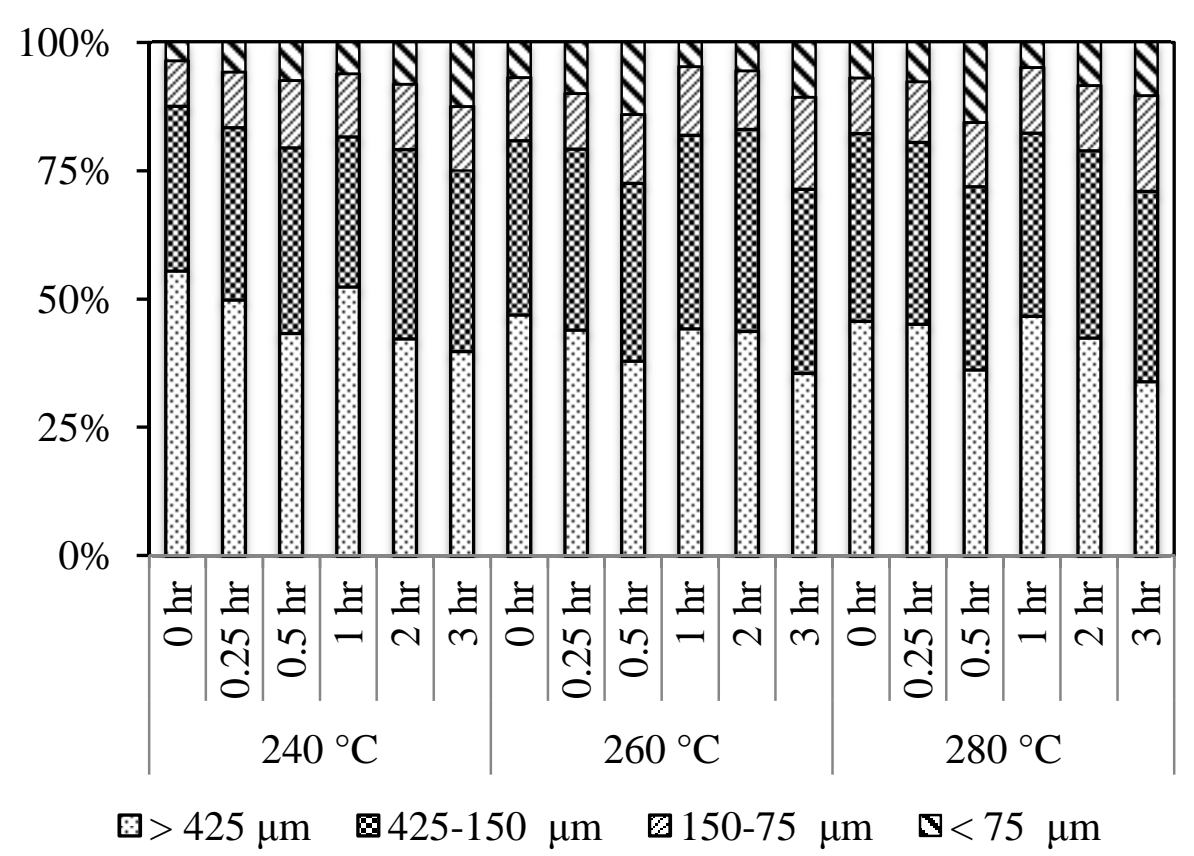

Figure 15: Distribution of Particle Size at Different Operating Conditions of Eucalyptus Wood (Particle Distribution of Raw Eucalyptus Wood 71\% >425; 18.7\%, 425-150; 4.7\%, 150-75; and $5.4 \%,<75$ )

Source: Adapted from Arias et al. (2008) 


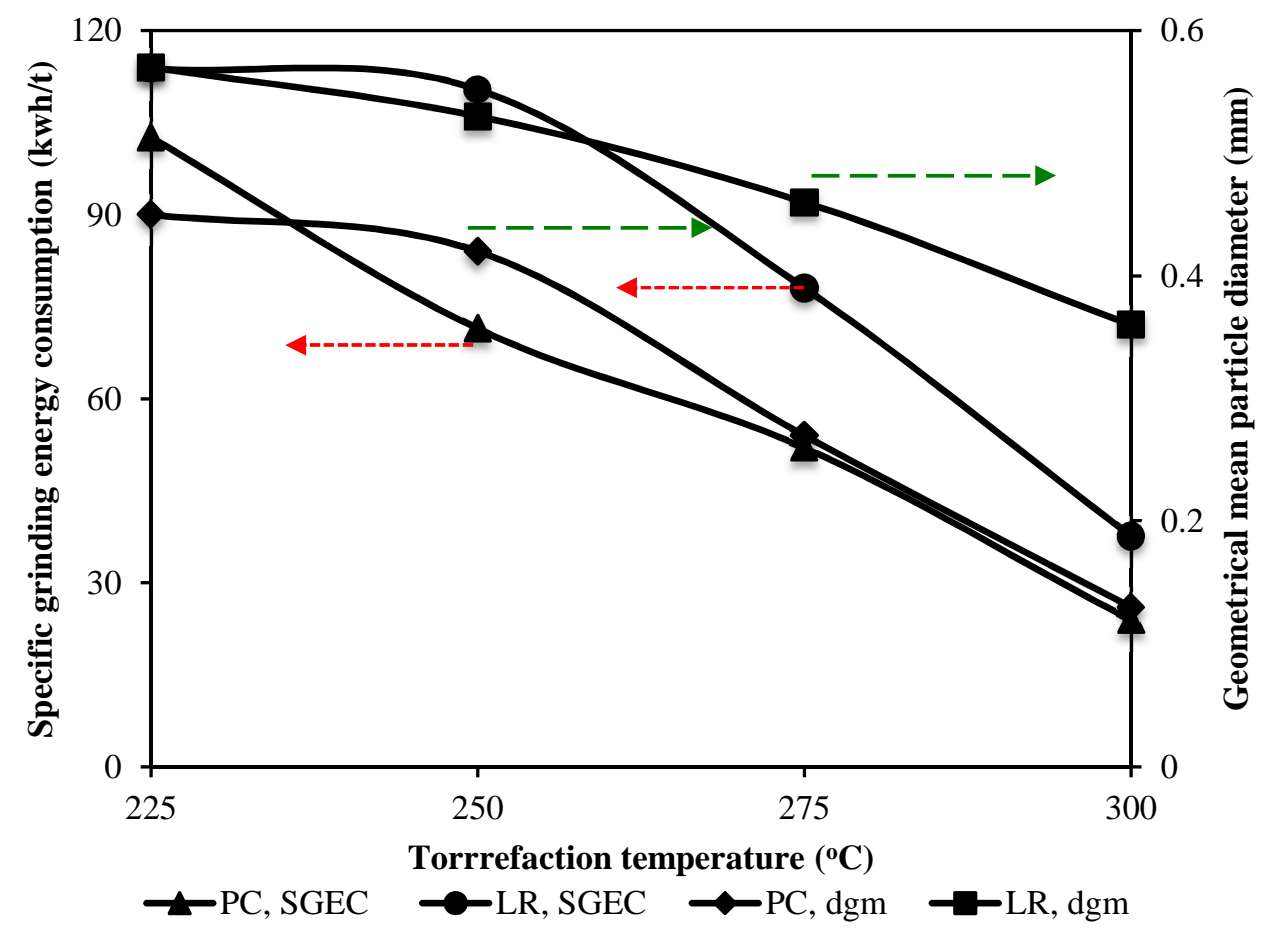

Figure 16: Temperature Effect on Specific Grinding Energy Consumption in kWh per Tonne and Geometrical Mean Particle Diameter of Pine Chips and Logging Residues Source: Adapted from Phanphanich and Sudhagar (2011)

\section{Density and Volume of Particle}

For the design of the biomass handling and the transport systems, a good knowledge of its density and volume change after torrefaction is necessary. The devolatilization process creates voids due to the escape of the volatiles and thereby, reduces density of the product. Shrinkage in the physical dimensions (length and diameter), which reduces volume of the product, also occurs during the biomass devolatilization process. It may reduce the extent of density reduction due to the mass loss. The shrinkage of solid is due to the loss of water, rearrangement of chemical bonds, and the coalescence of graphite nuclei within the solid structure (Moghtaderi, 2006). The shrinkage of particle is significant at high temperature $\left(1000-1300^{\circ} \mathrm{C}\right)$ pyrolysis and in thermally thick particles (Biot number $>10$ ) (Moghtaderi, 2006), but it may also be observed at a low temperature torrefaction. Only limited information is available on the impact of torrefaction in the shape and size of particle. A preliminary study of Basu et al. (2013a) found that both volume and density of the cylindrical poplar are reduced after the torrefaction process. They found that the decrease in the diameter was higher compared with that of the length of the product. They also reported that the changes in the dimension are due to the drying process below the fiber saturation point, and the devolatilization reactions causing to the damages in fibers. In addition to this, the density of torrefied product at a given torrefaction temperature was found higher in a slender particle with high length to diameter $(L / D)$ ratio. This is due to the higher solid product yield at a higher $L / D$ of the particle (Basu et al., 2013a).

Generally, the raw biomass swells because of moisture. The swelling of biomass occurs when the water vapor diffuses into cell lumen and then from the cell lumen to the cell wall. Swelling of woody biomass is a reversible process that continues to swell until the moisture level reaches to the fiber saturation point, and starts shrinking once 
it loses the moisture below that point (Rowell, 2005). The water molecules attracted by the hydroxyl groups of polymeric components of the lignocellulosic biomass also occupy the space between the cell wall components (Homan et al., 2012). The torrefaction process not only removes the moisture, but also increases the non-polar molecules in the wood through devolatilization and depolymerization reactions. This naturally brings some changes in the physical size of the particle.

Torrefaction reduces the bulk density of biomass, though because of its less sharp shape one would expect higher packing density. Torrefaction however, increases the porosity of biomass. The increase in the porosity reduces the density of the torrefied product. Changes in the density depend on the operating parameters of the torrefaction as well as the type of biomass. Figure 17 shows the variation in reduction of bulk density of biomass after torrefaction at different temperature and residence time. The porous product becomes more brittle, that significantly reduces the power required for the size reduction compared to that of the raw biomass. In addition to this, torrefaction reduces the slenderness of particle, increasing the sphericity of the ground particles.

\section{The Color of the Torrefied Products}

The color of biomass changes through torrefaction due to the losses of surface (free) moisture, bound moisture, and light volatile gases at different stages of torrefaction. The color of the torrefied biomass depends on the torrefaction conditions. For example, the color changes from brownish to dark when the treatment time and temperature are increased. Changes in wood color under the thermal treatment are mainly due to hydrolysis and oxidation reactions (Torres et al., 2010). The changes in color can also be used as an indicator of the degree of conversion (Bourgois et al., 1991). The color of torrefied biomass also depends on the type of the raw biomass (early wood or late wood) and their densities (Aydemir et al.,
2010). They also found that the color of wood, which is affected by the color of the extractives, also changes due to the variation in extractive compositions. The Changes and the transformation of the hemicellulose and lignin under the thermal degradation, which depends on $\mathrm{pH}$ level, moisture content, heating medium, exposure period, and type of species, produce a dark color in a product (White and Dietenberger, 2001). Sundqvist (2004) explained the changes in the color after the thermal treatment of biomass through absorption, reflection, or scattering phenomena of the visible light incident (380-800 nm) on the surface of wood. The grayish color of wood surface at the normal temperature is due to the high concentration of hemicellulose and cellulose that have higher scattering ability of incident light. On the other hand, the formation of different chromophoric groups such as carbonyls, hydroxyls, methoxyls, and phenolic compounds with an ability to absorb an incident light, and are also responsible for the dark color (Sundqvist, 2004). The color variations such as brown, purple, black, and redorange may be observed in the heartwood of different species, depending upon the type of phenolic compounds formed during the torrefaction viz. tannins, lignans, flavonoids, and quinones, respectively (Sundqvist, 2004). The chemical reactions forming the aldehydes and phenols also change the color of the products. Thus, depending upon the time and the temperature of thermal treatment, the color of the product changes from light brown to dark brown (Aydemir et al., 2010). Figure 18 shows the effect of temperature on the color of torrefied pine chips.

Furthermore, during the drying stage, the movement of the hydrophilic and lipophilic extractives towards the surface of wood produces a brown strain in softwoods (Torres et al., 2010). The color of the surface of wood is also affected by the concentration of the low-molecular-weight sugars, sugar alcohols, and nitrogenous compounds. An increase of the concentration of the low molecular weight sugars at the surface $(0-3 \mathrm{~mm})$ also 
influences the surface color (Terzie and Boutelje, 2007). The color response of wood under the hydrothermal treatment can be studied using the color coordinates
Lightness $\left(\mathrm{L}^{*}\right)$, Chroma $\left(\mathrm{C}_{\mathrm{ab}}{ }^{*}\right)$, hue $(\mathrm{h})$, and the color difference $\left(\Delta \mathrm{E}_{\mathrm{ab}}{ }^{*}\right)$ (Sundqvist, 2004).

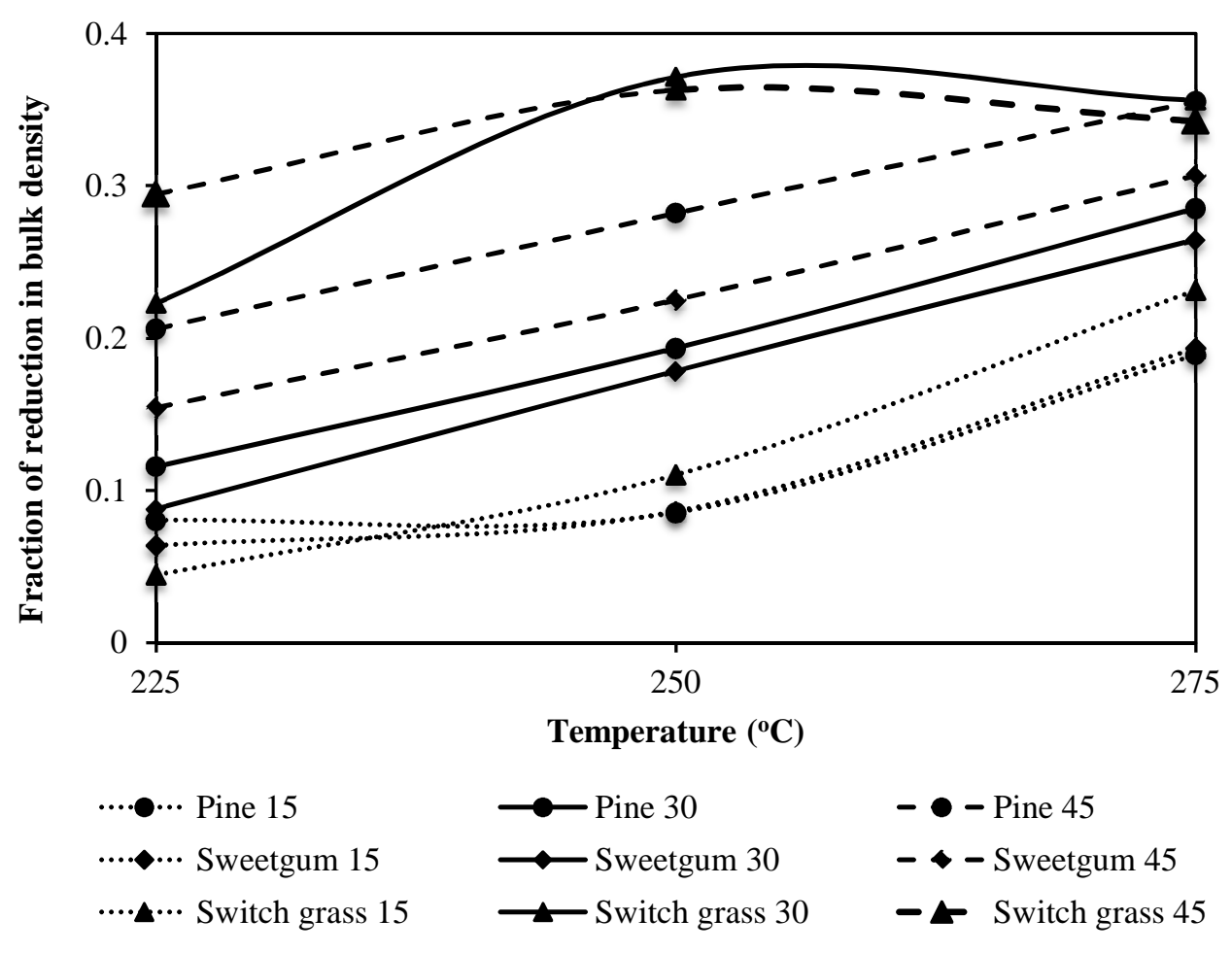

Figure 17: Variation in Fractional Reduction in Bulk Density after Torrefaction (Bulk Densities of Raw Pine, Sweet Gum and Switch Grass are 159.2, 182.1, and $117.1 \mathrm{~kg} / \mathrm{m}^{3}$, Respectively)

Source: Adapted from Carter (2012)

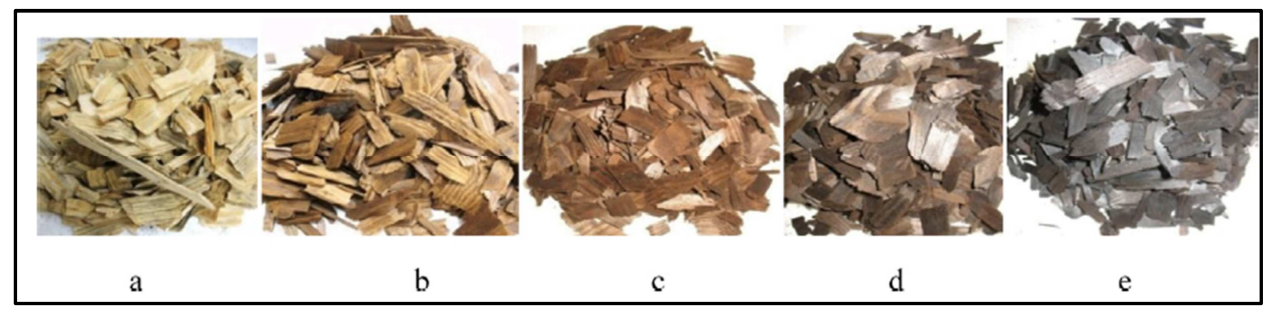

Figure 18: Effect of Temperature on the Color of Torrefied Pine Chips at (a) Raw, (b) 225 ${ }^{\circ} \mathrm{C}$, (c) $250^{\circ} \mathrm{C}$, (d) $275^{\circ} \mathrm{C}$, and (e) $300{ }^{\circ} \mathrm{C}$. Source: Phanphanich and Mani (2011)

The Effect of Torrefaction in Other Processes

\section{Pelletization}

Pelletization is a densification process that produces compacted products of desired shaped from biomass. It requires powdered biomass in designated particle sizes. This means that a biomass is easier to grind and makes a superior raw material for the biomass pelletization. Though, the pelletization avoids some of the major problems like transportation difficulties, low bulk density, low energy density, and handling complexity, the normal wood pellets will have a strong affinity towards the moisture and reabsorb the humidity 
from the surrounding air during the storage period. Torrent (2011) shows photographs of the raw biomass pellets and torrefied biomass pellets after both were soaked in water for 15 minutes. Owing to reabsorption of water raw biomass pellets nearly disintegrated, while the torrefied biomass pellets still retained its shape. Reabsorption of moisture enhances the physio-chemical degradation, as well as the microbial disintegration of biomass (Duncan et al., 2013). This limitation of the normal pellets is easily avoided by using a torrefied biomass as a feedstock.

Though, one expects the pelletization of torrefied wood to be easier because of an increase percentage of lignin after the torrefaction, in reality that does not necessary happens. $\mathrm{Li}$ et al. (2012) reported that the pelletization of the torrefied biomass is more energy intensive than the raw biomass. Due to the lack of the sufficient hydrogen bonds in the torrefied biomass, the pelletization process consumes more compression energy ( $\mathrm{Li}$ et al., 2012; Na et al., 2013; Stelte et al., 2011). The compression energy will increase while pelletizing dried biomass particles. The dried biomass materials are hard to plasticize, and possess a significant frictional resistance (Gilbert et al., 2009; Stelte et al., 2011). For example, the compression pressure in the pelletization process of the torrefied spruce increased by approximately 7 times that required for pellets from the raw spruce (Stelte et al., 2011). They also reported the adverse effect of the torrefaction temperature on the pellet quality.

One of the major advantages of producing pellet using torrefied biomass is its hydrophobic nature. Hydrophobicity of pellets increases with the increasing of the torrefaction temperature (Duncan et al., 2013; Li et al., 2012). The hydrophobicity of pellet increases when the pellets are produced using smaller particle size (Duncan et al., 2013). On the other hand, the pelletization followed by the torrefaction process is more energy efficient than a conventional pelletization process. The TOP process of ECN for wet sawdust shows that the volume of pellets production could reduce drastically for the same energy output in the TOP method (Agar and Wihersaari, 2012). In the TOP method, thermal energy input decreases by $50 \%$ of the thermal energy requirement of the conventional method.

Due to the lack of the hydroxyl groups of moisture and hemicellulose content, the bonds between individual particles in the torrefied pellet are also weaker compared to that for the normal pellets ( $\mathrm{Na}$ et al., 2013). Shang et al. (2012) noted that the strength of pellets from Scot Pine torrefied at $250{ }^{\circ} \mathrm{C}$ was significantly reduced, and the pellets are brittle, uneven, and non-uniform in the physical appearance. The brittle torrefied pellets are difficult to handle and transport because they are easily breakable, and produce dust (Gilbert et al., 2009). The durability of the torrefied pellet is low, and it decreases even more at higher torrefaction temperature. The mass fraction of the dust in pellets using torrefied biomass increases with the temperature (Gilbert et al., 2009).

\section{Gasification}

Biomass gasification is a clean and convenient option for biomass to the energy conversion. Some characteristics of the raw biomass could adversely affect the gasification process. For instance, the fibrous nature of biomass causes difficulties in pulverizing and feeding to the entrained flow gasification system (Erlach et al., 2012).

Additionally, biomass generally has higher $0 / C$ ratio than that in the coal. A feedstock with high $0 / C$ ratio increases the extent of the oxidation reactions in a gasifier, resulting in low gasification efficiency (Prins et al., 2006), as well as higher exergy loss. For example, gasification of biomass having high $0 / C$ ratio of 0.6 shows more exergy loss than that with coal and with low 0/C of 0.3 (Prins et al., 2007). So, a reduction in oxygen content of a biomass through torrefaction pretreatment prevents the potential of the oxidation reactions, increasing the suitability of biomass for the gasification process. 
As the torrefied biomass has low $0 / \mathrm{C}$ ratio and lower moisture level, one expects less oxidation reaction to convert $\mathrm{CO}$ to $\mathrm{CO}_{2}$. Solid fuels with low $\mathrm{O} / \mathrm{C}$ and $\mathrm{H} / \mathrm{C}$ ratios are also desirable in the gasification process due to its higher energy content (Yusup et al., 2013). The quality of the product gas depends highly on the chemical composition of the feedstock and the operating gasification temperature. For example, Prins et al. (2007) recommended an optimum gasification condition with $\mathrm{O} / \mathrm{C}$ of 0.4 and 0.3 at gasification temperatures of $927{ }^{\circ} \mathrm{C}$ and $1227{ }^{\circ} \mathrm{C}$ respectively. Additionally, a higher temperature in the gasification zone could be achieved due to relatively low moisture content in the torrefied biomass. This will enhance reforming reactions and increase $\mathrm{H}_{2}$ and $\mathrm{CO}$ concentration in the product gas. So the higher will be the torrefaction temperature, higher will be the $\mathrm{H}_{2}$ and $\mathrm{CO}$ concentration in the product gas.

Figure 19 shows the effect of torrefaction condition on the gasification product of the torrefied biomass. One notes here a variation in the composition of the product gas obtained from the gasification of the torrefied sawdust at different torrefaction temperature. It is also compared with that of the producer gas composition produced from the gasification of the raw biomass. Though, the cold gas efficiency of torrefied sawdust obtained at different torrefaction temperature is higher compared to that for raw sawdust, the torrefaction condition that produces the largest surface area, or develops the smallest pore size within the biomass shows significant effects on the gasification efficiency. For example, Qing et al. (2010) observed the highest cold gas efficiency from the torrefied sawdust at $250 \stackrel{\circ}{\circ}$. Interestingly, Prins et al. (2006) observed the reduction in the overall efficiency gasification for the torrefied wood compared with that of the raw biomass. Such reduction was even more significant when the gasification was carried using the torrefied biomass produced at a higher temperature. This may be due to the higher losses in the volatiles at the higher torrefaction temperature without adding their energy values in the product gas. Couhert et al. (2009) also observed a poor performance in the steam gasification at $1200{ }^{\circ} \mathrm{C}$ in a fixed bed reactor of torrefied wood compared with that of the gasification of the normal char. But, the quality of syngas, which is a ratio of sum of $\mathrm{H}_{2}$ and $\mathrm{CO}$ to $\mathrm{CO}_{2}$, improves significantly when the torrefied biomass produced at a higher temperature was used as a feedstock.

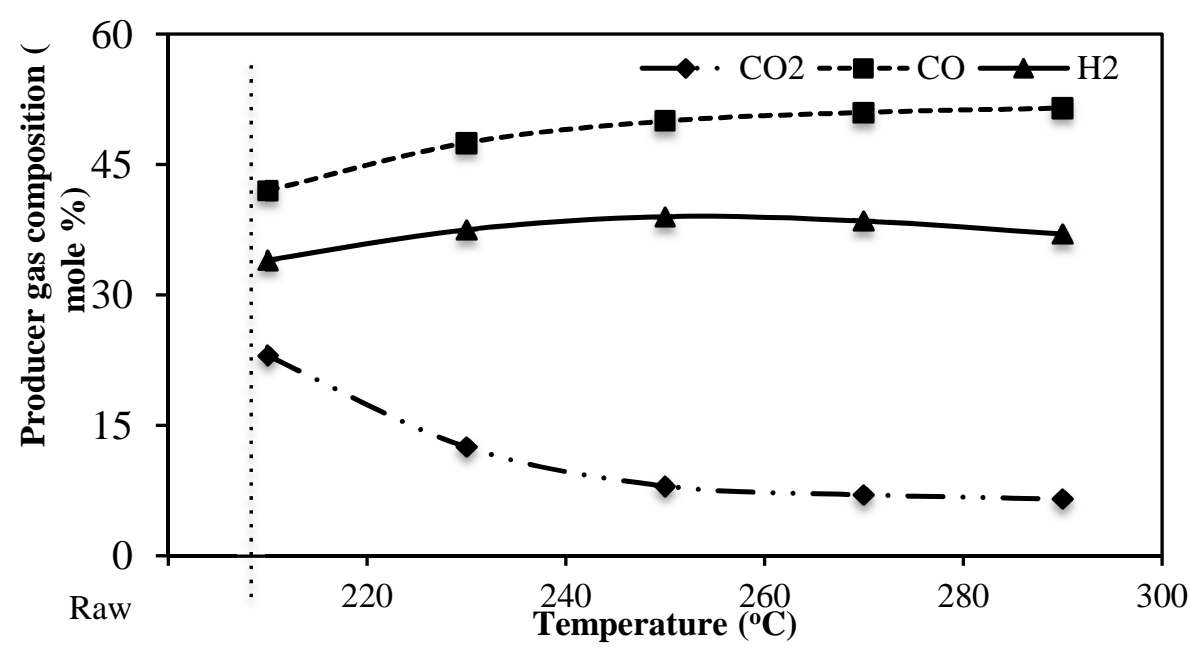

Figure 19: The Producer Gas Composition of the Torrefied Sawdust at Different Temperature (Residence Time 20 Min)

Source: Adapted from Qing et al. (2010) 
The exploratory work by Raut et al. (2013) showed that the tar production from the gasification of the torrefied biomass is lower than that from the gasification of the raw biomass. This is due to the breakdown of tar producing cellulose in biomass. Phanphanich and Mani (2011) found that due to this high hemi-cellulose and the lignin in the biomass produce more tar during the gasification. The torrefaction process reduces the lignocellulose structures of the raw biomass and minimizes the tar content. Furthermore, Prins et al. (2006) suggested that the controlled or the proper temperature of the torrefaction would minimize the pyrolysis of cellulose and avoid the tar formation.

The torrefaction of biomass could enhance the gasification process. Because of its ability to produce more small size and spherical particles compared with that of the raw biomass, the limitation of the entrained flow gasification could be avoided and thereby, increasing the performance of gasifier. For example, Tremel et al. (2012) found that the overall gasification efficiency and carbon conversion efficiency of the entrained flow gasifier was observed superior for the smaller $(80-160 \mu \mathrm{m})$ particles torrefied biomass compared with that of the larger $(160-250 \mu \mathrm{m})$ particles. This could help to use the torrefied biomass in the facility of the entrained flow coal gasification without any modifications.

The gasification rate, which varies with the local heterogeneous reaction between the char and gasifying agent, depends on an intrinsic reaction rate (Mani et al., 2011). The reaction rate of the char would depend mainly on the porosity of the particle or internal surface area. Higher, the internal surface area, easier it is to transport fluidizing media and heat into the particle core. It increases the conversion rate of char in the gasification process. Thus, the torrefaction that alters specific surface area of pores inside biomass will have greater impact in the gasification rate. The changes in the specific surface and cold gasification efficiency with torrefaction temperature are therefore closely related (Fig. 20). Figure 20 shows that the torrefaction of biomass at $250 \stackrel{\circ}{\circ} \mathrm{C}$ produces products with the maximum specific surface area and achieved the highest cold gas efficiency. The increase in the internal surface area enhances the heterogeneous reactions between the char and $\mathrm{CO}_{2} / \mathrm{H}_{2} \mathrm{O}$ and leads to a higher char conversion rate. The higher char conversion rate increases the gasification temperature, and thereby improves the quality of producer gas.

The combination of the torrefaction and gasification is similar to a two-stage pyrolysis and gasification (Qing et al., 2010). This follows the principle of twostage gasification in which the first stage (pyrolysis zone) uses syngas from second stage (gasification zone) as a heat source, and the second stage (gasification zone) uses the pyrolysis gas from the first stage as a heat source for the gasification reactions (Henrich et al., 2008). The combination of the torrefaction and the gasification minimizes the problem of integrating heat source for the torrefaction process. Figure 21 shows a typical coal cogasification integrated with the torrefaction system.

\section{Combustion}

The combustion is the most widely used conversion technique to release energy from a fuel. The main motive of torrefaction is to increase the share of biomass in power production and to decrease the emission level by avoiding coal use, the torrefied biomass should have combustion characteristics comparable to those for coal. This section presents a review of combustion issues of the torrefied biomass. 


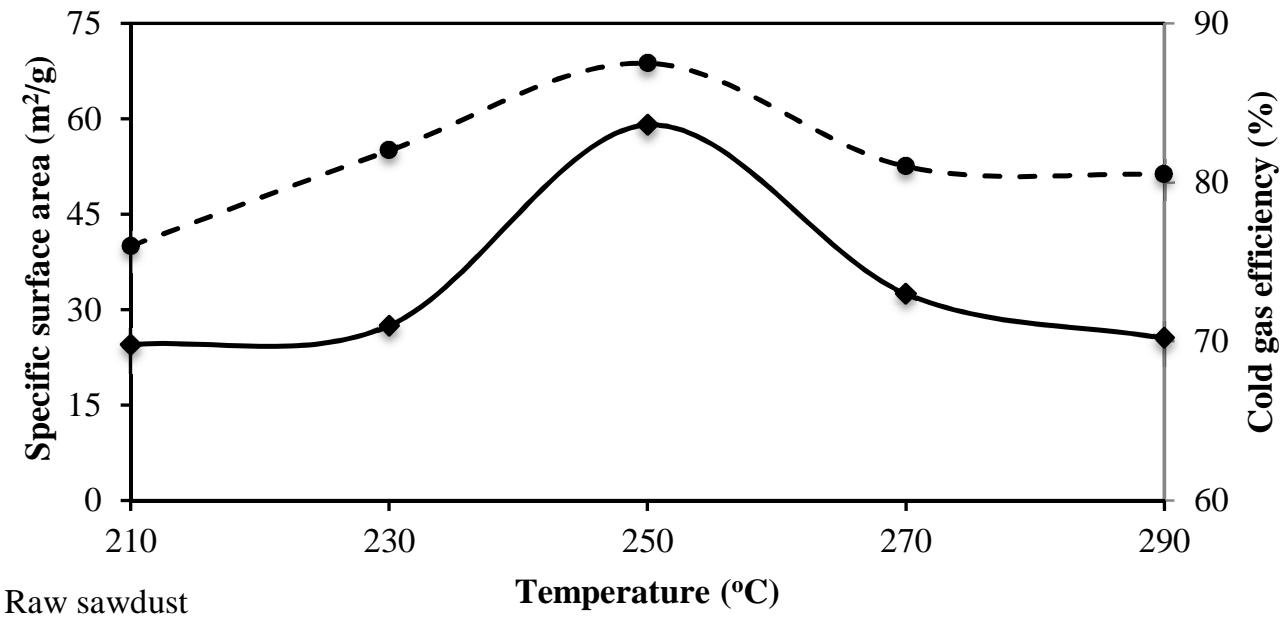

$\multimap$ Specific surface area $\quad-\bullet-$ Cold gas efficiency

Figure 20: The Effect of the Torrefaction Temperature on Cold Gas Efficiency and Specific Surface Area of Pores (Residence Time $30 \mathrm{Min}$ ) Source: Adapted from Qing et al. (2010)

Flue gas

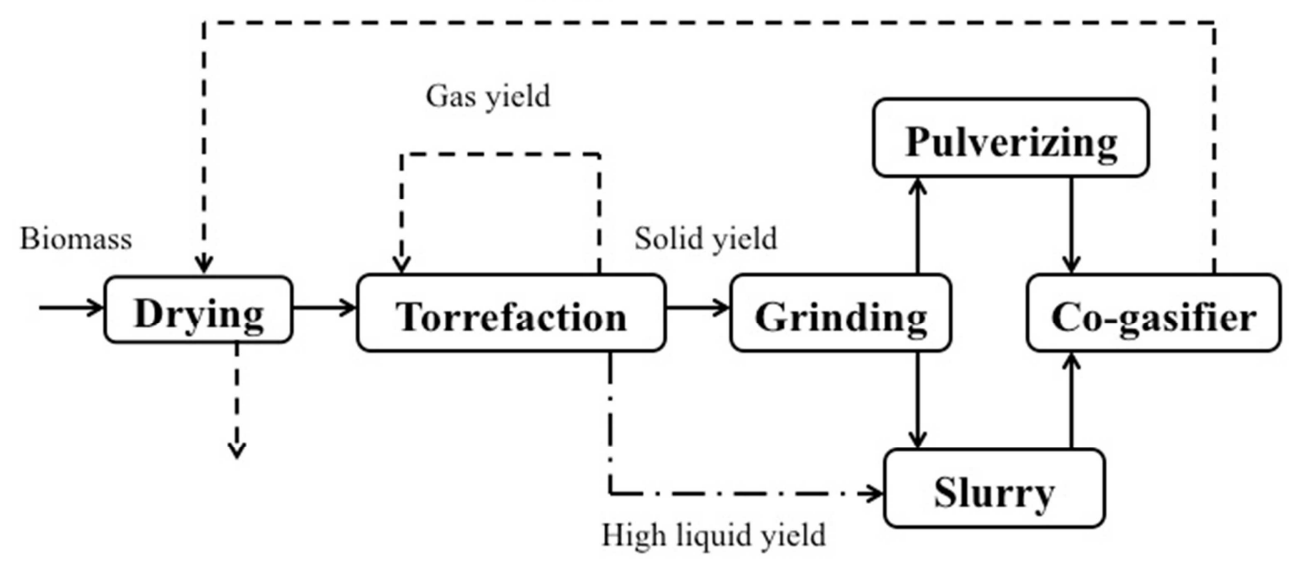

Figure 21: The Typical Auto-Thermal Torrefaction Integrated with the Coal CoGasification

Source: Adapted from Deng et al. (2009)

The Torrefied biomass is thermally more stable than the raw biomass, and it produces a higher heat of reactions during the combustion (Bridgeman et al., 2008). The exothermicity of torrefied sample is higher than that of the raw biomass and it increases with the severity of the torrefaction process. This is due to the higher quality of the volatile and porous char in the torrefied product. In their TGA studies Arias et al. (2008) found two distinct peaks of mass loss rate, representing combustion of the cellulose and lignin. The activation energy of the second stage combustion is not affected by the torrefaction condition as it is the combustion of the least reactive component - lignin. The activation energy of the first stage combustion increases with severity of torrefaction i. e. the temperature and the residence time.

The burnout rate of biomass decreases after the torrefaction because of the low volatile content in the torrefied biomass (Chen et al., 2012). The burning of the torrefied biomass takes longer time for the above reason, compared to that of the raw biomass. This effect is more prominent in the torrefied biomass at higher temperatures because of the higher volatile reduction potential. The burn out time is, 
however, shorter than that of coal (Chen et al., 2012) because of its more porous structure and remaining volatile matter. The decrease in the volatiles in the torrefied biomass may delay ignition of fuel in a pulverized coal fired boiler when torrefied biomass is combusted with coal. This may lead to accumulation of the unburnt fuel inside the furnace.

The char reactivity in the oxidation process decreases after the biomass is torrefied (Fisher et al., 2012; Jones et al., 2012). The decreased reactivity of the torrefied biomass could be explained through the accumulation of ash (the mineral content of the biomass) over the char surface. The accumulation of ash reduces the direct contact of the oxidation media with the carbon and increases the combustion time (Chan et al., 1999). Fisher et al. (2012) however reported that the char reactivity depends on how the volatile is removed from the original raw biomass. Volatiles matter and porosity are two major factors affecting the char reactivity. Since the volatile matter in torrefied, biomass is higher than that in the char from the raw biomass, the former is more reactive. However, the reactivity of char and torrefied biomass is higher than with that of coal. Reduction in an initial ignition temperature and an increment of burnout temperature of the torrefied coal are presented in Ge et al. (2013). They observed the maximum mass loss band shifted towards the high temperature zone. Typical combustion parameters of torrefied biomass produced by the hydrothermal torrefaction are also presented in Table 10.

\section{The Explosivity of the Torrefied Biomass}

An explosion of the fuel or dust is characterized by its rapid oxidation of combustible materials causing a sudden rise in temperature and pressure (Cashdollar, 2000) with resulting damage to lives and properties nearby. The dust explosion could be a major issue in handling the torrefied biomass as because of its brittle nature that can produce more dust than the raw biomass. The explosion potential depends on the type of the dust, the concentration of the dispersed dust particles, the combustion media, the area of suspension, and the heat source for ignition. An explosion of dust is only possible if there is five essential elements namely fuel, heat, oxygen, suspension, and confinement (Stephan, 2012.). For the dispersed dust cloud to ignite, the ambience in the confinement must reach the minimum temperature of the dust cloud. Furthermore, for ignition to sustain, the cloud must have a minimum dust concentration. Thus, two parameters that give an assessment of the likelihood of a dust explosion are:

a) Minimum ignition temperature of a dispersed cloud (MIT), and

b) Minimum explosible concentration (MEC).

The severity of an explosion after it occurs is determined by the maximum rate of pressure rise $\left(K_{s t}\right)$, and the maximum explosion pressure $\left(P_{\max }\right)$ (Cashdollar and Harazberg, 1987). 
Table 10: The Combustion Parameters of the Torrefied Biomass under the Hydrothermal Torrefaction (Residence Time $=30 \mathrm{Min}$ )

\begin{tabular}{|l|l|l|l|l|l|}
\hline Sample & $\begin{array}{l}\text { Ignition } \\
\text { Temperature, } \\
\mathrm{T}_{\mathrm{i}}\left({ }^{\circ} \mathrm{C}\right)\end{array}$ & $\begin{array}{l}\text { Temperature } \\
\text { at the } \\
\text { maximum } \\
\text { weight loss } \\
\text { rate, } \mathrm{T}_{\mathrm{m}}\left({ }^{\circ} \mathrm{C}\right)\end{array}$ & $\begin{array}{l}\text { Burnout } \\
\text { Temperature, } \\
\mathrm{T}_{\mathrm{b}}\left({ }^{\circ} \mathrm{C}\right)\end{array}$ & $\begin{array}{l}\text { Maximum } \\
\text { weight } \\
\text { loss, } \mathrm{R}_{\text {max }} \\
\left.\% /{ }^{\circ} \mathrm{C}\right)\end{array}$ & $\begin{array}{l}\text { Ignition } \\
\text { index, } \\
\left(10^{-2}\right)\end{array}$ \\
\hline $\begin{array}{l}\text { Coconut } \\
\text { fiber }\end{array}$ & 273 & 295 & 326 & 2.39 & 1.48 \\
\hline C-220 & 295 & 450 & 472 & 1.64 & 0.59 \\
\hline C-250 & 372 & 436 & 472 & 1.71 & 0.49 \\
\hline C-300 & 400 & 458 & 478 & 1.67 & 0.42 \\
\hline C-350 & 410 & 451 & 512 & 0.94 & 0.24 \\
\hline C-375 & 393 & 505 & 580 & 0.47 & 0.11 \\
\hline $\begin{array}{l}\text { Eucalyptus } \\
\text { leaves }\end{array}$ & 253 & 312 & 456 & 0.82 & 0.52 \\
\hline L-200 & 288 & 414 & 449 & 1.59 & 0.64 \\
\hline L-250 & 288 & 423 & 445 & 1.97 & 0.78 \\
\hline L-300 & 374 & 417 & 449 & 1.15 & 0.35 \\
\hline L-350 & 369 & 410 & 470 & 0.98 & 0.30 \\
\hline L-375 & 428 & 522 & 581 & 0.55 & 0.11 \\
\hline
\end{tabular}

Note: Ignition index, $\mathrm{D}_{\mathrm{i}}=\mathrm{R}_{\max } /\left(\mathrm{t}_{\max } \times \mathrm{t}_{\mathrm{i}}\right)$

Source: Adapted from Liu et al. (2013)

At the time of writing, no information on the incidence of the explosion in the torrefied biomass plant was known to have occurred, but several incidences of the biomass plant were known. For example, in June 2011 - an explosion occurred at the world's largest pellet manufacturing facility in Georgia, USA (Renewables-InternationalMagazine 2011). Though, a large amount of information on the explosion of the coal dust are available (Abbasi and Abbasi, 2007), a very little information on the explosion in the torrefied biomass dust is available in published literature. Andrej et al. (2013) and Huescar et al. (2013) compared the explosion potential of the raw biomass with those of the torrefied biomass and found that the torrefaction do not necessarily increase the explosion potential of its dust.

The torrefaction appears to have limited effect on the explosivity of the biomassdust especially when the particle sizes are below $150 \mu \mathrm{m}$. Though, the torrefaction temperature reduces the volatiles and makes biomass more brittle, Andrej et al. (2013) did not see much effect of this temperature on the explosion potential.
The MIT increased from $410{ }^{\circ} \mathrm{C}$ to only 430 ${ }^{\circ} \mathrm{C}$ when the torrefaction temperature rose from $200{ }^{\circ} \mathrm{C}$ to $300{ }^{\circ} \mathrm{C}$. Torrent (2011) measured the MIT of the torrefied biomass dust as $460{ }^{\circ} \mathrm{C}$ while, that for the wood dust is $420^{\circ} \mathrm{C}$. The MEC values for the raw and torrefied Poplar wood are $50 \sim 60 \mathrm{~g} / \mathrm{m}^{3}$. This is in contrast with the MEC of coal dust reported by Liu et al. (2010) in the range of $120 \mathrm{~g} / \mathrm{m}^{3}$. This may be due to the higher volatile matter in the biomass compared with that in the coal. Materials with higher volatiles will also produce more severe impact even at lower dust concentration. For instance, $\mathrm{Li}$ et al. (2012a) found that the anthracite, lignin, and bituminous coal produced an extreme overpressure at dust concentration of 500 $\mathrm{g} / \mathrm{m}^{3}, \quad 250 \mathrm{~g} / \mathrm{m}^{3}$, and $125 \mathrm{~g} / \mathrm{m}^{3}$, respectively. This also suggests that the anthracite with the lowest volatile matter requires the highest concentration of dust for the explosion. The typical effect of the volatile content of coal on the severity of the explosion is shown in Fig. 22. The increase in the volatile matter of fuel reduces the self-ignition temperature. For example, biomass with higher volatile content $(80-85 \%)$ has the self-ignition 
temperature of $302{ }^{\circ} \mathrm{C}$, whereas the torrefied biomass with less volatile content around $60-65 \%$ has $327-347$ o C (ECPI, 2012). The self-ignition temperature further increases to the range of 727-827 ${ }^{\circ} \mathrm{C}$ for the carbonized biomass with the volatile content of $10-12 \%$.

The MIT also depends on the nature of dust. The suspended dust as a cloud has higher MIT, compared with that of the dust in layer form. For example, the fuels with high volatile content have MIT of around $400{ }^{\circ} \mathrm{C}$ to the dust in the cloud form compared to $160{ }^{\circ} \mathrm{C}$ that the dust in the layer forms (Stephan, 2012). Variation in the MIT of coal dust, biomass, and torrefied biomass dust in cloud and layer forms is presented in Table 11. The risk of explosion increases significantly with the thickness of the dust layers as they have higher heat holding capacity.

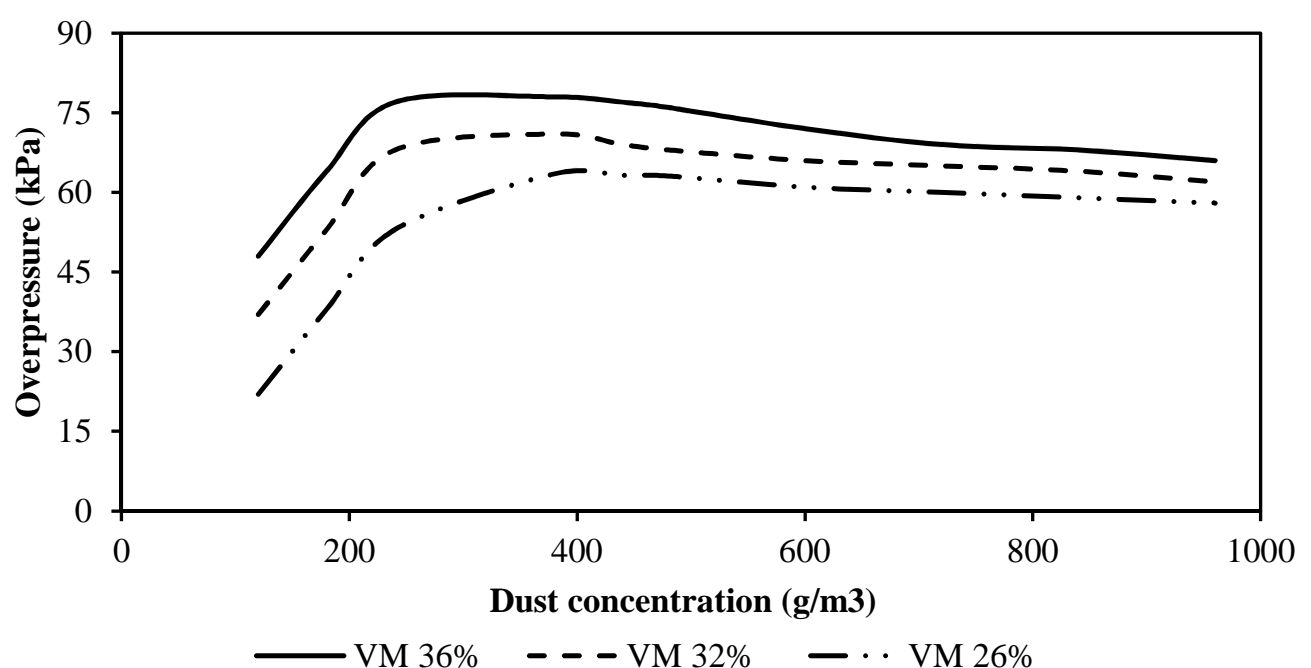

Figure 22: The Effect of the Volatile Content on the Overpressure in Dust Explosion (for a Given Suspension Density and Particle Size)

Source: Adapted from Liu et al. (2010)

Table 11: Variation of the Minimum Ignition Temperature of Different Type of Coal in Cloud and Layer Form

\begin{tabular}{|l|c|c|}
\hline \multirow{2}{*}{ Fuel type } & \multicolumn{2}{|c|}{ Minimum ignition temperature (oㅡ) } \\
\cline { 2 - 3 } & Cloud & Layer \\
\hline Pocahontas seam bituminous & 610 & 220 \\
\hline Wood dust & 420 & 340 \\
\hline Torrefied wood dust & 460 & 330 \\
\hline Pittsburgh seam bituminous & $525-560$ & 170 \\
\hline Sub-bituminous blend (as received) & 475 & - \\
\hline Sub-bituminous blend (dried) & 455 & - \\
\hline Lignite (as received) & $450-600$ & - \\
\hline Lignite (dried) & $425-555$ & 520 \\
\hline Rhode island (Cranston) anthracite & - & 160 \\
\hline Illinois No. 7 bituminous & - & \\
\hline Source: Adapted from (Stephan, 2012) & & \\
\hline
\end{tabular}

The porosity and the ability to produce the finer dust of the torrefied biomass than that of the raw biomass may increase the risk of the dust explosion. For example, the fuel (lignite) with an ability to produce more pores by releasing volatiles has 
better explosive reactivity than the fuel (anthracite) with lower volatile matter ( $\mathrm{Li}$ et al., 2012a). Very fine dust particles having high surface area to volume ratio are prone to the dust explosion phenomenon. The decrease in the dust particle size will reduce the MIT. Weigo et al. (2012) observed that the MIT for coal particle size range of 250-500 micron, 150250 micron, 75-150 micron, 48-75 micron, and $25-48$ micron is between $620-603{ }^{\circ} \mathrm{C}$, $590-600{ }^{\circ} \mathrm{C}, 580-590{ }^{\circ} \mathrm{C}, 560-570{ }^{\circ} \mathrm{C}$, and $520-530{ }^{\circ} \mathrm{C}$, respectively. For the sizes less than 75 micron, Huescar et al. (2013) however noted the negligible effect of the particle size, but they found that the MEC increased above 75 micron. Cashdollar (1996) noted a sharp rise in the MEC for the coal dust when the size exceeded 150 micron. This increase was higher for the torrefied biomass and smaller for the raw biomass.

The minimum Ignition Energy (MIE) is another important characteristic that influences the explosive potential of a dust cloud. The supply of minimum ignition energy (MIE) has much impact on the initiation of the dust explosion. The role of the MIE is even more in the explosion of carbonaceous materials such as biomass and coals, in which the explosion phenomenon influences greatly by the volatile content and its devolatilization rate (Kuai et al., 2013). The MIE measured for the torrefied wood dust was $160 \mathrm{~mJ}$, which is of the same magnitude as that of the other biomass dusts. Coal dust, on the other hand has a much higher MIE of the order of $>1000 \mathrm{~mJ}$.

Although, the research till the date found torrefied biomass no worse than biomass for explosion, the work being limited, more research is needed to settle this important question.

\section{The Commercial Development}

The torrefaction is originated as a process for toasting of coffee beans, nuts, and seeds in Ethiopia by using hot air in the temperature range 190-280 ${ }^{\circ} \mathrm{C}$ back in 1000 AD (Melin, 2011). Though, the thermal treatment of woods for improving the quality of the wooden furniture was established much earlier, its application to produce the energy denser biofuels was introduced only in 1987 in France. Guyonnet and Bourgois (1988) recognized the torrefied biomass as a good source for combustion and gasification process. Presently, a significant amount of research and development on the torrefaction is conducted as a thermal pretreatment method for upgrading biomass for the energy applications (ecoTech Energy Group, 2010). The global interest on the torrefaction is growing because of its potential for the substituting coal with carbon neutral biomass in pulverized coal power plants.

Because of the growing interest in the torrefaction process and its potential benefits, many organizations are working on the commercial development of the torrefaction. Many research centers, national governments and nongovernmental organizations around the world are working on the development and commercialization of different torrefier systems. Table 12 summarizes the major torrefaction reactors based on rotary drum, screw conveyor type, multiple heath furnace, torbed, microwave, compact moving, and oscillating belt conveyor reactors etc, developed by different organizations in Europe and North America. More details on the working principle and their diagrams are presented in Koppejan et al. (2012).

However for the commercialization of the torrefaction technology, the demand in the end use sector like a coal power plant needs to be balanced. This in turn depends to a great extent on the government legislation for curbing carbon emission from the power plants. The lack of such legislation has been a major deterrent to the current development of the torrefaction technology and facilities. On the other hand, the lack of both technical and economical clarity to run a large-scale plant still remains as an obstacle for the investors, policy makers, and the implementing organizations. To fill this gap, Pirraglia et al. (2013) have developed a techno-economic dynamic model that 
integrates mass balance, energy consumption, and rates of return, net present value, minimum revenue, and production costs. They found that the torrefaction reactor unit accounts for $60 \%$ of the total capital investment and it is highly sensitive parameter in the financial analysis. They also concluded that the scalability of the technology, risk assessment, maintenance costs, production rates, product quality, and the availability of the technology supplier greatly affects the total investment. However, the introduction of the carbon credit market could improve the financial indicator of investors like the internal rate of return, the payback period of the investment, and the business profitability.

\section{The Application of the Torrefied Biomass}

The major application of the torrefied biomass is in co-firing of biomass in coalfired power plants. The torrefied wood could ideally increases the share of the biomass feed up to $80 \%$ compared to 5$10 \%$ share of non-torrefied wood pellets (Topell, 2012). In addition to this, the torrefied biomass can also be used in different sectors such as an industrial furnace in a metallurgical process, as an activated carbon in water treatment, a metal extraction process, gas and air filtration process, and chemical treatment plants (Rautiainen et al., 2012). The potential application of the torrefied biomass in specific sectors and their requirements are presented in Table 13.

In the area of biofuel production, the quality of the bio-oil can be improved using the torrefied biomass because of the lower moisture and $0 / \mathrm{C}$ ratio. Such feedstock has the ability to produce a concentrated good quality bio-oil through a fast pyrolysis process (Meng et al., 2012).

Prando et al. (2013) studied a combined heat and power (CHP) system using the torrefied biomass in the gasification process. They found that the use of the torrefied biomass in gasifier could increase the overall efficiency of the CHP system, compared to that of using the raw biomass.
The torrefied biomass can be used also as an activated carbon - an adsorbent made from biomass, which is used to remove the organic or inorganic substances from the liquid and gases (Rautiainen et al., 2012). An activated carbon is a carbonaceous material with low volume pores. The low volume pore biomass with higher degree of micro-porosity possesses a higher contact surface area. It increases the combustion rate in flame burning, process, and enhances the adsorption capacity in a gas purification process. Since the porosity of the torrefied biomass depends on the temperature of torrefaction, the torrefied biomass obtained under a particular torrefaction condition, at which the microporosity reaches to the maximum value alone would be suitable for production of activated carbon.

In the metallurgical process like the iron making process, biomass could be used as a reducing agent to replace the coking coal (Basu, 2013). To replace the coking coal or oil by biomass, the latter needs to have high heating value, low volatile content, low ash and free from harmful elements, and particle size in the range of $1-10 \mathrm{~mm}$ (Fick et al., 2012). These characteristics can be obtained by converting biomass into either charcoal or torrefied biomass. One of the major benefits of using charcoal or torrefied biomass over coke is their ability to prevent sulfur dioxide emissions (Rautiainen et al., 2012). Though, the lower volatile content in the torrefied biomass increases its suitability over the raw biomass, they are usually not preferable compared to the charcoal.

A comparison of properties of torrefied biomass and other biomass fuels are presented in Table 14. A higher volumetric energy density and bulk density, low volatile contents and moisture content, uniform particle size, and homogenous nature of torrefied biomass are an important benefits in co-firing power plants. The major problems of in co-firing raw biomass in coal-fired plants include a large volume of flue gas, a rapid homogeneous combustion of volatiles resulting an unstable flame propagation and non-uniform heat distribution, and a 
low energy density of fuel requiring larger feeding system. Many of these can be greatly avoided after the torrefaction of biomass. In addition to this, co-firing with the torrefied biomass requires fewer modifications in the existing facility. Thus, it avoids the major capital expenditures that otherwise need to be made for retrofitting if the wood pellets are to be cofired (Koppejan et al., 2012).

\section{Torrefaction in the Context of Sustainable Development}

The growing energy demand, declining the fossil fuel resources and their greenhouse gas emissions, are the major motivations for adopting sustainable development practice.

The bio-char could serve as long-term sink of the atmospheric carbon dioxide (Glaser et al., 2002). The conversion of the biomass-carbon to the bio-char carbon leads to a sequestration of about $50 \%$ of the initial carbon in the biomass, this is significantly higher than the low fraction of parent carbon retained after the burning $(<3 \%)$, and the biological decomposition ( $<10-20 \%$ after $5-10$ years) (Lehmann et al., 2006). The large scale slash and burn the technique, though converts only small fraction $(3 \%)$ of the biomass carbon to the bio-char carbon, is widely practiced in agricultural fields in many countries because it has added the benefit of improving the soil property by retaining nutrients, and enhancing the soil physical and biological properties (Lehmann et al., 2006). This practice however, is highly polluting regionally as it emits the large amount of particulate and volatile organic compound.

More than $80 \%$ of the terrestrial organic carbon is stored in solids (IPCC, 2000). But soils show a low potential for additional accumulation of carbon compared with that of growing forest can absorb (Schlesinger and Lichter, 2001). The next best option is the conversion of biomass into the bio-char for a long-term sink in soil while simultaneously improving soil fertility and water retention capacity. This concept is not new. One can see evidences of such storage in the Amazon basin well before the european arrived there. Storage density of organic carbon there is as high as $250 \mathrm{Mg} / \mathrm{ha} / \mathrm{m}$ (Glaser et al., 2001).

The torrefaction, on the other hand, can provide a good alternative to the traditional means of bio-char production. First because of its low temperature (200$300{ }^{\circ} \mathrm{C}$ ), the larger fraction of the biomass char is retained in solid form. While nothing can be done about the noncondensable $\mathrm{CO}_{2}$ emissions, the condensable hydrocarbon, and $\mathrm{CH}_{4}$ can be burnt to provide energy for torrefaction. The present technology of torrefaction, however, is limited to the smaller scale production. It could be developed further into a large-scale production, which might be superior to the carbon-capturesequestration both in the cost and reliability.

To promote torrefaction as a low emission technology, it needs to be established that the technology is a net emission sink. To do this, one needs to determine the different sources of the emissions along the way. The emission level from a torrefier can be assessed by careful examination of its volatiles (tar and gases) products. Although the non-condensable gases could be used as an energy carrier, the condensable gases need to be properly managed to avoid a possible environmental issues. Some constituents of volatiles such as carbon monoxide, traces of hydrogen, and methane can be used as the source of energy, but volatiles like carbon dioxide ads to the GHG emissions. To minimize such emissions level, the University of Laval in Canada has recently investigated a study to capture the $\mathrm{CO}_{2}$ from torrefaction unit using mining waste. The study showed that $\mathrm{CO}_{2}$ from the torrefaction unit could be successfully captured and stored in magnesium rich ultramafic mining waste in a carbonation reactor. The other option is to use the $\mathrm{CO}_{2}$ rich low temperature flue gas in greenhouse farms for enhanced production and heating.

The combustion of torrefied biomass may have higher $\mathrm{CO}_{2}$ emission per unit energy release basis than that from the raw 
biomass, because of the higher carbon fraction in the torrefied biomass. This GHG emission can be better managed when the torrefaction is integrated with the co-firing plants. Torrefaction allows reduction in the coal/biomass ratio that reduces the overall emissions from power plants on per unit energy produced basis. In addition to this, torrefaction process will also avoid the emission by a natural decay of the raw biomass if left in the forest or so. Also, the transportation related emission decreases after the torrefaction, as it reduces the volume of materials to be transported for a given amount of energy transport.

Table 12: Summary of Recent Development on Torrefaction Reactors and Their Suppliers

\begin{tabular}{|c|c|c|c|c|c|c|}
\hline SN & Developer & $\begin{array}{l}\text { Name of } \\
\text { reactor }\end{array}$ & $\begin{array}{l}\text { Heating } \\
\text { mode }\end{array}$ & Technology & $\begin{array}{l}\text { Capacity } \\
\text { (tonnes/hr) }\end{array}$ & Country \\
\hline 1 & Torr-coal & Torr-coal & Indirect & Rotary drum & 4.5 & Netherlands \\
\hline 2 & 4 Energy & Stramproy & Direct & Belt conveyor & 5.5 & Netherlands \\
\hline 3 & Torrsys & Torrsys & - & - & 5 & USA \\
\hline 4 & EBES & ACB & Direct & Rotating drum & 1.5 & Germany \\
\hline 5 & Integro & Wyssmont & Direct & Multiple hearth & 2 & USA \\
\hline 6 & $\begin{array}{l}\text { West Creek } \\
\text { Energy }\end{array}$ & Konza & Direct & Rotary drum & 10 & USA \\
\hline 7 & Topell & Torbed & Direct & Toroidal & 8 & Netherlands \\
\hline 8 & ETPC & BioEndev & Indirect & Rotary drum & 4.3 & Spain \\
\hline 9 & BTG & BTG & Indirect & Screw conveyor & 5 & Netherlands \\
\hline 10 & Foxcoal & Foxcoal & Indirect & Screw conveyor & 4.2 & Netherlands \\
\hline 11 & Biolake & ECN & Direct & Moving bed & 5 & Netherlands \\
\hline 12 & Agritech & Torre-tech & Indirect & Screw conveyor & 5 & USA \\
\hline 13 & RFT & RFT & Indirect & Screw conveyor & 5 & USA \\
\hline 14 & Stramproy & Stramproy & Direct & $\begin{array}{l}\text { Oscillating belt } \\
\text { conveyor }\end{array}$ & 5 & Netherlands \\
\hline 15 & New Earth & ECO-PYRO & Direct & $\begin{array}{l}\text { Oscillating belt } \\
\text { conveyor }\end{array}$ & 2 & USA \\
\hline 16 & ECN & $\mathrm{BO} 2$ & Direct & Moving bed & 5 & Netherlands \\
\hline 17 & IDEMA & Thermya & Direct & Moving bed & 2.5 & France \\
\hline 18 & Atmoclear & Airless & Direct & Belt & 5 & UK \\
\hline 19 & CanBiocoal & Rotawave & Direct & Microwave & 12 & UK \\
\hline 20 & WPAC & WPAC & $\begin{array}{l}\text { Unknown } \\
\text { Technology }\end{array}$ & Unselected & 5 & Canada \\
\hline 21 & CDS & CDS & Direct & Rotating drum & - & UK \\
\hline 22 & BIO3D & BIO3D & Direct & Rotating drum & - & France \\
\hline 23 & CMI-NESA & CMI-NESA & Direct & Multiple hearth & - & Belgium \\
\hline 24 & $\begin{array}{l}\text { Allied } \\
\text { Blower }\end{array}$ & - & Indirect & Augers & - & - \\
\hline 25 & Alterna & Alterna & Direct & Tunnel & - & Canada \\
\hline 26 & Thermya & - & Direct & Moving bed & - & France \\
\hline 27 & Terradybe & & Direct & Not disclosed & - & Canada \\
\hline 28 & Torrfuels & SVI & Direct & Rotary drum & - & Canada \\
\hline 29 & Buhler & Buhler & Direct & $\begin{array}{l}\text { Compact } \\
\text { moving bed }\end{array}$ & - & USA \\
\hline 30 & AIREX & $\begin{array}{l}\text { CarbonFX } \\
\text { technology }\end{array}$ & Direct & $\begin{array}{l}\text { Cyclonic bed } \\
\text { reactor }\end{array}$ & 0.25 & Canada \\
\hline
\end{tabular}

Though, the interest in torrefaction as a pretreatment option for biomass has grown, only limited studies are available on the emission related issues. More studies on the technical and economical aspects of torrefaction are needed to analyze the effect of torrefaction on the GHG emissions. Chiueh et al. (2012) found that torrefaction had only a limited savings (3 US Dollar per $\mathrm{kg}$ of heat released) on the transportation 
cost of the raw biomass, from the source to the pretreatment plants, and then to the cofiring plants. However such conclusion cannot be drawn based on one work.

The savings in $\mathrm{CO}_{2}$ emission in some cases could be substantial with torrefaction. For example, Fick et al. (2012) found that 300 $\mathrm{kg}$ of $\mathrm{CO}_{2}$ equivalent per tonne of pig iron could be avoided by replacing $20 \%$ of the coke with the torrefied biomass. The total greenhouse gas emissions from different scenarios of fuel mix for producing one tonne of liquid iron are shown in Fig. 23. Because of the higher solid product of torrefaction, and the lower operating temperature compared to that in the conventional carbonization process, a switch to torrefaction process could be preferable for iron making without compromising the level of GHG emission savings obtained by the use of char.

Torrefaction could make similar positive contribution in the making use of biomass as a fuel healthier in the rural area of the developing countries. Many countries like
Nepal depend greatly on the biomass fuel in homes, but the resultant indoor air pollution remains a major issue. The increase in the indoor air pollution due to the inefficient use of biomass could increase the risk of respiratory tract infections, exacerbations of inflammatory lung conditions, cardiac events, stroke, eye disease, tuberculosis, and cancer (Fullerton et al., 2008). Though, it is believed that the high indoor air pollution resulted from the inappropriate ventilation, poor design of stoves, and inefficient burning, higher volatile content in biomass is the one that causes the excessive smoke. Biochar, which can be burnt efficiently with less smoke, is often promoted as an effective practical solution to address issues of fuel, health, climate, agricultural production, soil depletion, and poverty in the rural communities (NSWDPI, 2013). But, the torrefaction of biomass can also take this option on step further because of its higher mass and energy yield compared to the traditional biochar or charcoal production methods.

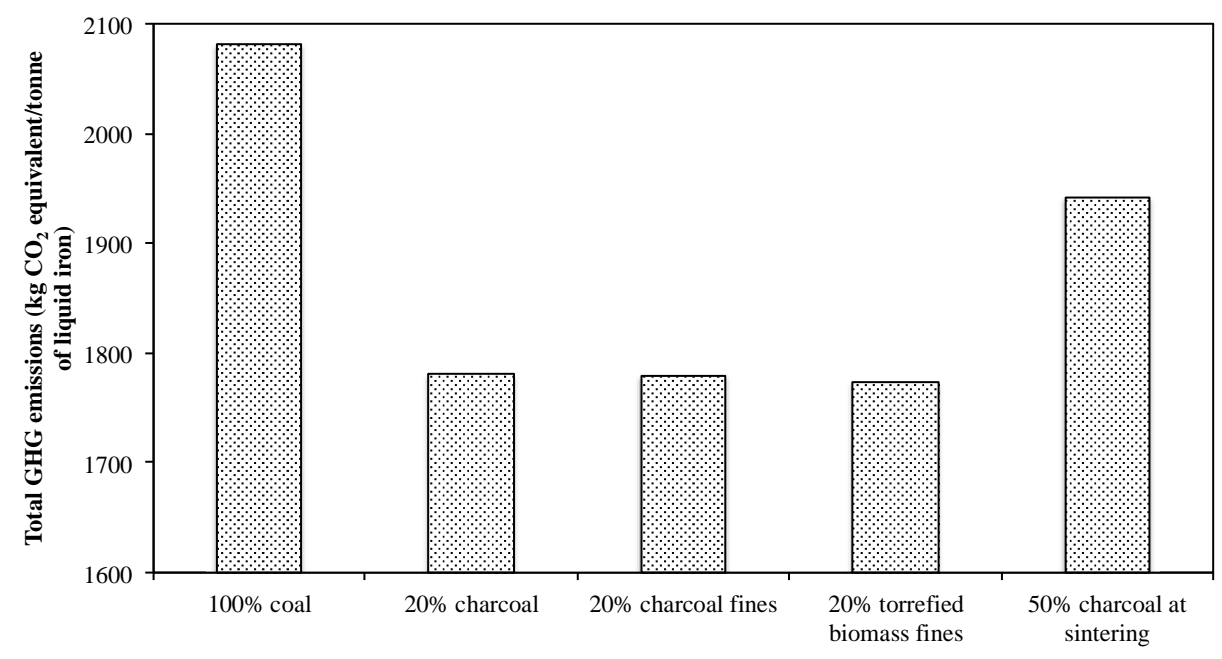

Figure 23: Different Scenarios of GHG Emissions in Steel Industry Source: Adapted from Fick et al. (2012)

\section{Conclusion}

Despite the huge potential of the biomass energy resource, it is not used as widely as it could be due to some of its inherent limitations such as the low energy density, low bulk density, heterogeneity, hygroscopic behavior and the fibrous nature, biomass. These limitations result in the transportation difficulties, the storage problem, and the spontaneous decay of biomass. Such problems could be substantially avoided through the torrefaction process. The Degradation of the hemicellulose is considered to be the main benefit of the torrefaction process. 
The decrease in the $\mathrm{O} / \mathrm{C}$ and $\mathrm{H} / \mathrm{C}$ ratio after torrefaction increases the energy density of biomass, and that makes biomass comparable with the coal. The increasing hydrophobicity of biomass through the torrefaction pretreatment process could make it acceptable for storage of biomass. Reducing the fibrous nature could increase the grindability of biomass that leads to a homogenous, spherical, and fine particle size distribution. The pelletization after the torrefaction could able to produce more uniform and hydrophobic products compared with that from the raw biomass. But, the pelletization of the torrefied biomass also requires higher compression energy. Pellets from the torrefied wood also needs more caring, as it is easily breakable. The torrefaction reduces the reactivity of biomass due to its low volatile content, but the fine particle size and the increased porosity in the torrefied biomass could lead to a higher cold gas efficiency of the gasification process. The increase in the initial ignition temperature and the stable burning are the major advantages for the combustion of the torrefied biomass. Because of the dusty environment while handling the torrefied biomass, it may seem to be more prone to the dust explosion, but limited experiments till the date does not support this speculation.

\section{Table 13: Application of Torrefied Biomass}

\begin{tabular}{|l|l|l|l|l|l|l|}
\hline Target & $\begin{array}{l}\text { Conversion } \\
\text { process }\end{array}$ & $\begin{array}{l}\text { Conversion } \\
\text { equipment }\end{array}$ & Biofuel & $\begin{array}{l}\text { Level of } \\
\text { pretreatment } \\
\text { requirement }\end{array}$ & $\begin{array}{l}\text { Benefit of } \\
\text { pretreatment }\end{array}$ & $\begin{array}{l}\text { Level of } \\
\text { market } \\
\text { potential }\end{array}$ \\
\hline & Co-firing & $\begin{array}{l}\text { Coal-fired } \\
\text { boilers }\end{array}$ & $\begin{array}{l}\text { Wood } \\
\text { pellets }\end{array}$ & High & $\begin{array}{l}\text { Higher co- } \\
\text { firing rates }\end{array}$ & High \\
\cline { 2 - 7 } $\begin{array}{l}\text { Large-scale power } \\
\text { production }\end{array}$ & $\begin{array}{l}\text { Co- } \\
\text { gasification }\end{array}$ & $\begin{array}{l}\text { Entrained } \\
\text { flow gasifier }\end{array}$ & $\begin{array}{l}\text { Wood } \\
\text { pellets }\end{array}$ & Very high & $\begin{array}{l}\text { Size } \\
\text { reduction, } \\
\text { uniform } \\
\text { particle } \\
\text { distribution, } \\
\text { C/H/O ratio, } \\
\text { dry and } \\
\text { hydrophobic }\end{array}$ & Limited \\
\cline { 2 - 7 } & Combustion* & $\begin{array}{l}\text { Fluidized } \\
\text { boilers }\end{array}$ & $\begin{array}{l}\text { Wood } \\
\text { chips }\end{array}$ & Moderate & $\begin{array}{l}\text { Limited and } \\
\text { relatively } \\
\text { expensive }\end{array}$ & Small \\
\hline Industrial heating & Combustion & Blast furnace & None & Moderate & $\begin{array}{l}\text { Easy } \\
\text { handling, } \\
\text { lower C/H/O } \\
\text { ratio, Energy } \\
\text { Content }\end{array}$ & High \\
\hline $\begin{array}{l}\text { Residential/district } \\
\text { heating }\end{array}$ & Combustion & Stoves/boilers & $\begin{array}{l}\text { Wood } \\
\text { pellets }\end{array}$ & $\begin{array}{l}\text { High, } \\
\text { decentralized }\end{array}$ & $\begin{array}{l}\text { Transport } \\
\text { savings }\end{array}$ & High \\
\hline
\end{tabular}

Source: Adapted from Koppejan et al. (2012)

Note: * 'combustion' implies $100 \%$ combustion of biomass 
Table 14: Comparison of Properties of Torrefied Biomass and Other Solid Fuels

\begin{tabular}{|c|c|c|c|c|c|c|}
\hline Parameters & Wood & Wood pellet & Coal & $\begin{array}{l}\text { Torrefied } \\
\text { biomass (dry } \\
\text { torrefaction) }\end{array}$ & $\begin{array}{l}\text { Hydrochar } \\
\text { (Hydrotherm } \\
\text { al } \\
\text { torrefaction) }\end{array}$ & $\begin{array}{l}\text { Hydrochar + } \\
\text { coal fines } \\
\text { (PCS hybrid } \\
\text { biofuels) }\end{array}$ \\
\hline $\begin{array}{l}\text { Moisture (wt. } \\
\% \text { ) }\end{array}$ & $30-40$ & $8-10$ & $6-15$ & $2-3$ & $4-5$ & $6-7$ \\
\hline $\begin{array}{l}\text { Higher heating } \\
\text { values }(\mathrm{MJ} / \mathrm{kg} \text { ) }\end{array}$ & $9-12$ & $16-19$ & $18-30$ & $20-25$ & $24-34$ & $24-27$ \\
\hline $\begin{array}{l}\text { Volatile } \\
\text { content (wt. \% } \\
\text { db) }\end{array}$ & $70-75$ & $70-75$ & $15-30$ & $55-65$ & NA & NA \\
\hline $\begin{array}{l}\text { Fixed carbon } \\
\text { (wt. \% db) }\end{array}$ & $20-25$ & $20-25$ & $50-55$ & $28-35$ & NA & NA \\
\hline $\begin{array}{l}\text { Ash content } \\
\text { (wt. \% db) }\end{array}$ & $<5$ & $<5$ & $6-15$ & NA & $0.3-0.5$ & $5-7$ \\
\hline $\begin{array}{l}\text { Bulk density } \\
\left(\mathrm{kg} / \mathrm{m}^{3}\right)\end{array}$ & $200-250$ & $550-750$ & $800-850$ & $700-850$ & NA & NA \\
\hline $\begin{array}{l}\text { Volumetric } \\
\text { energy density } \\
\left(\mathrm{GJ} / \mathrm{m}^{3}\right)\end{array}$ & $2-3$ & $7.5-10.4$ & $18.4-23.8$ & $15-18.7$ & NA & NA \\
\hline Explosibility & Average & Limited & Limited & Limited & NA & NA \\
\hline $\begin{array}{l}\text { Water } \\
\text { resistant }\end{array}$ & Hydrophilic & Hydrophilic & Hydrophobic & Hydrophobic & Hydrophobic & Hydrophobic \\
\hline $\begin{array}{l}\text { Biological } \\
\text { decay }\end{array}$ & Yes & Yes & No & No & No & No \\
\hline $\begin{array}{l}\text { Milling } \\
\text { requirements }\end{array}$ & Special & Special & Classic & Classic & Classic & Classic \\
\hline $\begin{array}{l}\text { Handling of } \\
\text { fuel }\end{array}$ & Special & Easy & Easy & Easy & Easy & Easy \\
\hline $\begin{array}{l}\text { Transportatio } \\
\mathrm{n} \text { cost }\end{array}$ & High & Average & Low & Low & Low & Low \\
\hline $\begin{array}{l}\text { Quality } \\
\text { variability }\end{array}$ & High & Limited & Limited & Limited & NA & NA \\
\hline Tar and cresol & Yes & Yes & Yes & No & No & Negligible \\
\hline Heavy metals & No & No & Yes & No & No & Negligible \\
\hline Sulfur & No & No & Yes & No & No & No \\
\hline
\end{tabular}

Source: Adapted from Acharya et al. (2012); Koppejan et al. (2012); PCSB (2011)

\section{References}

Abbasi, T. \& Abbasi, S. A. (2007). "Dust Explosions-Cases, Causes, Consequences, and Control," Journal of Hazardous Materials, 140 (1-2) 7-44.

Acharjee, T. C., Coronella, C. J. \& Vasquez, V. R. (2011). "Effect of Thermal Pretreatment on Equilibrium Moisture Content of Lignocellulosic Biomass," Bioresource Technology, 102(7) 4849-4854.

Acharya, B. (2013). "Torrefaction and Pelletization of Different Forms of Biomass," M.Sc Thesis, School of Engineering, University of Guelph, Ontario, Canada.
Acharya, B., Sule, I. \& Dutta, A. (2012). “A Review on Advances of Torrefaction Technologies for Biomass Processing," Biomass Conversion Refineries, 2 349-369.

Agbor, V. B., Cicek, N., Sparling, R., Berlin, A. \& Levin, D. B. (2011). "Biomass Pretreatment: Fundamentals toward Application," Biotechnology Advances 29 675-685.

Agar, D. \& Wihersaari, M. (2012). "Torrefaction Technology for Solid fuel Production," Opinion, Global Change Biology Bioenergy, 4 475-478. 
Akin, D. E., Rigsby, L. L., Sethuraman, A., Morrison, W. H., Gamble, G. R. \& Eriksson, K. E. (1995). "Alterations in Structure, Chemistry, and Biodegradability of Grass Lignocellulose Treated with the White Rot Fungi Ceriporiopsis Subvermispora and Cyathus Sterocoreus," Applied and Environmental Microbiology, 61(4) 15911598.

Almeida, G., Brito, J. O. \& Perre, P. (2010). "Alterations in Energy Properties of Eucalyptus Wood and Bark Subjected to Torrefaction: The Potential of Mass Loss as a Synthetic Indicator," Bioresources Technology, 101 9778-9784.

Andrej, B., Basu, P. \& Amyotte, P. (2013). 'An Exploratory Study of Explosion Potential of Dust from Torrefied Biomass,' Not published.

Arias, B., Pevida, C., Fermoso, J., Plaza, M. G., Rubiera, F. \& Pis, J. J. (2008), "Influence of Torrefaction on the Grindability and Reactivity of Woody Biomass," Fuel Processing Technology, 89 169-175.

Aydemir, D., Gunduz, G. \& Ozden, S. (2010). "The Influence of Thermal Treatment on Color Response of Wood Materials," Color Research and Application, Wiley Periodicals Inc., 148-153. Retrieved at http://onlinelibrary.wiley.com/store/10.1 002/col.20655/asset/20655_ftp.pdf?v=1an $\mathrm{dt}=$ hg2vaya4ands $=4 \mathrm{dc} 95 \mathrm{dab} 957 \mathrm{f} 27 \mathrm{~b} 7 \mathrm{a} 1 \mathrm{c} 4$ b72b31533dd9ced61a3f, 29th April 2013.

Basu, P. (2010). Biomass Gasification and Pyrolysis: Practical Design and Theory, ISBN 978-0-12-37488-8, Elsevier Inc., Burlington

Basu, P. (2013). Biomass Gasification, Pyrolysis and Torrefaction: Practical Design and Theory, ISBN 978-0-12396488-5, Academic Press, London.

Basu, P. \& Kaushal, P. (2009). "Modeling of Pyrolysis and Gasification of Biomass in Fluidized Beds: A Review," Chemical Product and Process Modeling, 4(1) Article 21.
Basu, P., Dhungana, A., Rao, S. \& Acharya, B. (2013). "Effect of Oxygen Presence in Torrefier," Journal of the Energy Institute.

Basu, P., Rao, S. \& Dhungana, A. (2013a). "An Investigation into the Effect of Biomass Particle Size on its Torrefaction," The Canadian Journal of Chemical Engineering, 91(3) 466-474.

Bates, R. B. \& Ghoniem, A. F. (2012). "Biomass Torrefaction: Modeling of Volatiles and Solid Product Evolution Kinetics," Bioresource Technology, 124 460469.

Bates, R. B. \& Ghoniem, A. F. (2013). "Biomass Torrefaction: Modeling of Reaction Thermochemistry," Bioresource Technology, 134 331-340.

Ben, H. \& Ragauskas, A. J. (2012). "Torrefaction of Loblolly Pine," Green Chemistry, 14 72-76.

Bergman, P. C. A. (2005). "Combined Torrefaction and Pelletization: The TOP Process," Energy Research Center of the Netherlands, Petten, Netherland. Retrieved at

http://www.ecn.nl/docs/library/report/2 005/c05073.pdf, 29th May 2012.

Bergman, P. C. A., Boersma, A. R., Kiel, J. H. A., Prins, M. J., Ptasinski, K. J. \& Janseen, F. J. J. G. (2005). "Torrefaction for Entrainedflow Gasification of Biomass," A research carried out in collaboration between the Technical University of Eindhoven and the Energy research Center of the Netherlands (ECN), Petten, Netherlands.

Bergman, P. C. A., Boersma, A. R., Zwart, R. W.R. \& Kiel, J. H. A. (2005a). "Torrefaction for Biomass Co-Firing in Existing CoalFired Power Stations-Biocoal," A research carried out in collaboration between the DEN Programs of SenterNovem, and the Energy research Center of the Netherlands (ECN), Petten, Netherlands. 
Bergman, P. C. A. \& Kiel, J. H. A. (2005). "Torrefaction for Biomass Upgrading," Conference Proceedings of 14th European Biomass Conference and Exhibition, Paris, France, 17-21 October, (2005), Energy Research Center of the Netherlands (ECN), Netherland. Retrieved at http://www.ecn.nl/docs/library/report/2 005/rx05180.pdf, 30th April 2013.

Bi, T. (2012). 'Torrefaction and Densification of Biomass,' Presentation, Biomass and Bioenergy Research Group, Clean Energy Research Center, University of British Columbia, 20th March 2012.

Bourgois, J. \& Guyonmet, R. (1988). "Characterization and Analysis of Torrefied Wood," Wood Science and Technology, 22 143-155.

Bourgois, P. J., Guyonment, R. \& Janin, G. (1991). "The Color Measurement: A Fast Method to Study and to Optimize the Chemical Transformations Undergone in the Thermally Treated Wood," Holzforschung, 45 377-382. In: Sundqvist, B. (2004). "Color Changes and Acid Formation in Wood during Heating," Doctoral Thesis, Division of Wood and Material Science, Lulea University of Technology. Retrieved at http://epubl.luth.se/1402-

1544/2004/10/LTU-DT-0410-SE.pdf, 29th April 2013.

Brebu, M. \& Vasile, C. (2009). 'Thermal Degradation of Lignin-A Review,' Cellulose Chemistry and Technology, 44 (9) 353-363.

Bridgeman, T. G., Jones, J. M., Shield, I. \& Williams, P. T. (2008). "Torrefaction of Reed Canary Grass, Wheat Straw and Willow to Enhance Solid Fuel Qualities and Combustion Properties," Fuel, 87 844-856.

Bridgeman, T. G., Jones, J. M., Williams, A. \& Waldron, D. J. (2010). "An Investigation of the Grindability of the Torrefied of Energy Crops," Fuel, 89 3911-3918.

Buranov, A. U. \& Mazza, G. (2008). "Lignin in Straw of Herbaceous Crops," Industrial Crops and Products, 28 237-259.
Cao, W., Huang, L., Zhang, J., Xu, S., Qiu, S. \& Pan, F. (2012). "Research on Characteristics Parameters of Coal-Dust Explosion," 2012 International Symposium on Safety Science and Technology, Procedia Engineering (2012), 45 442-447.

Cashdollar, K. L. (1996). "Coal Dust Explosibility," Journal of Loss Prevention in the Process Industries, 9(1) 65-76.

Cashdollar, K. L. (2000). "Overview of Dust Explosibility Characteristics," Journal of Loss Prevention in the Process Industries, 13 183-199.

Cashdollar, K. L. \& Hertzberg, M. (1987). "Industrial Dust Explosions," ASTM, 1987.

Carter, C. L. (2012). "Physicochemical Properties and Thermal Decomposition of Torrefied Woody Biomass and Energy Crops," Master Thesis, University of Auburn, USA.

Chan, M. L., Jones, J. M., Pourkashanian, M. \& Williams, A. (1999). "The Oxidative Reactivity of Coal Chars in Relation to Their Structure," Fuel, 78 1539-1552.

Chaouch, M., Petrissans, M., Petrissans, A. \& Gerardin P. (2010). "Use of Wood Elemental Composition to Predict Heat Treatment Intensity and Decay Resistance Different softwood and Hardwood Species," Polymer Degradation and Stability, 95 (12) 2255-2259.

Chaturvedi, V. \& Verma, P. (2013). "An Overview of Key Preatreatment Processes Employed for Bioconversion of Lignocellulosic Biomass into Biofuels and Value Added Products," Biotech, 3(5) 415431.

Chen, Q., Zhou, J. S., Lieu, B. J., Mei, Q. F.. \& Luo, Z. Y. (2010). "Influence of Torrefaction Pretreatment on Biomass Gasification Technology. Special Topic: Bioenergy, Energy Science and Technology," Chinese Science Bulletin, 56 1449-1456. 
Chen, W.- H., Du, S.- W., Tsai, C.- H. \& Wang, Z.- Y. (2012). "Torrefied Biomasses in a Drop Tube Furnace to Evaluate Their Utility in Blast Furnaces," Bioresource Technology, 111 433-438.

Chen, W.- H., Hsu, H.- C., Lu, K.- M., Lee, W.J. \& Lin, T.- C. (2011). "Thermal Pretreatment of Wood (Lauan) Block by Torrefaction and its Influence on the Properties of the Biomass," Energy, 36 3012-3021.

Chen, W.- H. \& Kuo, P.- C. (2010). “A Study on Torrefaction of Various Biomass Materials and its Impact on Lignocellulosic Structure Simulated by a Thermogravimetry," Energy, 35 25802586.

Chen, W.- H. \& Kuo, P.- C. (2011). "Torrefaction and Co-Torrefaction Characterization of Hemicellulose, Cellulose and lignin as Well as Torrefaction of Some Basic Constituents in Biomass," Energy, 36 803-811.

Chiueh, P.- T., Lee, K.- C., Syu, F.- S. \& Lo, S.L. (2012). "Implications of Biomass Pretreatment to Cost and Carbon Emissions: Case Study of Rice Straw and Pennisetum in Taiwan," Bioresource Technology, 108 285-294.

Clausen, L. R., Houbak, N. \& Elmegaard, B. (2010). "Techno-Economic Analysis of a Low CO2 Emission Dimethyl Ether (DME) Plant Based on Gasification of Torrefied Biomass," Energy, 35 4831-4842.

Coronella, C. J., Yan, W., Reza, M. T. \& Vasquez, V. R. (2012). "Method for Wet Torrefaction of a Biomass," Patent Application Number 20120110896, Publication Date 2012-05-10.

Couhert, C., Salvador, S. \& Commandre, J.M. (2009). "Impact of Torrefaction on Syngas Production from Wood," Fuel, 88 (11) 2286-2290.

Demirbas, A. (2008). "Biofuels Sources, Biofuel Policy, Biofuel Economy and Global Biofuel Projections," Energy Conversion and Management, 49 2106-2116.
Deng, J., Wang, G. J., Kuang, J.- H., Zhang, Y.L. \& Luo, Y.- H. (2009). "Pretreatment of Agriculture Residues for Co-Gasification via Torrefaction," Journal of Analytical and Applied Pyrolysis, 86 (2) 331-337.

Deutmeyer, M., Bradley, D., Hektor, B., Tumuluru, J. S., Hess, R., Nikolaisen, L. \& Wild, M. (2012). "Possible Effect of Torrefaction on Biomass Trade," IEA Bioenergy, Task:40 Sustainable International Bioenergy Trade. Retrieved at http://www.bioenergytrade.org/download s/t40-torrefaction-2012.pdf, 13th May 2013.

Dhungana, A., Basu, P. \& Dutta, A. (2012a). "Effects of Reactor Design on the Torrefaction of Biomass," Journal of Energy Resources Technology, 134 (4) 041801-811.

Dhungana, A. (2011). "Torrefaction of Biomass," Master Thesis, Dalhousie University, Department of Mechanical Engineering, Canada.

Doelle, H. W. (2012). "Biomass and Organic Waste Conversion to Food, Feed, Fuel, Fertilizer, Energy and Commodity Products," Biotechnology X. Encyclopedia of Life Support Systems (EOLSS). Retrieved at http://www.eolss.net/Sample-

Chapters/C17/E6-58-09-04.pdf, 28th April 2013.

Duncan, A., Pollard, A. \& Fellouah, H. (2013). "Torrefied, Spherical Biomass Pellets through the Use of Experimental Design," Applied Energy, 101 237-243.

Dutta, A. (2013). University of Guelph, Personal Communication, October 19, 2013.

ecoTech Energy Group (2010). "Torrefaction Technology," Retrieved at http://www.ecotechenergygroup.com/ind ex.php/alternative-energy, 7 th July 2012.

ECPI (2012). 'Dust Explosion and Fire: Torrefied Biomass Vs. Non-Torrefied Biomass,' Earth Care Products Incorporated. Retrieved at http://ecpisystems.com/documents/, 25th May 2013. 
Emsley, A. M. \& Stevens, G. C. (1994). "Review: Kinetics and Mechanisms of the Low-Temperature Degradation of Cellulose," Cellulose, 1 26-56.

Erlach, B., Harder, B. \& Tsatsaronis, G. (2012). "Combined Hydrothermal Carbonization and Gasification of Biomass with Carbon Capture," Energy, 45(1) 329338.

EUBIA (2007). 'Biomass Characteristics,' European Biomass Industry Association (EUBIA). Retrieved at http://www.eubia.org/115.0.html, 15th May 2012.

Felfli, F. F., Luengo, C. A., Suarez, J. A. \& Beaton, P. A. (2005). "Wood Briquette Torrefaction," Energy for Sustainable Development, 9 (3) 19-22.

Fick, G., Mirgaux, O., Neau, P. \& Patisson, F. (2012). 'Using Biomass for Pig Iron Production: A Technical Environmental and Economical Assessment,' Waste Biomass Valorisation, Springer.

Fisher, E. M., Dupont, C., Darvell, L. I., Commandre, J. M., Saddawi, A., Jones, J. M., Grateau, M., Nocquet, T. \& Salvador, S. (2012). "Combustion and Gasification Characteristics of Chars from Raw and Torrefied Biomass," Bioresource Technology, 119 157-165.

Foster, C. E., Martin, T. M. \& Pauly, M. (2010). "Comprehensive Compositional Analysis of Plant Cell Walls Lignocellulosic Biomass Part II: Carbohydrates," Journal of Visualized Experiments, 37. Retrieved at http://paulylab.berkeley.edu/Publications /JoVE_Protocol_1837.pdf, 27th February 2013.

Fullerton, D. G., Bruce, N. \& Gordon, S. B. (2008). "Indoor air Pollution from Biomass Fuel Smoke is a Major Health Concern in the Developing World," Transaction of the Royal Society of Tropical Medicine and Hygiene, 102(9) 843-851.
Funke, A. \& Zeigler, F. (2010). "Hydrothermal Carbonization of Biomass: A Summary and Discussion of Chemical Mechanisms for Process Engineering," Biofuel, Bioproducts and Biorefining, 4 (2) 160-177.

Ge, L., Zhang, Y., Wang, Z., Zhou, J. \& Cen, K. (2013). "Effects of Microwave Irradiation Treatment on Physicochemical Characteristics of Chinese Low-Rank Coals," Energy Conversion and Management, 71 84-91.

Gilbert, P., Ryu, C., Sharifi, V. \& Swithenbank, J. (2009). "Effect of Process Parameters on Pelletisation of Herbaceous Crops," Fuel, 88 (8) 1491-1497.

Giudicianni, P., Cardone, G. \& Ragucci, R. (2013). "Cellulose, Hemicellulose and Lignin Slow Steam Pyrolysis: Thermal Decomposition of Biomass Components Mixtures," Journal of Analytical and Applied Pyrolysis, 100 213-222.

Glaser, B., Haumaier, L., Guggenberger, G. \& Zech, W. (2001). "The 'Terra Preta' Phenomenon: A Model for Sustainable Agriculture in the Humid Tropics," Naturwissenschaften, 88 37-41.

Glaser, B., Lehmann, J. \& Zech, W. (2002). "Ameliorating Physical and Chemical Properties of Highly Weathered Soils in the Tropics with Charcoal - A Review," Biology and Fertility of Soils, 35 219-230.

Gonzalez-Fernandez, C., Sialve, B., Bernet, N. \& Steyer, J. P. (2012). "Thermal Pretreatment to Improve Methane Production of Scenedesmus Biomass," Biomass and Bioenergy, 40 105-111.

Guerrero, M., Ruiz, M. P., Millera, A., Alzueta, M. U. \& Bilbao, R. (2008). "Characterization of Biomass Chars Formed under Different Devolatization Conditions: Differences between Rice Husk and Eucalyptus," Energy and Fuels, 22 12751284. 
Gupta, R. B. \& Demirbas, A. (2010). Gasoline, Diesel, and Ethanol Biofuels from Grasses and Plants, Cambridge University Press, Technology and Engineering.

Harmsen, P. F. H., Huijgen, W. J. J., Lopez, L. M. B. \& Baker, R. R. C. (2010). Literature Review of Physical and Chemical Pretreatment Processes for Lignocellulosic Biomass, Energy Research Center of the Netherlands, ECN-E-10-013. Retrieved at http://www.ecn.nl/docs/library/report/2 010/e10013.pdf, 26th May 2012.

Henrich, E., Dinjus, E., Rumpel, S. \& Stahl, R. (2008). "A Two-Stage Pyrolysis/Gasification Process for Herbaceous Waste Biomass from Agriculture," Retrieved at http://s3.amazonaws.com/zanran_storage /www.fzk.de/ContentPages/849605316.p df, 1st May 2013.

Hoekman, S. K., Broch, A., Robbins, C., Zielinska, B. \& Felix, L. (2013). "Hydrothermal Carbonization of Selected Woody and Herbaceous Biomass Feedstock," Biomass Conversion and Biorefineries, 3 113-126.

Homan, W., Tjeerdsma, B., Beckers, E. \& Jorissen, A. (2012). "Structural and Other Properties of Modified Wood," Retrieved at http://woodwestwood.com/Researches/35-1.pdf, 30th April 2013.

Hoogwijk, M., Faaij, A., Eickhout, B., Vries, B. \& Turkenburg, W. (2005). "Potential of Biomass Energy out to 2100, for Four IPCC SRES Land-Use Scenarios," Biomass and Energy, 29 225-257.

Huang, Y. F., Chen, W. R., Chiueh, P. T., Kuan, W. H. \& Lo, S. L. (2012). "Microwave Torrefaction of Rice Straw and Pennisetum," Bioresource Technology, 123 1-7.

IEA (2009). "Energy Balance of the World: 2009," International Energy Agency. Retrieved at http://www.iea.org/stats/balancetable.asp ?COUNTRY_CODE=29, 15th May 2012.
IEO (2011). International energy outlook 2011. U. S. Energy Information Administration 2011. Retrieved at www.eia.gov/ieo/pdf/0484(2011).pdf, 24th October 2011.

IPCC (2000). Land use, Land-use change, and forestry. Watson, R.T., Noble, R., Bolin, B., Ravindranath, N.H., Verardo, D.J. \& Dokken, D.J. (eds.). 'Intergovernmental Panel on Climatic Change Special Report,' Cambridge, Cambridge University Press.

Jena, U., Vaidyanathan, N., Chinnasamy, S. \& Das, K. C. (2011). "Evaluation of Microalgae Cultivation Using Recovered Aqueous CoProduct from Thermochemical Liquefaction of Algal Biomass," Bioresource Technology, 102(3) 3380-3387.

Jones, J. M., Bridgeman, T. G., Dravell, L. I., Gudka, B., Saddawi, A. \& Williams, A. (2012). "Combustion Properties of Torrefied Willow Compared with Bituminous Coals," Fuel Processing Technology, 101 1-9.

Koh, M. P. \& Hoi, W. K. (2003). "Sustainable Biomass Production for Energy in Malaysia," Biomass and Bioenergy, 25 517529.

Kokko, L., Tolvanen, H., Hamalainen, K. \& Raiko, R. (2012). “Comparing the Energy Required for Fine Grinding Torrefied and Fast Heat-Treated Pine," Biomass and Bioenergy, 42 219-223.

Koppejan, J., Sokhansanj, S., Melin, S. \& Madrali, S. (2012). 'Status Overview of Torrefaction Technologies,' IEA Bioenergy Task 32 Report. International Energy Agency, France.

Kuai, N., Huang, W., Du, B., Yuan, J., Li, Z., Gan, Y. \& Tan, J. (2013). “Experiment-Based Investigations on the Effect of Ignition Energy on Dust Explosion Behaviors," Journal of Loss Prevention in the Process Industries, 26 869-877. 
Lamsal, B., Yoo, J., Brijwani, K. \& Alavi, S. (2010). "Extrusion as a Thermo-Mechanical Pretreatment for Lignocellulosic Ethanol," Biomass and Bioenergy, 34 (12) 1703-1710.

Lehmann, J., Gaunt, J. \& Rondon, M. (2006). "Bio-Char Sequestration in Terrestrial Ecosystems - A Review," Mitigation and Adaptation Strategies for Global Change, 11 403-427.

Li, H., Liu, X., Legros, R., Bi, X. T., Lim, C. J. \& Sokhansanj, S. (2012). "Pelletization of Torrefied Sawdust and Properties of Torrefied Pellets," Applied Energy, 93 680685.

Li, Q., Lin, B., Dai, H. \& Zhao, S. (2012a). "Explosion Characteristics of $\mathrm{H} 2 / \mathrm{CH} 4 /$ Air and CH4/Coal Dust/Air Mixtures," Powder Technology, 229 222-228.

Libra, J. A., Ro, K. S., Kammann, C., Funke, A., Berge, N. D., Neubauer, Y. et al. (2011). "Hydrothermal Carbonization of Biomass Residuals: A Comparative Review of the Chemistry, Process, and Applications of Wet and Dry Pyrolysis," Future Science Group, Biofuels, 2 (1) 89-124.

Lipinsky, E. S., Arcate, J. R. \& Reed T. B. (2002). "Enhanced Wood Fuels via. Torrefaction," Fuel Chemistry Division Preprints, 47 (1) 408-410.

Liu, Q., Bai, C., Li, X., Jiang, L. \& Dai, W. (2010). "Coal Dust/Air Explosions in a Large-Scale Tube," Fuel, 89 329-335.

Liu, Z., Quek, A., Hoekman, S. K. \& Balasubramanian, R. (2013). "Production of Solid Biochar Fuel from Waste Biomass by Hydrothermal Carbonization," Fuel, 103 943-949.

Lu, K.- M., Lee, W.- J., Chen, W.- H., Liu, S.- H. \& Lin, T.- C. (2012). "Torrefaction and Low Temperature Carbonization of Oil Palm Fiber and Eucalyptus in nitrogen and Air Atmospheres," Bioresources Technology, 123 98-105.
Lynman, J. G., Coronella, C. J., Yan, W., Reza, M. T. \& Vasquez, V. R. (2011). "Acetic Acid and Lithium Chloride Effects on the Hydrothermal Carbonization of Lignocellulosic Biomass," Bioresource Technology, 102 6192-6199.

Mani, T., Mahinpey, N. \& Murugan, P. (2011). "Reaction Kinetics and Mass Transfer Studies of Biomass Char Gasification with CO2," Chemical Engineering Science, 66 36-41.

McKendry, P. (2002). “Energy Production from Biomass (Part 1): Overview of Biomass," Bioresource Technology, 83 3746.

Medic, D., Darr, M., Shah, A., Potter, B. \& Zimmerman, J. (2011). "Effects of Torrefaction Process Parameters on Biomass Feedstock Upgrading," Fuel, 91 (1) 147-154.

Medina, C. H., Phylaktou, H. N.,. Sattar, H., Andrews, G. E. \& Gibbs, B. M. (2013). "The Development of an Experimental Method for the Determination of the Minimum Explosible Concentration of Biomass Powders," Biomass and Bioenergy, 53 95104.

Melin, S. (2011). "Torrefied Wood: A New Emerging Energy Carrier," Presentation, Presented on Clean Coal Power Coalition, Wood Pellet Association of Canada. http://www.pellet.org/linked/2011-03 09\%20сcрс\%20presentation\%20(2).pdf, 20th December 2013.

Melkior, T., Jacob, S., Gerbaud, G., Hediger, S., Pape, L. L., Bonnefios, L. \& Bardet, M. (2011). "NMR Analysis of the Transformation of Wood Constituents by Torrefaction," Fuel, 92 (1) 271-280.

Meng, J., Park, J., Tilotta, D. \& Park, S. (2012). "The Effect of Torrefaction on the Chemistry of Fast Pyrolysis Bio-Oil," Bioresource Technology, 111 439-446. 
Moghtaderi, B. (2006). "The State-Of-TheArt in Pyrolysis Modeling of Lignocellulosic Solid Fuels," Fire and Materials, 30 1-34.

Na, B.- I., Kim, Y.- H., Lim, W.- S., Lee, S.- M., Lee, H.- W. \& Lee, J.- W. (2013). "Torrefaction of Oil Palm Mesocarp Fiber and Their Effect on Pelletizing," Biomass and Bioenergy, 52 159-165.

NSWDPI (2013). "Biochar," Primary Industries Science and Research, NSW Department of Primary Industries, Australia. Retrieved at http://www.dpi.nsw.gov.au/research/topi cs/biochar, 27 September 2013.

Oliveira, I., Blohse, D. \& Ramke, H.- G. (2013). "Hydrothermal Carbonization of Agriculture Residues," Bioresource Technology, Accepted Manuscript.

Pach, M., Zanzi, R. \& Bjornbom, E. (2002). "Torrefied Biomass a Substitute for Wood and Charcoal," 6th Asia-Pacific International Symposium on Combustion and Energy Utilization, 20th - 22nd May 2002, Kuala Lumpur.

Pandey, M. P. \& Kim, C. S. (2011). "Lignin Depolymerization and Conversion: A Review of Thermochemical Methods," Chemical Engineering Technology, 34 2941.

Pasangulapati, V., Ramachandriya, K. D., Kumar, A., Wilkins, M. R., Jones, C. L. \& Huhnke, R. L. (2012). "Effects of Cellulose, Hemicellulose and Lignin on Thermochemical Conversion Characteristics of the Selected Biomass," Bioresource Technology, 114 663-669.

PCSB (2011). 'Commercialization Summary,' PCS Biofuels Incorporated, Presentation slides, June 2011, Not Published.

PCSB (2013). "The PCS Biofuel Technology," PCS Biofuels, Retrieved at http://www.pcsbiofuels.com/technology.p hp\#htp, 29th May 2013.
Peng, J. H., Bi, H. T., Sokhansanj, S. \& Lim, J. C. (2012). "A Study of Particle Size Effect on Biomass Torrefaction and Densification," Energy and Fuels, 26 3826-3839.

Pentananunt, R., Rahman, A. N. M. M. \& Bhattacharya, S. C. (1990). "Upgrading of Biomass by Means of Torrefaction," Energy, 15 (12) 1175-1179.

Phanphanich, M. \& Mani, S. (2011). "Impact of Torrefaction on the Grindability and Fuel Characteristics of Forest Biomass," Bioresource Technology, 102 1246-1253.

Pirraglia, A., Gonalez, R., Denig, J. \& Saloni, D. (2013). "Technical and Economic Modeling for the Production of Torrefied Lignocellulosic Biomass for the U. S. Densified Fuel Industry," Bioenergy Resources, 6 263-275.

Prando, D., Patuzzi, F., Baggio, P. \& Baratieri, M. (2013). "CHP Gasification System Fed by Torrefied Biomass: Assessment of the Energy Performance," Waste Biomass Valorization.

Prins, M. J., Ptasninski, K. J. \& Janssen, F. J. J. G. (2006). "More Efficient Biomass Gasification via Torrefaction," Energy, 31 (15) 3458-347. DOI: http://dx.doi.org/10.1016/j.energy.2006.0 3.008

Prins, M. J., Ptasinski, K. J. \& Janssen, F. J. J. G. (2006a). "Torrefaction of Wood Part 2. Analysis of Products," Journal of Analytical and Applied Pyrolysis, 77 35-40.

Prins, M. J., Ptasinski, K. J. \& Janssen, F. J. J. G. (2007). "From Coal to Biomass Gasification: Comparison of Thermodynamic Efficiency," Energy, 32(7) 1248-1259.

Ptasinski, K. J. (2008), “Thermodynamic Efficiency of Biomass Gasification and Biofuels Conversion," Biofuels Bioproducts and Biorefining, 2 239-253. 
Ratte, J., Fardet, E., Mateos, D. \& Hery, J.- S. (2011). "Mathematical Modeling of a Continuous Biomass Torrefaction Reactor: TORSPYDTM Column," Biomass and Bioenergy, 35 3481-3495.

Raut, M. K., Basu, P. \& Acharya, B. (2013). 'Effect of Torrefaction Pretreatment on the Gasification of Biomass,' CSChE Conference, 20-23 October, Fredericton, 2013

Rautiainen, M., Havimo, M. \& Gruduls, K. (2012). "Biocoal Production, Properties and Uses," Baltic Bioenergy and Industrial Charcoal, Report 1/2012, Production and Logistics.

Raveendran, K., Ganesh, A. \& Khilar, K. C. (1996). "Pyrolysis Characteristics of Biomass and Biomass Components," Fuel, 75(8) 987-998.

Ren, S., Lei, H., Wang, L., Bu, Q., Wei, Y., Liang, J., Liu, Y. et al. (2012). "Microwave Torrefaction of Douglas Fir Sawdust Pellets," Energy Fuels, 26 5936-5943.

Repellin, V., Govin, A., Rolland, M. \& Guyonment, R. (2010). "Energy Required for Fine Grinding of Torrefied Wood," Biomass and Bioenergy, 34 923-930.

Roman, S., Nabais, J. M. V., Laginhas, C., Ladesma, B. \& Gonzalez, J. F. (2012). "Hydrothermal Carbonization as an Effective Way of Densifying the Energy Content of Biomass," Fuel Processing Technology, 103 78-83.

Rousset, P., Davrieux, F., Macedo, L. \& Perre, P. (2011). "Characterization of the Torrefaction of Beech Wood Using NIRS: Combined Effects of Temperature and Duration," Biomass and Bioenergy, 35 12191226.

Rousset, P., Macedo, L., Commandre, J.- M. \& Moreira, A. (2012). "Biomass Torrefaction under Different Oxygen Concentrations and Its Effect on the Composition of the Solid By-Products," Journal of Analytical and Applied Pyrolysis, 96 86-91.
Rowell, R. M. (2005). Handbook of Wood Chemistry and Wood Composites, Taylor and Francis, CRC press, USA.

Scheller, H. V. \& Ulvskov, P. (2010), "Hemicelluloses: Annual Review of Plant Biology," Plant Biology, 61 263-289.

Schlesinger, W. H. \& Lichter, J. (2001), "Limited Carbon Storage in Soil and Litter of Experimental Forest Plots under Increased Atmospheric C02," Nature, 411 466-469.

Shafizadeh, F. (1985), "Pyrolytic Reactions and Products of Biomass," in: Prins, M. J., Ptasinski, K. J., Janssen, F. J. J. G., 2006. Torrefaction of wood: Part 1. Weight Loss Kinetics, Journal of Applied Pyrolysis, 77 2834.

Shang, L., Nielsen, N. P. K., Dahl, J., Stelte, W., Ahrenfeldt, J., Holm, J. K., Thomsen, T. \& Henriksen, U., B. (2012), "Quality Effect Caused by Torrefaction of Pellets Made from Scots Pine," Fuel Processing Technology, 101 23-28.

Shoulaifar, T. K., DeMartini. N., Ivaska, A., Fardim, P. \& Hupa, M. (2012). "Measuring the Concentration of Carboxylic Acid Groups in Torrefied Spruce Wood," Bioresource Technology, 123 338-343.

Sorum, L., Groni, M. G. \& Hustad, J. E. (2001). "Pyrolysis Characteristics and Kinetics of Municipal Solid Wastes," Fuel, 80 (9) 1217-1227.

Stelte, W., Clemons, C., Holms, J. K., Sanadi, A. R., Ahrenfeldt, J., Shang, L., \& Henriksen, U. B. (2011). "Pelletizing Properties of Torrefied Spruce," Biomass and Bioenergy, 35 (11) 4690-4698.

Stephan, C. R. (2012). "Coal Dust Explosion Hazards," Mine Safety and Health Administration Pittsburgh, Pennsylvania, U. S. A. Retrieved at http://www.msha.gov/SandHINFO/TECHR PT/PandT/COALDUST.pdf, 31st May 2013. 
Sule, I.O. (2012). 'Torrefaction Behavior of Agricultural Biomass,' M.Sc Thesis, School of Engineering, University of Guelph, Ontario, Canada.

Sun, Y. \& Cheng, J. (2002). "Hydrolysis of Lignocellulosic Materials for Ethanol Production: A Review," Bioresource Technology, 83 1-11.

Sundqvist, B. (2004). "Color Changes and Acid Formation in Wood during Heating," Doctoral Thesis, Division of Wood and Material Science, Lulea University of Technology. Retrieved at http://epubl.luth.se/1402-

1544/2004/10/LTU-DT-0410-SE.pdf, 29th April 2013.

Svoboda, K., Pohorely, M., Hartman, M. \& Martinec, J. (2009). "Pretreatment and Feeding of Biomass for Pressurized Entrained Flow Gasification," Fuel Processing Technology, 90 629-635.

Tomme, P., Warren, R. A. J., \& Gilkes, N. R. (1995). Cellulose Hydrolysis by Bacteria and Fungi, In: Advances in Microbial Physiology, Vol. 37, Poole, R. K., pp. 1-81, Academic Press, ISBN 0-12-027737-9, London, UK.

Topell (2012). 'Torrefied Biomass: Advantages over Untreated Biomass,' Topell Energy, Updated in 11th June 2012. Retrieved at http://www.topellenergy.com/product/tor refied-biomass/, 13th May 2013.

Torrent, J. (2011). 'Test Report on Characterization of Flammable Solids, Torrefied Wood Fuel,' Laboratorio Official J.M. Madariaga, (October 2011), Not published.

Torres, S. S., Jomaa, W., Marc, F. \& Puiggali, J.- R. (2010). "Causes of Color Changes in Wood during Drying," Forestry Studies in China.

Tremel, A., Spemann, J., Herrmann, M., Erlach, B. \& Spliethoff, H. (2012). "Entrained Flow Gasification of Biocoal from Hydrothermal Carbonization," Fuel, 102 396-403.
Tumuluru, J. S., Sokhansanj, S., Hess, J. R., Wright, C. T. \& Boardman, R. D. (2011). "A Review on Biomass Torrefaction Process and Product Properties for Energy Applications," Industrial Biotechnology, 7 384-401.

Tumuluru, J. S., Sokhansanj, S., Hess, J. R., Wright, C. T. \& Kremer, T. (2012). "GC Analysis of Volatiles and Other Products from Biomass Torrefaction Process," Advanced Gas Chromatography-Progress in Agricultural, Biomedical and Industrial Applications. Retrieved at http://cdn.intechopen.com/pdfs/32823/In Tech-

Gc_analysis_of_volatiles_and_other_product s_from_biomass_torrefaction_process.pdf, 27th April 2013.

Uemura, Y., Omar, W. N., Tsutsui, T. \& Yusup, S. B. (2011). "Torrefaction of Oil Palm Wastes," Fuel, 90 2585-2591.

Uemura, Y., Omar, W., Othman, N. A., Yusup, S. \& Tsutsui, T. (2013). "Torrefaction of Oil Palm EFB in the Presence of Oxygen," Fuel, 103 156-160.

Van der Stelt, M. J. C., Gerhauser, H., Kiel, J. H. A. \& Ptasinski, K. J. (2011). "Biomass Upgrading by Torrefaction for the Production of Biofuels: A Review," Biomass and Bioenergy, 35 3748-3762.

Van de Weerdhof, M. W. (2010). 'Modeling of the Pyrolysis Process of Biomass Particles,' Master Thesis, WVT 2010.07, Eindhoven University of Technology, Department of Mechanical Engineering, Netherlands.

Vanholme, R., Demedts, B., Morreel, K., Ralph, J., \& Boerjan, W. (2010). "Lignin Biosynthesis and Structure," Plant Physiology, 153(3) 895-905.

Wang, C., Peng, J., Li, H., Bi, X. T., Legros, R., Lim, C. J. \& Sokhansanj, S. (2012). "Oxidative Torrefaction of Biomass Residues and Densification of Torrefied Sawdust to Pellets," Bioresource Technology, 127 318-325. 
Wang, G. J., Luo, Y. H., Deng, J., Kuang, J. H. \& Zhang, Y. L. (2011). "Pretreatment of Biomass Torrefaction," Special Topic: Bioenergy, Energy Science and Technology, Chinese Science Bulletin, 56 1442-1448.

Wang, M. J., Huang, Y. F., Chiueh, P. T., Kuan, W. H. \& Lo, S. L. (2012a). "MicrowaveInduced Torrefaction of Rice Husk and Sugarcane Residues," Energy, 37 177-184.

Wannapeera, J., Fungtammasan, B., \& Worasuwannarak, N. (2011). "Effects of Temperature and Holding Time during Torrefaction on the Pyrolysis Behaviors of Woody Biomass," Journal of Analytical and Applied Pyrolysis, 92(1) 99-105.

Wannapeera, J. \& Worsauwannarak, N. (2012). "Upgrading Woody Biomass by Torrefaction under Pressure," Journal of Analytical and Applied Pyrolysis, 96 173180.

White, R. H. \& Dietenberger, M. A. (2001). "Wood Products: Thermal Degradation and Fire," In Torres, S. S., Jomaa, W., Marc, F., Puiggali, J. R. (2010). "Causes of Color Changes in Wood during Drying," Forestry Studies in China, 12(4 167-175.

Wingreini, A., Galbe, M., Roslander, C., Rudolf, A., \& Zacchi, G. (2005). "Effect of Reduction in Yeast and Enzyme Concentrations in a SimultaneousSaccharification-and-Fermentation- Based Bioethanol Process," Biotechnology for Fuels and Chemicals, 26 ABAB Symposium 2005, 485-499.
Wu, K. T., Tsai, C. J., Chen, C. S. \& Chen, H. W. (2012). "The Characteristics of Torrefied Microalgae," Applied Energy, 100 52-57.

Yan, W., Acharjee, T. C., Coronella, C. J. \& Vasquez, V. R. (2009). "Thermal Pretreatment of Lignocellulosic Biomass," Environmental Progress and Sustainable Energy, 28 (3) 435-440.

Yan, W., Hastings, J. T., Acharjee, T. C., Coronella, C. J. \& Vasquez, V. R. (2010). "Mass and Energy Balance of Wet Torrefaction of Lignocellulosic Biomass," Energy and Fuels, 24 4738-4742.

Yang, H., Yan, R., Chen, H., Lee, D. H. \& Zheng C. (2007). "Characteristics of Hemicellulose, Cellulose and Lignin Pyrolysis," Fuel, 86 1781-1788.

Yusup, S., Ahmad, M. M., Uemura, Y., Ali, R. M., Azmi, A. S., Mohamad, M. F. \& Lay, S. L. (2013). "Pre-treatment of Malaysian Agricultural Wastes towards Biofuel Production," Book Chapter 17. Pretreatment Techniques for Biofuels and Biorefineries, Green Energy and Technology.

Zheng, Y., Pan, Z. \& Zhang, R. (2009). "Overview of Biomass Pretreatment for Cellulosic Ethanol Production," International Journal of Agriculture and Biological Engineering, 2(3) 51-66. 